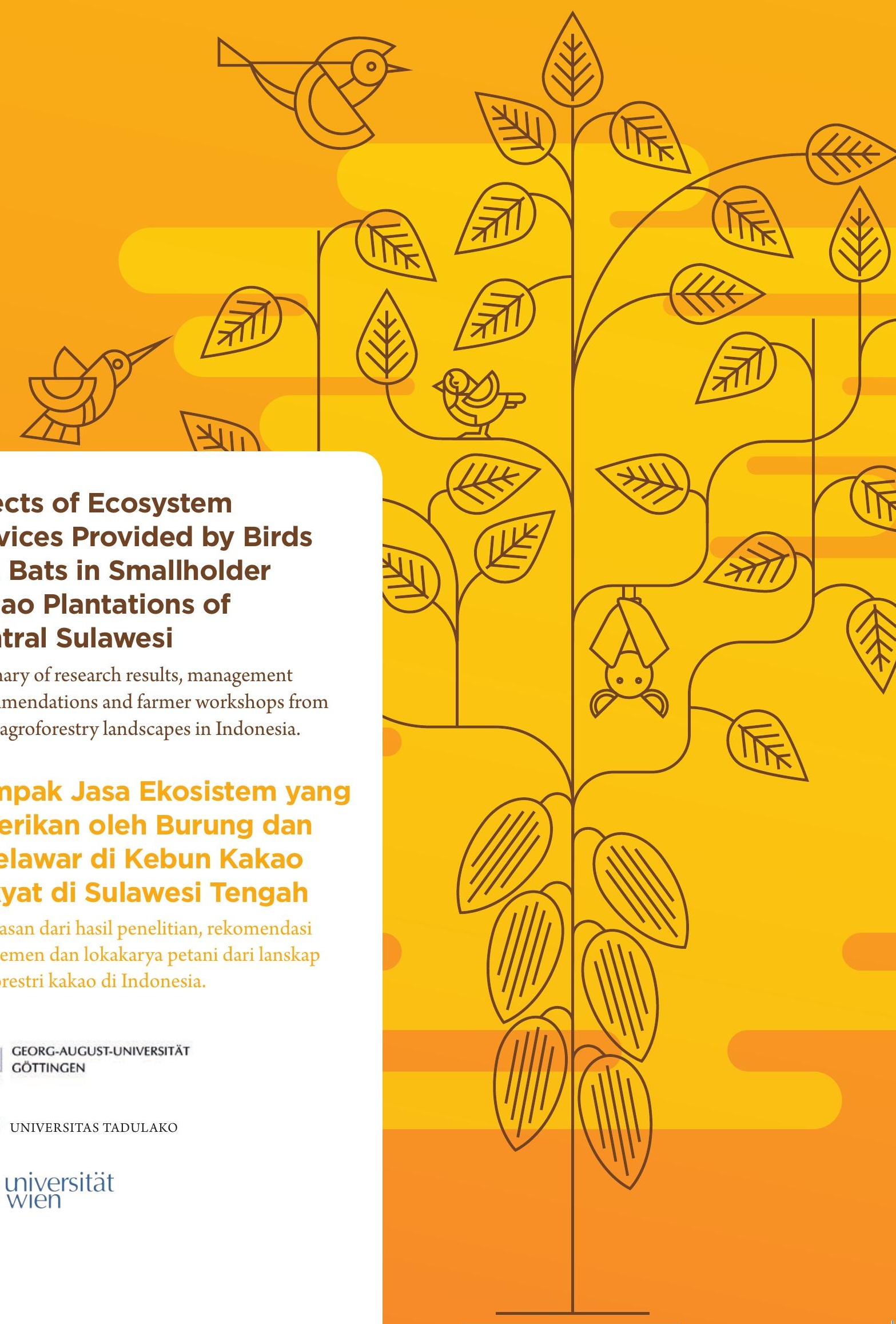

Effects of Ecosystem Services Provided by Birds and Bats in Smallholder Cacao Plantations of Central Sulawesi

Summary of research results, management recommendations and farmer workshops from cacao agroforestry landscapes in Indonesia.

Dampak Jasa Ekosistem yang Diberikan oleh Burung dan Kelelawar di Kebun Kakao Rakyat di Sulawesi Tengah Ringkasan dari hasil penelitian, rekomendasi manajemen dan lokakarya petani dari lanskap agroforestri kakao di Indonesia.

(a)

GEORG-AUGUST-UNIVERSITÄT GÖTINGEN

universität (2), wien 

Bea Maas et al

Effects of Ecosystem Services Provided by Birds and Bats in Smallholder Cacao Plantations of Central Sulawesi

This work is licensed under a Creative Commons Attribution-ShareAlike 4.0 International License. 


\title{
Effects of Ecosystem Services Provided by Birds and Bats in Smallholder Cacao Plantations of Central Sulawesi
}

Summary of research results, management recommendations and farmer workshops from cacao agroforestry landscapes in Indonesia.

\section{Dampak Jasa Ekosistem yang Diberikan oleh Burung dan Kelelawar di Kebun Kakao Rakyat di Sulawesi Tengah}

Ringkasan dari hasil penelitian, rekomendasi manajemen dan lokakarya petani dari lanskap agroforestri kakao di Indonesia.

\section{First Edition \\ Edisi Pertama}

\author{
AUTHORS / PENULIS: \\ Bea Maas \\ Agroecology - University of Göttingen, Germany \\ Conservation Biology, Vegetation Ecology and Landscape Ecology - \\ University of Vienna, Austria \\ Teja Tscharntke \\ Agroecology - University of Göttingen, Germany \\ Aiyen Tjoa, Shahabuddin Saleh, Nur Edy, \\ Alam Anshary, Mahfudz, Muhammad Basir \\ Agrotechnology - Agriculture Faculty of Tadulako University, Indonesia
}

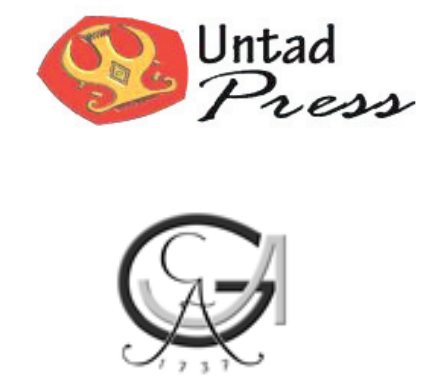

Göttingen University Press 


\section{Effects of Ecosystem Services Provided}

by Birds and Bats in Smallholder

Cacao Plantations of Central Sulawesi

Summary of research results, management recommendations and farmer workshops from cacao agroforestry landscapes in Indonesia.

Copyright 2017 Bea Maas et al. Published by UNTAD press, 2017 Published by Göttingen University Press, 2018

Authors:

Bea Maas, Teja Tscharntke

Aiyen Tjoa, Shahabuddin Saleh, Nur Edy, Alam Anshary, Mahfudz, Muhammad Basir

Layout and cover design: Dimas Aryo (arkea.id)

ISBN 978-602-6619-39-6

ISBN 978-3-86395-352-2

DOI: https://doi.org/10.17875/gup2018-1085

xii \& 106 pages; $17.6 \mathrm{~cm} \mathrm{x} 25 \mathrm{~cm}$

This book is printed under collaborative work between Georg August University of Gőttingen, Germany, Tadulako University, Indonesia, and University of Vienna, Austria

This work is protected by German Intellectual Property Right Law.

It is also available as an Open Access version through the publisher's homepage and the Göttingen University Catalogue (GUK) at the Göttingen State and University Library (http://www.sub.uni-goettingen.de).

The license terms of the online version apply. 


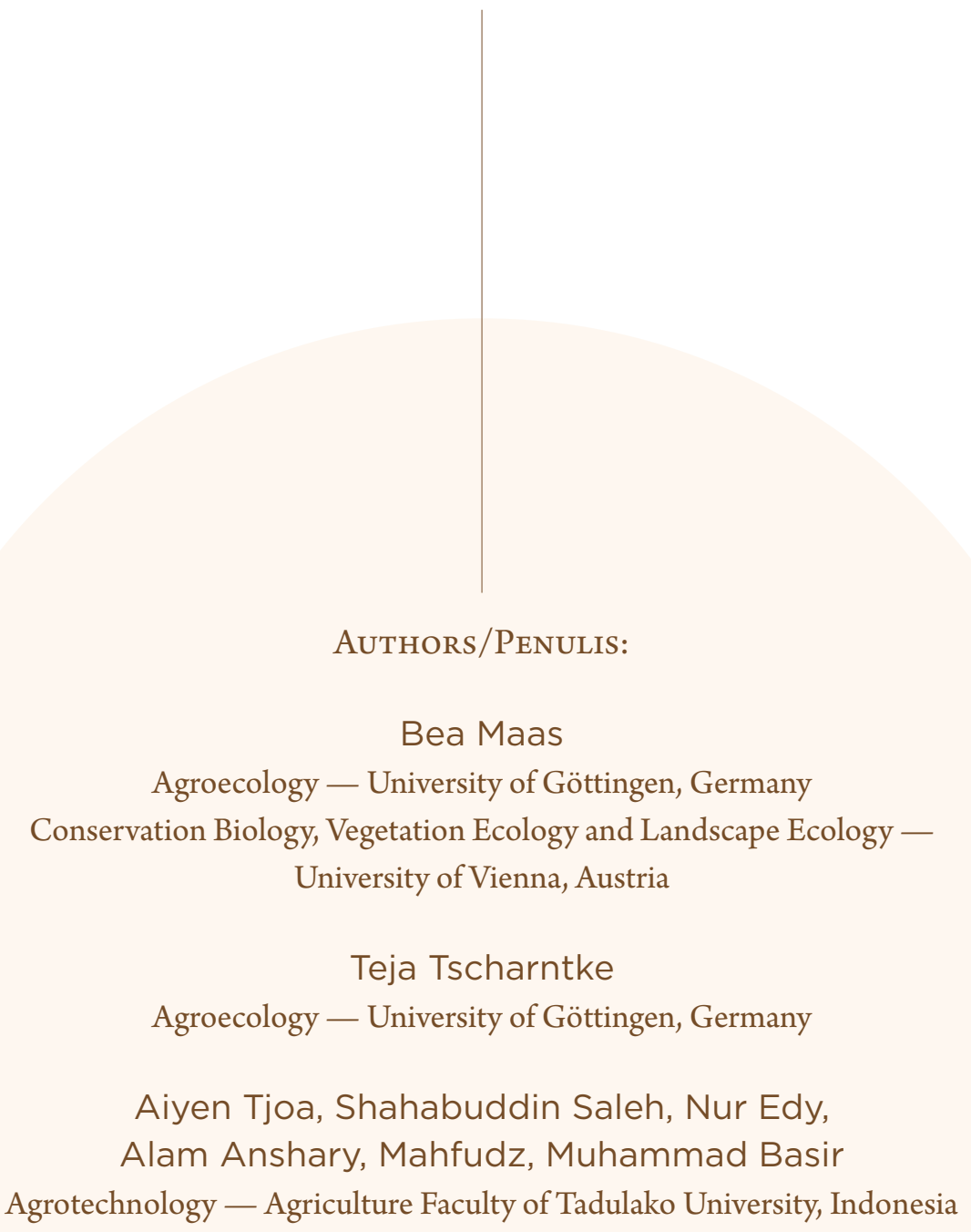




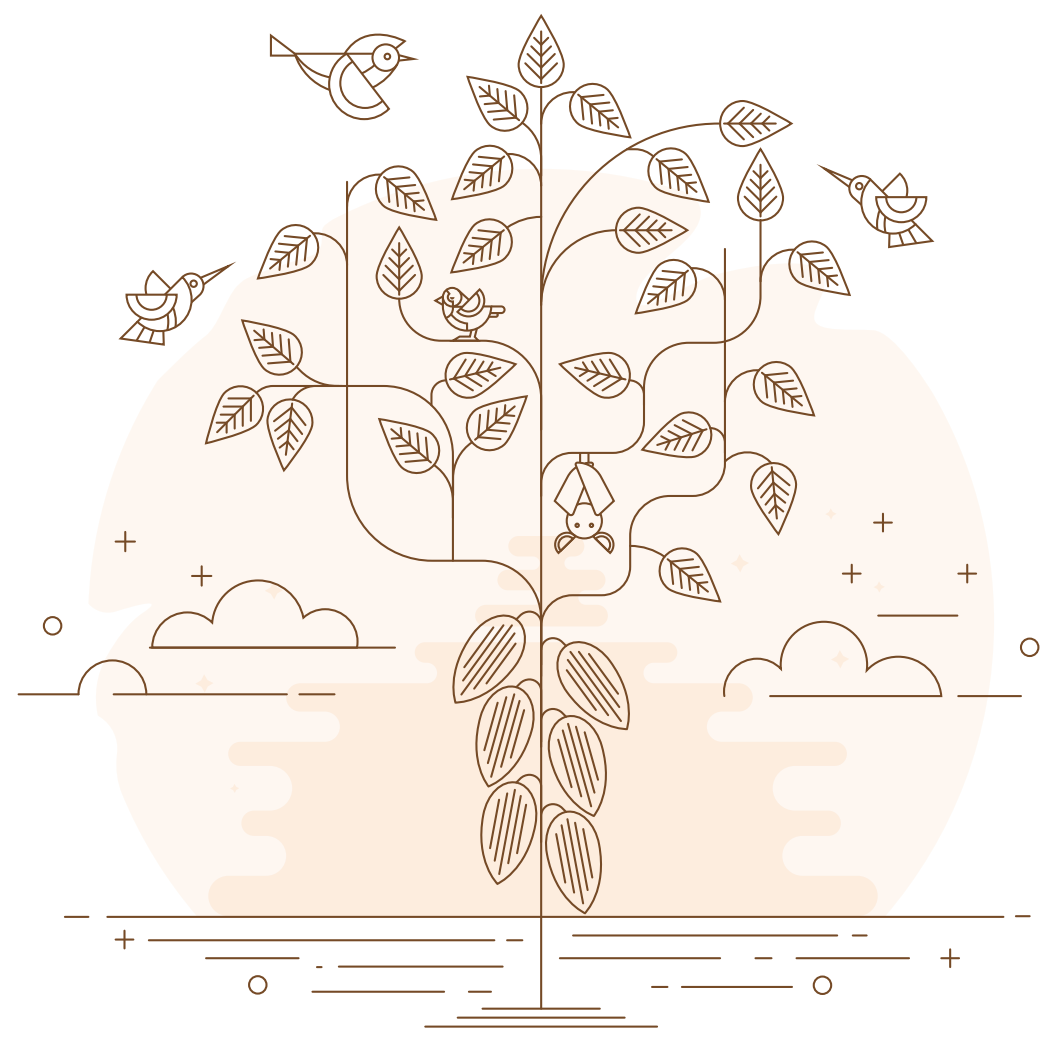

The illustrations in this book are composed of photographs, graphical illustrations and figures from scientific publications related to the work of the authors and their co-authors. The source and credits of the respective illustrations are provided in the figure captions of this booklet and indicate individual copy rights.

Ilustrasi dalam buku ini terdiri dari foto, ilustrasi grafis dan gambar dari publikasi ilmiah yang dihasilkan oleh penulis utama dan pendamping. Untuk mengutip ilustrasi yang terdapat pada buku ini, sumber hak ciptanya tertera pada setiap ilustrasi. 

$\mathrm{E}$ cological research on ecosystem services in agricultural landscapes has greatly improved our understanding of biodiversity impacts on agricultural productivity, sustainability and human well-being. As a part of this scientific field, the integrated research collaboration between Tadulako University and Göttingen University on ecosystem services in smallholder cacao plantations in Central Sulawesi contributed to a comprehensive understanding of the relationships between biodiversity and agricultural landscape management in tropical land use systems since the year 2000. Our recent research on ecosystem services by birds and bats in cacao agroforestry landscapes of Central Sulawesi was accompanied by a close cooperation and continuous knowledge transfer with local farmers and stakeholders in Central Sulawesi. As a result of this cooperation, we proudly present the first edition of a bilingual book on the results of our research and associated cooperation, entitled: "Effects of Ecosystem Services Provided by Birds and Bats in Smallholder Cacao Plantations of Central Sulawesi”.
$\mathrm{P}$ enelitian ekologis mengenai jasa ekosistem di lanskap pertanian telah sangat meningkatkan pemahaman kita tentang dampak keragaman hayati pada produktivitas pertanian, keberlanjutan dan kesejahteraan manusia. Sebagai bagian dari bidang ilmiah ini, penelitian kolaborasi terintegrasi antara Universitas Tadulako dan Universitas Göttingen tentang jasa ekosistem di perkebunan kakao rakyat di Sulawesi Tengah berkontribusi pada pemahaman yang komprehensif tentang hubungan antara keragaman hayati dan manajemen lanskap pertanian di sistem penggunaan lahan tropis sejak tahun 2000. Penelitian terkini kami tentang jasa ekosistem oleh burung dan kelelawar di lanskap agroforestri kakao Sulawesi Tengah diiringi dengan kerjasama yang erat dan transfer pengetahuan secara kontinu kepada petani lokal dan pemangku kepentingan di Sulawesi Tengah. Sebagai hasil dari kerjasama ini, kami dengan bangga mempersembahkan edisi pertama buku dwibahasa berisi hasil penelitian dan kerja sama kami yang berjudul “Dampak Jasa Ekosistem yang Diberikan Oleh Burung dan Kelelawar di Perkebunan Kakao Rakyat di Sulawesi Tengah”. 
This book results from the close cooperation of the leading researcher and first author, Dr. Bea Maas, and the co-authors with local cacao farmers in the research area during field work for her doctoral thesis, but also provide an overview of the results from the long-standing research partnership between Tadulako University and Göttingen University. It is designed to translate and communicate scientific information and research results on ecosystem services and associated benefits provided by birds and bats in smallholder cacao plantations rather than a practical solution for farmers in managing their farms.

This book is based on close and multi-year communication between ecologists and local cacao farmers and can therefore serve as a valuable tool to build a bridge of communications between farmers and scientists about ecosystems, biodiversity and land use strategies. As described in the book, birds and bats can make an economically beneficial contribution to cacao yield in Central Sulawesi and might therefore represent a valuable alternative to intensive farming practices, which impair the health and sustainability of cacao agroforestry systems. Thus, the findings and results presented in this book can help farmers to consider more biodiversity-friendly practices in the management of their farms.
Buku ini merupakan hasil kerjasama yang erat antara peneliti utama dan penulis pertama, Dr. Bea Maas, dan para penulis pendamping dengan petani kakao lokal di daerah penelitian selama penyelesaian disertasi S3. Tidak hanya itu, buku ini juga memberikan gambaran umum hasil kemitraan penelitian yang panjang antara Universitas Tadulako dan Universitas Göttingen. Buku ini dirancang untuk menerjemahkan dan menyampaikan informasi ilmiah dan hasil penelitian tentang jasa ekosistem dan manfaat terkait yang diberikan oleh burung dan kelelawar di perkebunan kakao rakyat, bukan sebagai sebuah solusi praktis bagi petani dalam mengelola perkebunan kakao mereka.

Buku ini didasarkan pada komunikasi yang erat selama bertahun-tahun antara para ekologis dan petani kakao lokal dan dengan demikian menjadi alat yang berharga untuk membangun jembatan komunikasi antara petani dan ilmuwan tentang ekosistem, keragaman hayati dan strategi penggunaan lahan. Seperti dijelaskan dalam buku ini, burung dan kelelawar dapat memberi kontribusi ekonomi yang bermanfaat untuk hasil panen kakao di Sulawesi Tengah. Dengan demikian, hal tersebut mungkin merupakan alternatif yang berharga untuk praktik pertanian intensif yang merusak kesehatan dan keberlanjutan sistem kakao agroforestri. Oleh karena itu, temuan dan hasil yang disajikan dalam buku ini dapat membantu petani untuk mempertimbangkan praktik yang lebih ramah pada keragaman hayati dalam manajemen perkebunan mereka. 
We consider this book as a good step to improve the collaboration of farmers and scientists as well as the application of scientific knowledge in agricultural practice. It is written in English and Indonesian to invite more readers and to bridge the gap between people having a command of only either Indonesian or English.

Tadulako University as well as Göttingen University highly acknowledges the research team behind this publication and our long-term partnership with Göttingen University. We hope for a productive and fruitful cooperation also in the future and for even more scientific footprints that will improve sustainable agricultural production and the health of ecosystems.

Prof. Dr. Muh. Basir Cyio

Rector of Tadulako University, Indonesia

Prof. Dr. Teja Tscharntke

Agroecology Group -

Göttingen University, Germany
Kami menganggap buku ini sebagai langkah yang baik untuk meningkatkan kerja sama petani dan ilmuwan serta penerapan pengetahuan ilmiah dalam praktik pertanian. Buku ini ditulis dalam bahasa Inggris dan Indonesia untuk mengundang lebih banyak pembaca dan untuk menjembatani kesenjangan antara orang yang hanya memiliki kemampuan bahasa Indonesia atau Bahasa Inggris saja.

Universitas Tadulako serta Universitas Göttingen memberi penghargaan setinggi-tingginya pada tim peneliti di balik publikasi ini dan kemitraan jangka panjang antara Universitas Tadulako dengan Universitas Göttingen. Kami mengharapkan kerjasama yang lebih produktif dan bermanfaat di masa depan dan lebih banyak jejak ilmiah yang akan meningkatkan produksi pertanian berkelanjutan dan kesehatan ekosistem.

Prof. Dr. Muh. Basir Cyio

Rektor Universitas Tadulako, Indonesia

Prof. Dr. Teja Tscharntke

Kelompok Agroekologi -

Universitas Göttingen, Jerman 


$$
\begin{aligned}
& \text { table of } \\
& \text { contents }
\end{aligned}
$$

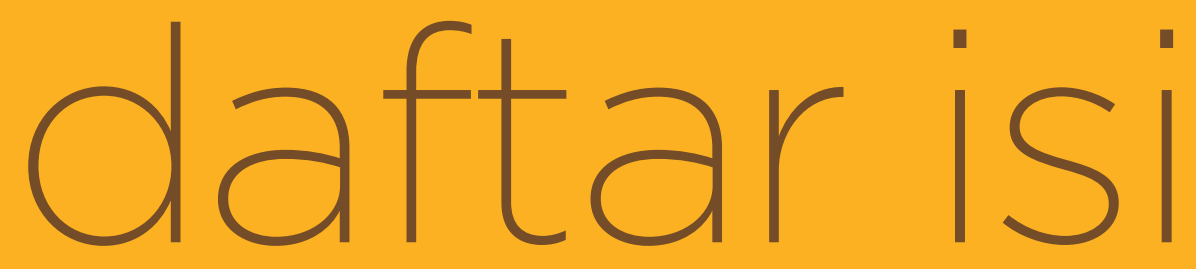


Foreword

Table of Content

01. Introduction

02. About the Research Project

03. Study Area and Selected Study Sites

04. Main Experiment: Exclosure of Birds and Bats

05. Research Questions

06. What Was Investigated During Our Research? 25

07. Research Results $\quad 35$

08. Conclusions and Management Recommendations 47

09. Relevance of the Project $\quad 53$

10. Cacao Farmer Workshop and Discussion of Results 57

11. Open Discussions and Response From Cacao Farmers 61

12. Information About Major Cacao Diseases and Their Management (Indonesian)

13. Explanation of Important Key Words of This Book (Indonesian) 79

14. Publication List (2002-2015) - Research in Sulawesi 83

15. Cacao Research at the Agriculture Faculty of Tadulako University 93

16. Acknowledgements 97

$\begin{array}{lr}\text { 17. References } & 103\end{array}$

Kata Pengantar vii

Daftar Isi $\quad$ xi

01. Pendahuluan 1

02. Tentang Kegiatan Penelitian Ini 9

03. Lokasi dan Petak Penelitian yang Terpilih 15

04. Eksperimen Utama: Eksklusi Burung dan Kelelawar 19

05. Pertanyaan Penelitian $\quad 23$

06. Apa Saja yang Diinvestigasi Selama Penelitian Kami? 25

07. Hasil Penelitian $\quad 35$

08. Kesimpulan dan Rekomendasi Manajemen 47

09. Relevansi Proyek $\quad 53$

10. Lokakarya Petani Kakao dan Diskusi Hasil Penelitian 57

11. Diskusi Terbuka dan Tanggapan Petani Kakao 61

12. Informasi Penyakit Utama Kakao dan Manajemennya 73

13. Penjelasan Kata Penting pada Buku Ini 79

14. Daftar Publikasi (2002-2015) - Penelitian di Sulawesi 83

15. Penelitian Kakao di Fakultas Pertanian Universitas Tadulako 93

16. Ucapan Terima Kasih 97

$\begin{array}{lr}\text { 17. Referensi } & 103\end{array}$ 



\section{1}

\section{Introduction}

$\mathrm{I}$

mproving agricultural management in tropical landscapes to contribute to both human well-being and the conservation of natural resources and biodiversity in rural livelihoods is a challenge (Millennium Ecosystem Assessment 2005; Foley et al., 2011; Tscharntke et al., 2012), but provides promising opportunities to support food security and ecosystem resilience. The productivity of agricultural landscapes in the tropics relies on services provided by the agroecosystem within which they occur, including the suppression of pests and diseases by natural enemies. Birds and bats are considered the two most effective predator groups of arthropods in tropical agricultural systems (e.g. Kalka et al., 2008; William-Guillén et al., 2008; Morrison \& Lindell 2012), connecting habitats in space and time due to their high mobility and functional diversity.

Comprehensive understanding of the relationships between biodiversity patterns, ecosystem services, agricultural landscape management, smallholder economics, and food security is lacking for smallholder farming systems in the tropics. Biodiversity-friendly management of tropical

\section{Pendahuluan}

$\mathrm{M}$ untuk kesejahteraan manusia dan konservasi sumber daya alam dan keragaman hayati di pedesaan merupakan sebuah tantangan (Millennium Ecosystem Assessment 2005; Foley $d k k$., 2011;. Tscharntke $d k k$., 2012), sekaligus peluang menjanjikan untuk dapat mendukung ketahanan pangan dan resiliensi ekosistem. Produktivitas kawasan bentang alam (lanskap) pertanian di daerah tropis bergantung pada jasa yang disediakan oleh agro-ekosistem di dalamnya, termasuk pembasmian hama dan penyakit tanaman oleh musuh alaminya. Burung dan kelelawar merupakan dua predator yang dianggap paling efektif terhadap artropoda di sistem pertanian tropis (e.g. Kalka dkk., 2008; WilliamGuillén dkk., 2008; Morrison \& Lindell 2012).

Pemahaman komprehensif tentang hubungan antara pola keragaman hayati, jasa ekosistem, manajemen lanskap pertanian, perekonomian petani kecil, dan ketahanan pangan masih belum dimiliki sistem pertanian kecil di daerah tropis. Manajemen keragaman hayati yang bijak pada 


\section{Central Sulawesi is not only}

the biggest producer of cacao

(Theobroma cacao L.) in the

third largest cacao producer

country Indonesia, but is also

the largest island within the

Indonesian biodiversity hotspot

Wallacea, characterized by an

outstanding high proportion of

endemic species from various

taxa. agricultural landscapes is a profitable alternative to the use of pesticides or other agrochemicals and represents a major pathway out of problematic land use strategies in Asia, which affect both biodiversity and local communities in negatif ways due to lacking sustainability and intensive resource utilization. Recommendations on wildlifefriendly farming practices require evidence based knowledge that has been tested under local conditions (e.g. Bommarco et al., 2013).

These knowledge gaps were addressed in the doctoral research project of Dr. Bea Maas, as part of the research activities from the Agroecology Group of the University of Göttingen (Germany). In collaboration with researcher of Tadulako University in Palu (Sulawesi, Indonesia), she and team investigated the ecological importance and the economic impact of ecosystem services provided by birds and bats in smallholder cacao plantations in Central Sulawesi (Indonesia).

Central Sulawesi is not only the biggest producer of cacao (Theobroma cacao L.) in the third largest cacao producer country Indonesia, but is also the largest island within the Indonesian biodiversity hotspot Wallacea, characterized by an outstanding high proportion of endemic species from various taxa.

Cacao is the dominant cash crop in this area, it became a major part of the agricultural landscapes only during a cacao boom development (Clough et al., 2009) around the 1980's, which has taken place largely in a context of 'handsoff policy' on behalf of government agencies (Akiyama \& Nishio 1996). The majority of the 


\section{Sulawesi Tengah bukan saja}

\section{penghasil kakao terbesar}

(Theobroma cacao L.) di

negara Indonesia- produsen

kakao terbesar ketiga di dunia,

tetapi juga merupakan pulau

terbesar di wilayah hotspot

keanekaragaman hayati

Wallacea, yang ditandai oleh

luar biasa tingginya proporsi

spesies endemik dari berbagi

taksa. lanskap pertanian tropis merupakan alternatif yang menguntungkan untuk penggunaan pestisida atau bahan kimia lainnya. Hal tersebut juga merepresentasikan jalan keluar yang baik dari penggunaan lahan yang bermasalah di Asia yang memberi pengaruh negatif untuk keragaman hayati dan masyarakat karena kurangnya keberlanjutkan (sustainability) dan penggunaan sumber daya yang intensif. Rekomendasi praktek pertanian yang ramah alam mensyaratkan pengetahuan berbasis bukti yang telah diuji pada kondisi lokal (e.g. Bommarco dkk., 2013).

Kesenjangan pengetahuan tersebut menjadi perhatian khusus dalam penelitian doctoral Dr. Bea Maas sebagai bagian dari kegiatan penelitian Bidang Agroekologi University of Göttingen (Jerman). Bekerja sama dengan peneliti Universitas Tadulako di Palu, Sulawesi Tengah (Indonesia), Dr. Maas dan tim meneliti arti penting ekologis dan dampak ekonomi dari jasa ekosistem yang diberikan oleh burung dan kelelawar pada petani kecil di perkebunan kakao di Sulawesi Tengah (Indonesia).

Sulawesi Tengah bukan saja memproduksi kakao (Theobroma cacao L.) terbanyak di Indonesia, negara ini rangking 3 produsen kakao dunia, juga merupakan pulau terbesar di area keragaman hayati Wallacea yang dicirikan oleh luar biasa tingginya proporsi spesies endemik dari berbagai taksa.

Kakao baru menjadi tanaman dominan di daerah ini sejak pengembangan besar-besaran kakao yang terjadi di tahun 1980an (Clough $d k k$., 2009) yang utamanya terjadi dalam konteks kebijakan lepas tangan (hands-off policy) pemerintah (Akiyama \& Nishio 1996). Mayoritas komunitas petani kecil bergantung pada fasilitas infrastruktur 
local smallholder community depends on simple infrastructure facilities and is traditionally not experienced in cacao cultivation, which complicates the cultivation of this introduced cash crop. Agroforestry management that integrates ecosystem services and diversified production for greater social, economic and environmental benefits (Schroth 2004; Jose 2009) is not yet recognized as profitable and sustainable land use strategy in this area.

The results of Dr. Maas' study contribute to improved biodiversity-friendly management in tropical cacao agroforestry landscapes in Central Sulawesi (Indonesia). The experimental design of the study has been used in a number of research projects in other tropical agroforestry systems, such as in African Macadamia farms, Brazilian coffee systems and oil palm plantations across the tropics.

In the cacao agroforestry landscape in Central Sulawesi, a comprehensive field study, conducted in cooperation with the local community of cacao smallholders, residents and students. It was conducted for investigating the agricultural landscape with respect to the importance and interrelations of ecosystem services, local plantation management, and landscape structure and smallholder economics.

Dr. Bea Maas and team continuously presented her research results to local farmers in Central Sulawesi, research institutes and universities in Indonesia (e.g., IPB and LIPI in Bogor). She also extensively discussed the importance of bird and bats ecosystem services with local communities and scientists. This book guide is created in collaboration with the University Tadulako and representatives from the local sederhana dan secara tradisional tidak berpengalaman dalam bercocok tanam kakao sehingga menambah kerumitan pembudidayaan tanaman yang baru diperkenalkan ini.

Manajemen agroforestri yang menggabungkan jasa ekosistem dan diversifikasi produksi untuk memberi manfaat sosial, ekonomi, dan lingkungan yang lebih besar belum dikenali sebagai strategi penggunaan lahan yang menguntungkan dan berkelanjutkan di daerah ini (Schroth 2004; Jose 2009).

Hasil penelitian Dr. Maas berkontribusi pada perbaikan manajemen yang ramah untuk keragaman hayati di lanskap agroforestri kakao tropis di Sulawesi Tengah. Desain eksperimental penelitian tersebut juga digunakan dalam sejumlah penelitian di wilayah agroforestri tropis lainnya, seperti di perkebunan Macadamia di Afrika, dan perkebunan kopi Brazil dan sawit di Negara tropis.

Studi lapangan komprehensif ini dilakukan di lanskap agroforestri kakao di Sulawesi Tengah, bekerja sama dengan komunitas petani kecil lokal, masyarakat setempat, dan mahasiswa. Penelitian ini dilakukan untuk menginvestigasi lanskap pertanian dengan fokus pada arti penting dan keterkaitan antara jasa ekosistem, manajemen perkebunan lokal, struktur lanskap dan juga perekonomian petani kecil.

Dr. Maas dan tim secara kontinu mempresentasikan hasil penelitiannya kepada petani di Sulawesi Tengah, universitas dan lembaga penelitian di Indonesia (seperti di IPB dan LIPI di Bogor). Ia juga berdiskusi secara ekstensif mengenai arti penting jasa ekosistem yang diberikan burung dan kelelawar dengan komunitas dan peneiliti lokal. Buku panduan ini dibuat bersama Universitas 
farming community in Central Sulawesi and does not only provide an insight into the results of this scientific project, it also provides practical advice for the use of ecosystem services of birds and bats in cacao agroforestry systems.

\section{Cacao Agroforestry Systems - Perspectives From Local Communities And Researchers}

The collaboration with the rural farmer community in Central Sulawesi has been developing since 2008, during the field work of Dr. Maas' diploma thesis, and has been continued until 2014. During the time of her doctoral studies, her scientific team comprised 46 local assistants and students, including cacao farmers which were involved in the scientific work during the whole research project and attended monthly meetings and discussion events. Tadulako University as host has facilitated the research and organized related permits.

The participation of all local assistants provides a strong benefit to the research activities in Central Sulawesi, since the research was designed with respect to applied questions and results and was tested under local conditions. In this guide, we mainly refer to two publications that resulted from our research activities in Central Sulawesi:

1.) Original Title: "Bats and birds increase crop yield in tropical agroforestry landscapes"

Article published 2013 in Ecology Letters; Authors: Maas, B., Clough, Y. and Tscharntke, T.
Tadulako dan perwakilan kelompok-kelompok tani di Sulawesi Tengah. Panduan ini tidak hanya berisi hasil-hasil penelitian tetapi juga panduan praktis untuk memanfaatkan jasa ekosistem yang diberikan oleh burung dan kelelawar dalam sistem agroforestri kakao.

\section{Sistem Agroforestri Kakao - Perspektif Dari Komunitas Lokal Dan Peneliti}

Kerja sama dengan komunitas petani lokal di Sulawesi Tengah telah dikembangkan sejak 2008 selama studi lapangan untuk thesis diploma Dr. Maas dan berlanjut hingga tahun 2014. Selama studi doktoralnya, tim peneliti Dr. Maas meliputi 46 orang asisten dan mahasiswa lokal, termasuk petani kakao. Mereka terlibat dalam tugas penelitian sepanjang masa studi dan juga menghadiri rapat serta diskusi bulanan. Universitas Tadulako sebagai tuan rumah memfasilitasi pelaksanaan penelitian serta membantu dalam mengurus perijinan.

Partisipasi asisten peneliti lokal memberikan keuntungan besar untuk aktivitas penelitian di Sulawesi Tengah, karena penelitian ini didesain dengan memperhatikan pertanyaan dan hasil yang diterapkan dan diuji pada kondisi lokal. Dalam panduan ini, kami terutama merujuk pada dua publikasi yang dihasilkan dari aktivitas penelitian yang telah dilakukan di Sulawesi Tengah sebelumnya.

1.) Judul aslinya: "Kelelawar Dan Burung Meningkatkan Hasil Produksi Tanaman Pada Lanskap Agroforestri Tropis" (Bats And Birds Increase Crop Yield In Tropical Agroforestry Landscapes). 
For the first time, the impact of arthropod suppression provided by birds and bats has been investigated in relation to local plantation management, landscape structure, multitrophic interaction and crop yield productivity in a large-scale, two-year exclosure experiment and was finally translated into economic values. Bird and bat exclusion increased insect herbivore abundance, caused mesopredator release of ants and spiders and negatively affected quality and quantity of the whole cacao fruit development across local (shade cover) and landscape (forest proximity) gradients. Consequently, the absence of bird and bat predation resulted in a tremendous economic impact on cacao crop yield (yield losses of $31 \%$, corresponding to USD 730 per ha and year), demonstrating the great potential of this service to contribute to poverty alleviation, local food security and hunger mitigation.

2.) "Avian Species Identity Drives Predation Success In Tropical Cacao Agroforestry." Article published 2015 in the Journal of Applied Ecology; Authors: Maas, B., Tscharntke, T., Shahabuddin, S., Dwi Putra, D. and Clough, Y.
Dipublikasikan pada tahun 2013 di Ecology

Letters; Penulis: Maas, B., Clough, Y. dan

Tscharntke, $T$.

Untuk pertama kalinya, dampak penekanan artropoda oleh burung dan kelelawar dikaji dalam kaitannya dengan dengan manajemen perkebunan lokal, struktur lanskap, interaksi multitropik dan produktvitas tanaman dalam eksperimen exclosure skala besar sepanjang dua tahun dan kemudian diterjemahkan dalam nilai ekonomi. Ketidakhadiran kelelawar dan burung meningkatkan melimpahnya serangga herbivore, menyebabkan lolosnya mesopredator seperti semut dan laba-laba, dan menimbulkan dampak negatif untuk kualitas dan kuantitas pengembangan buah kakao secara menyeluruh pada gradien area loka (pohon naungan) dan lanskap (jarak dengan hutan). Sebagai konsekuensinya, ketidakhadiran kelelawar dan burung menghasilkan pengaruh ekonomi yang sangat besar terhadap produksi tanaman kakao (penurunan hasil sebesar 31\%, setara dengan USD 730 per hektar per tahun). Ini menunjukkan potensi besar jasa ekosistem yang diberikan oleh burung dan kelelawar pada pengurangan kemiskinan, ketahanan pangan lokal, dan pencegahan kelaparan.

2.) "Identitas Spesies Burung Yang Mendorong Kesuksesan Predasi Pada Agroforestri Kakao Tropis."

Dipublikasikan pada tahun 2015 di Journal of Applied Ecology; Penulis: Maas, B., Tscharntke, T., Shahabuddin, S., Dwi Putra, D. dan Clough, Y. 
The research identified those bird species that drive pest insect predation in cacao agroforestry landscapes by using a combination of field predation experiments and two species sampling methods, targeting on different parts of the insectivorous bird community. This study provides applied management recommendations for cacao farmers in Central Sulawesi who desire a targeted management of avian ecosystem services. This could be achieved by taking into account species-specific functions and forest proximity to enhance the densities of the Lemon-bellied White-eye (Zosterops chloris), rather than species diversity.

In addition, we will refer to knowledge and publications on sustainable use of cacao agroforestry that have been studied by Dr. Yann Clough, Dr. Arno Wielgoss and other scientists from the Agroecology group of the University of Göttingen, in collaboration with many other scientists from Germany and Indonesia.

In conclusion, this guide provides first insights and recommendations on the high value and economic impact of biodiversity and ecosystem services in tropical agricultural landscapes. We report discussions from an awareness training programme that has been conducted after the research activities in 2014 and aimed to communicate the benefits of integrating ecosystem service in agroforestry management, thereby increasing the perception and valuation of biodiversity by rural community and farmers.
Penelitian ini mengidentifikasi spesies-spesies burung yang mendorong predasi serangga hama di lanskap agroforestri kakao dengan menggunakan kombinasi eksperimen lapangan dan dua metode species sampling yang menyasar bagian yang berbeda dari kelompok burung insektivora. Penelitian ini menghasilkan rekomendasi manajemen untuk petani kakao di Sulawesi Tengah yang menginginkan manajemen yang terfokus atas jasa ekosistem burung. Hal ini bisa dicapai dengan lebih memperhitungkan fungsi khas spesies tertentu dan kedekatan hutan untuk meningkatkan kepadatan Kacamata Laut (Zosterops chloris) daripada keragaman spesies.

Selain itu, kami juga merujuk pada pengetahuan dan publikasi mengenai pemanfaatan agroforestri kakao secara berkelanjutan yang telah diteliti oleh Dr. Yann Clough, Dr. Arno Wielgoss, dan peneliti-peneliti lain dari kelompok peneliti Agroekologi Universitas Göttingen Jerman yang berkolaborasi dengan banyak peneliti lainnya dari Jerman dan Indonesia.

Kesimpulannya, panduan ini memberikan gambaran awal dan rekomendasi mengenai nilai penting dan dampak eknomi keragaman hayati dan jasa ekosistem di lanskap pertanian tropis. Kami melaporkan pembahasan dari program penyuluhan yang telah dilaksanakan setelah aktivitas penelitian pada tahun 2014 yang bertujuan untuk mengkomunikasikan manfaat integrasi manajemen jasa ekosistem dalam manajemen agroforestri yang kemudian meningkatkan persepsi dan nilai keragaman hayati di mata masyarakat desa dan petani. 



\section{2}

\section{About the \\ Research Project}

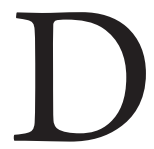

r. Bea Maas conducted the research project as part of her Ph.D thesis that was designed as a follow-up study of her former master thesis in Central Sulawesi. The research started in January 2010 and was conducted until August 2011. For her study, Bea Maas installed so-called "exclosure experiments" on 15 different cacao smallholder plantations in Central Sulawesi. These experiments were conducted to manipulate the access of birds and bats to 120 cacao trees to investigate the effect of natural insect and spider predation on cacao crop yield and cacao fruit development.

Natural pest control by birds and bats is regarded as one of the most important "ecosystem services" in tropical countries. Because of the high functional diversity of birds and bats (high variety of feeding guilds and habitats in which they occur) as well as their high mobility, they experience many different resources in different landscape types. Depending on the availability of resources and the structure of the landscape, birds and bats are able to reduce the amount of different insects

\section{Tentang Kegiatan Penelitian Ini}

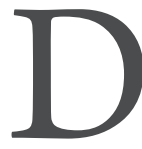
r. Bea Maas melakukan penelitian ini sebagai bagian dari penelitian S3 yang merupakan kelanjutan dari penelitian S2-nya di Sulawesi Tengah. Penelitian tersebut dilakukan pada Januari 2010 hingga Agustus 2011. Untuk kebutuhan penelitiannya, Dr. Bea Maas menggunakan metode "eksperimen eksklusi” (mengeluarkan spesies tertentu dari suatu kawasan) di 15 kebun kakao rakyat yang berbeda di Sulawesi Tengah. Eksperimen tersebut dilakukan untuk memanipulasi akses burung dan kelelawar pada 120 pohon kakao untuk menginvestigasi pengaruh predasi serangga dan laba-laba pada produksi dan perkembangan buah kakao.

Pengendalian hama secara alami oleh burung dan kelelawar dianggap sebagai satu "jasa ekosistem” penting di negara-negara tropis. Berkat keragaman fungsional burung dan kelelawar yang tinggi (tingginya variasi feeding guilds dan kawasan habitat) dan juga tingginya mobilitas mereka, burung dan kelelawar merasakan berbagai sumber daya yang berbeda di lanskap yang berbeda. Bergantung pada ketersediaan sumber daya dan struktur lanskap, burung dan kelelawar 


\section{Ecosystem services ( $\mathbf{s}$ ) Jasa ekosistem (j)}

Provisioning

$\mathrm{s} . / \mathrm{j}$

penyediaan

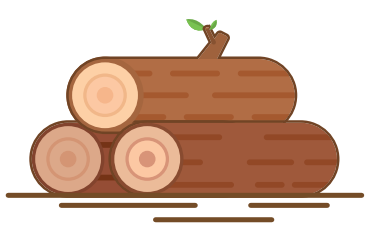

Supporting

s./j

pendukung

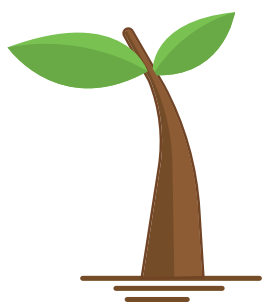

Fig. 1

Humankind benefits in a multitude of ways from ecosystems. Collectively, these benefits are becoming known as ecosystem services. Image credits: B. Maas

(including many pest insects) and thereby contribute to the ecosystem service of "natural pest control" which can be highly beneficial for humans, especially owners of land use systems such as cacao and coffee. The suppression of insects and spiders can lead to a reduction of crop pests and therefore result in increased crop yield.

Cacao plantations have become a major land use system in Central Sulawesi which is today the largest producer of cacao in Indonesia, the third largest cacao producer worldwide (Moser et al., 2010).

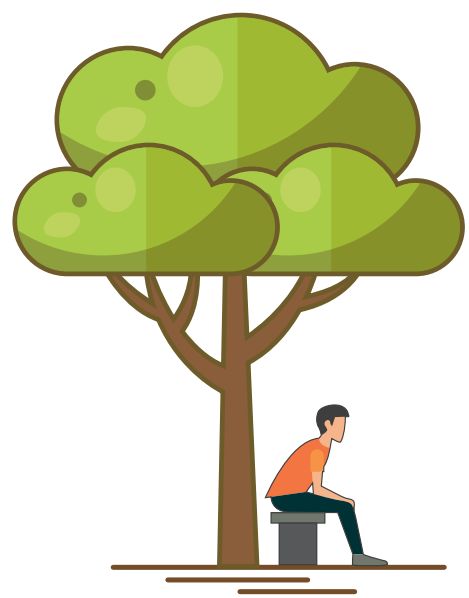

Grr. 1

Manusia memperoleh beragam manfaat dari ekosistem. Secara kolektif, manfaat-manfaat tersebut dikenal sebagai jasa ekosistem. Gambar: B. Maas

dapat mereduksi jumlah beragam serangga (termasuk serangga hama) dan dengan demikian berkontribusi pada jasa ekosistem "pengendalian hama alami” yang bisa sangat menguntungkan untuk manusia, khususnya pemilik lahan kakao dan kopi. Penekanan jumlah serangga dan labalaba dapat mengurangi serangga hama sehingga mampu meningkatkan hasil produksi tanaman.

\section{Perkebunan kakao (Theobroma Cacao)} merupakan pengguna lahan utama di Sulawesi Tengah yang saat ini merupakan penghasil kakao terbesar di Indonesia dan ketiga terbesar di dunia (Moser dkk., 2010). 
This agroforestry system (agroforestry: the practice of integrating crops with trees and other large woody long-lived woody plants) can be managed very differently, since the amount of local shade (often provided by "Gamal" and "Dadap" trees; Scientific names: Gliricidia sp. and Erythrina sp.) can vary between plantations. In addition, the application of agrochemicals (e.g. pesticides; herbicides; fungicides) and the amount of different land use components within the plantations (e.g. "polyculture systems") greatly differ between plantations. Depending on the local and the landscape management, cacao plantations can support high biodiversity levels and therefore profit from ecosystem services provided by different species (e.g. birds, bats, ants).

Our research project focused on the predation services provided by birds and bats. On 15 differently managed cacao plantations in Central Sulawesi (Napu valley; eastern border of the Lore Lindu National Park), we conducted field experiments for 18 months continuously. The results presented in this report include our findings on the effects of bird and bat predation services on:

(a) fruit development and crop yield of cacao

(b) insect and spider densities in cacao, including different pest insects

(c) leaf damage

(d) incidence of crop diseases (e.g. Cacao Pod Borer, Black Pod Disease)
Sistem agroforestri ini (agroforestri: praktik perkebunan yang mengintegrasikan tanaman perkebunan dengan pohon-pohon dan tumbuhan besar berkayu berumur panjang lainnya) dapat dikelola dengan cara sangat berbeda, mengingat jumlah beberapa pohon naungan — seringkali berupa pohon "Gamal” (Gliricidia sp.) dan "Dadap" (Erythrina sp.) - dapat berbeda di tiap perkebunan. Penggunaan bahan kimia (seperti pestisida, herbisida, fungisida) dan jumlah komponen penggunaan lahan yang berbeda dalam perkebunan (misalnya sistem polikultur) juga sangat bervariasi di antara perkebunanperkebunan yang ada. Bergantung pada masyarakat dan manajemen lanskap, perkebunan kakao dapat mendukung keragaman hayati yang tinggi dan memperoleh keuntungan jasa ekosistem yang diberikan oleh spesies berbeda (seperti burung, kelelawar, semut).

Proyek penelitian kami berfokus pada jasa predasi yang dilakukan oleh burung dan kelelawar. Kami melakukan eksperimen lapangan selama 18 bulan berturut-turut di lima belas perkebunan kakao dengan manajemen yang berbeda di Sulawesi Tengah (Lembah Napu; perbatasan timur dari Taman Nasional Lore Lindu). Hasil yang disajikan dalam laporan ini mencakup temuan kami pada dampak jasa predasi burung dan kelelawar pada:

a. perkembangan buah dan hasil produksi kakao

b. kepadatan populasi serangga dan laba-laba di perkebunan kakao, termasuk serangga hama yang berbeda

c. kerusakan daun

d. kejadian penyakit tanaman (misalnya penggerek buah, penyakit busuk buah) 
Birds and bats are able to reduce the amount of different insects (including many pest insects) and thereby contribute to the ecosystem service of "natural pest control" which can be highly beneficial for humans, especially owners of land use systems such as cacao and coffee.
Ecosystem services are regularly involved in the provisioning of clean drinking water and the decomposition of wastes. While scientists and environmentalists have discussed ecosystem services implicitly for decades, the ecosystem services concept itself was popularized by the Millennium Ecosystem Assessment (MA) in the early 2000s. This grouped ecosystem services into four broad categories: provisioning, such as the production of food and water; regulating, such as the control of climate and disease; supporting, such as nutrient cycles and crop pollination; and cultural, such as spiritual and recreational benefits. To help inform decisionmakers, many ecosystem services are being assigned economic values. 
Burung dan kelelawar dapat

mereduksi jumlah beragam

serangga (termasuk serangga

hama) dan dengan demikian

berkontribusi pada jasa

ekosistem "pengendalian

hama alami" yang bisa sangat

menguntungkan untuk manusia,

khususnya pemilik lahan kakao

dan kopi.
Jasa ekosistem terlibat secara teratur dalam penyediaan air minum bersih dan dekomposisi limbah. Sementara para ilmuwan dan pemerhati lingkungan telah membahas jasa ekosistem secara implisit selama puluhan tahun, konsep "jasa ekosistem" sendiri dipopulerkan oleh Millennium Ecosystem Assessment (MA) di awal tahun 2000an. Jasa ekosistem dikelompokkam ke dalam empat kategori besar: penyediaan, seperti produksi makanan dan air; pengaturan, seperti pengendalian iklim dan penyakit menular; pendukung, seperti siklus hara dan penyerbukan tanaman; dan budaya, seperti manfaat spiritual dan rekreasional. Untuk membantu memberi informasi pada para pembuat keputusan, banyak jasa ekosistem diberi nilai ekonomi. 



\section{3 \\ Study Area and \\ Selected Study Sites}

\section{3 \\ Lokasi dan Petak Penelitian yang Terseleksi}

ll sites were situated at the northern
tip of Napu Valley in Central Sulawesi,
Indonesia ( $1^{\circ} 25^{\prime} 32^{\prime}$ S, $120^{\circ} 18^{\prime} 54^{\prime}$ E) at the eastern border of the Lore Lindu National Park (Fig. 2).

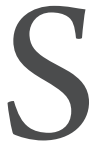
eluruh lokasi penelitian terletak di ujung utara Lembah Napu di Sulawesi Tengah, Indonesia ( $1^{\circ} 25^{\prime} 32$ “S, $120^{\circ} 18^{\prime} 54^{\prime}$ E) di perbatasan timur Taman Nasional Lore Lindu (Gbr. 2).
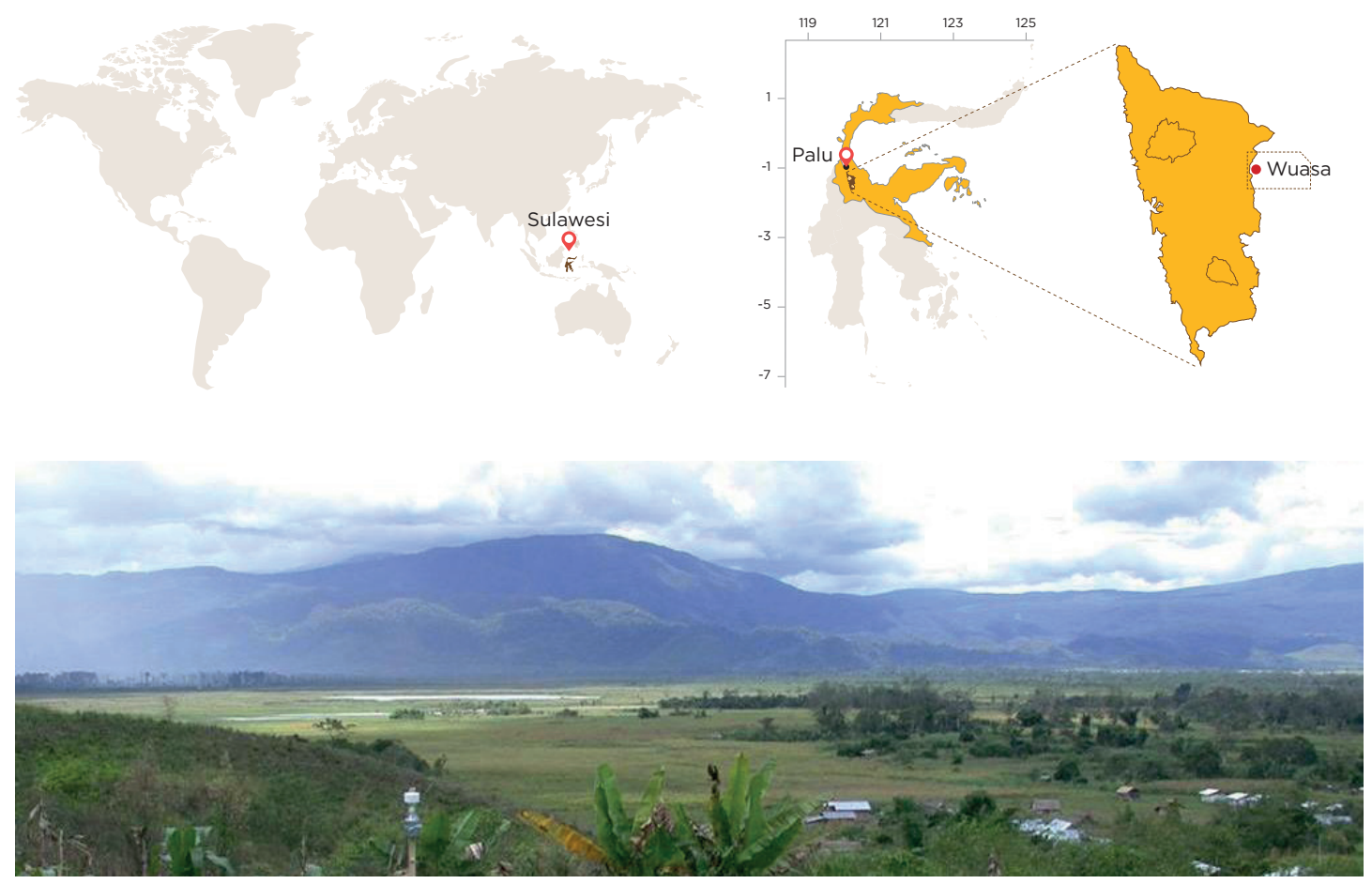

Fig. 2: The research was conducted in Central Sulawesi (top right), in the Napu Valley (picture at the bottom), at the eastern border of the Lore-Lindu National Park. Photo credits: B.Maas
Gbr. 2: Penelitian dilaksanakan di Sulawesi Tengah (kanan atas), di Lembah Napu (gambar bawah), perbatasan sisi timur Taman Nasional Lore-Lindu. Foto: B.Maas 


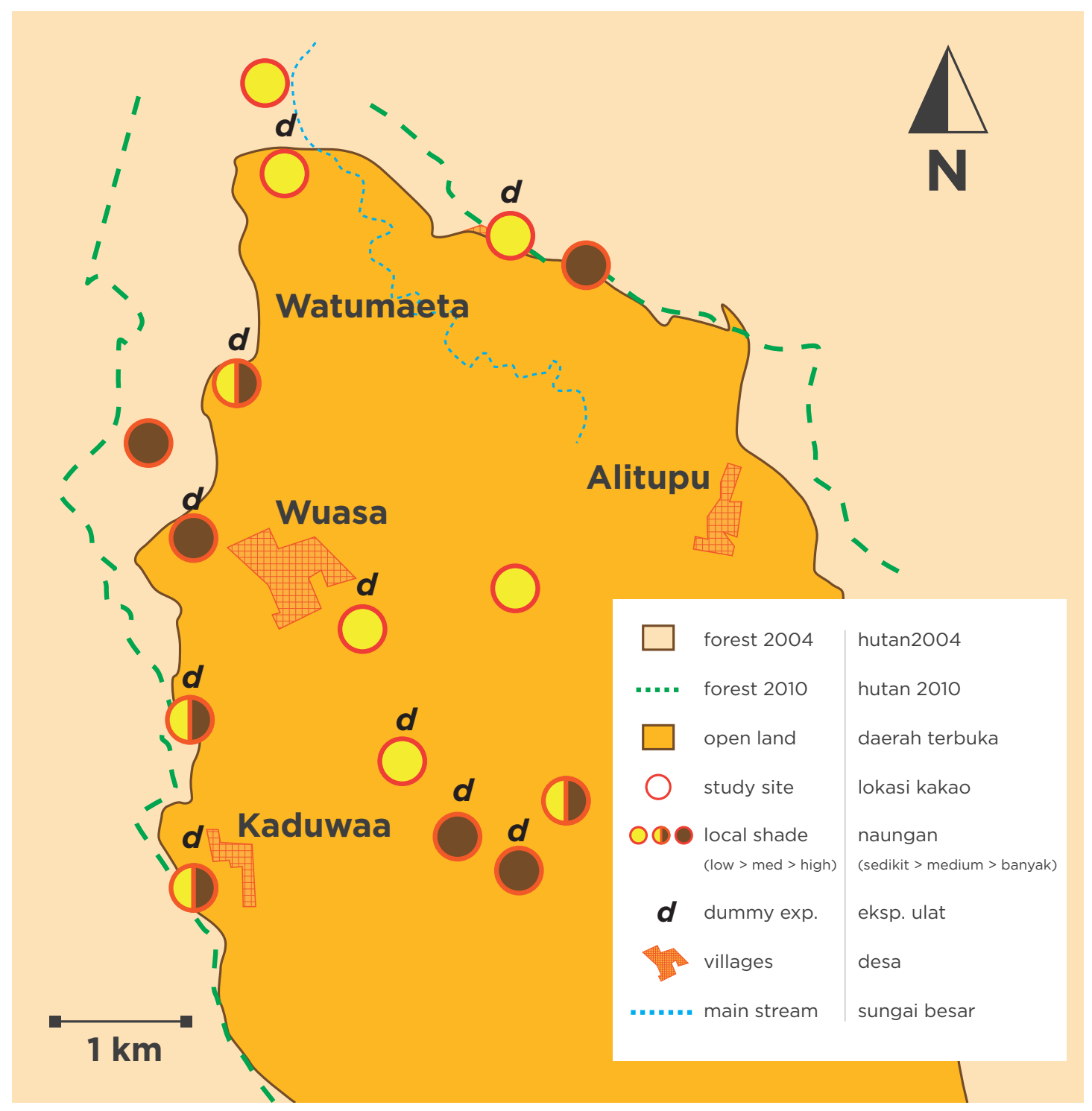


After an initial mapping of the study area, we selected 15 smallholder cacao plantations as sites for our exclosure experiments in March 2010. All cacao sites were distributed along two different gradients:

a. a local gradient of shade tree availability at the site $(0-75 \%)$, and

b. a landscape gradient of different distances to the primary forest $(0-3000 \mathrm{~m})$. An overview of our sites is provided in Fig. 3 .
Setelah pemetaan awal daerah penelitian, kami memilih 15 perkebunan kakao rakyat sebagai lokasi untuk eksperimen exclosure kami di bulan Maret 2010. Semua kebun kakao tersebut terbagi dalam dua gradien yang berbeda:

a. gradien lokal dalam hal ketersediaan pohon naungan (0-75\%), dan

b. gradien lanskap dari beragam jarak ke hutan primer $(0-3000 \mathrm{~m})$. Gambaran umum lokasi penelitian dapat dilihat pada Gbr. 3 .

Fig. 3: Schematic map of the location of cocoa research. Light brown color indicates the area of primary forest, partly belonging to the Lore Lindu National Park in 2004 (at the western side). The dashed line represents the forest margin line at the time of our study (2010). Yellow color indicates human-dominated open land in the Napu Valley (dominated by different agriculture systems and settlements). For our study, we selected 15 cocoa plantations alongdifferent distances to primary forest (0 to $3000 \mathrm{~m}$ ) and with different amount of local shade cover: 0-25\% (empty circles); 25-50\% (halffilled circles) and more than 50\% (filled brown circles). The letter " $d$ " indicates the 10 locations selected for "caterpillar experiments" (dummy experiments with artificial caterpillars). Source: graph adapted from PhD thesis of B.Maas.

Gbr. 3: Peta skematik lokasi penelitian kakao. Warna cokelat muda menunjukkan daerah hutan primer, sebagian milik Taman Nasional Lore Lindu pada tahun 2004 (di sisi barat). Garis putus-putus mewakili garis batas hutan pada saat penelitian (2010). Warna kuning menunjukkan lahan terbuka yang didominasi oleh penduduk di Lembah $\mathrm{Napu}$ (didominasi oleh sistem pertamanan dan permukiman yang berbeda). Untuk penelitian, kami memilih 15 perkebunan kakao yang berdekatan dengan hutan primer (jarak 0 sampai $3000 \mathrm{~m}$ ) dan dengan jumlah tutupan naungan yang berbeda: 0-25\% (lingkaran kosong); 25-50\% (lingkaran setengah penuh) dan lebih dari 50\% (lingkaran cokelat penuh). Huruf "d" menunjukkan 10 lokasi yang dipilih untuk "percobaan ulat" (eksperimen menggunakan ulat buatan). Sumber : grafik diadaptasi dari tesis S3 B. Maas. 



\section{4}

\section{Main Experiment: Exclosure of Birds and Bats}

W th the experimental exclosure of birds and bats we create a scenario of reduced bird and bat density or presence on our study sites. This scenario is realistic, given the great loss of natural habitat and habitat diversity in many tropical areas (including Central Sulawesi), which is well known to cause significant decrease of species diversity (e.g. Maas et al., 2009).

Furthermore, land use intensification leads to decreased species diversity and therefore decreased amounts of ecosystem services (such as reduction of pest insects) which are provided by birds and bats (e.g. Lawton et al., 1998; Daily, 2001).

Our main experimental approach to study the effects of birds and bats on cacao was therefore to exclude them within a large-scale field experiment. For this experiment, we set up 4 exclosure cages in each of the 15 cacao plantations (see Fig. 4).

\section{4}

\section{Eksperimen Utama: Eksklusi Burung dan Kelelawar}

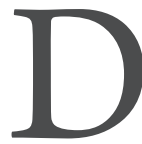
engan eksperimen eksklusi (tanpa) burung dan kelelawar (meniadakan burung dan kelelawar dari kawasan kebun kakao), kami membuat skenario berkurangnya kepadatan burung dan kelelawar di lokasi penelitian kami. Skenario ini adalah merefleksikan keadaan yang sebenarnya, mengingat besarnya penurunan habitat alami (seperti hutan primer) dan keragaman habitat di banyak daerah tropis (termasuk Sulawesi Tengah) yang diketahui menyebabkan penurunan yang signifikan dari keragaman spesies (Maas dkk., 2009).

Selain itu, intensifikasi lahan menyebabkan penurunan keragaman spesies dan kemudian penurunan jasa ekosistem (seperti pengurangan serangga hama) oleh burung dan kelelawar (contoh: Lawton dkk., 1998; Daily, 2001).

Pendekatan eksperimen kami dilakukan untuk mempelajari pengaruh burung dan kelelawar pada kakao. Oleh karena itu, yang dilakukan adalah meniadakan mereka dalam eksperimen lapangan skala besar. Untuk eksperimen ini, kami membangun empat area eksklusi yang disungkup dengan jaring di setiap perkebunan kakao pada 15 lokasi (Gbr. 4). 


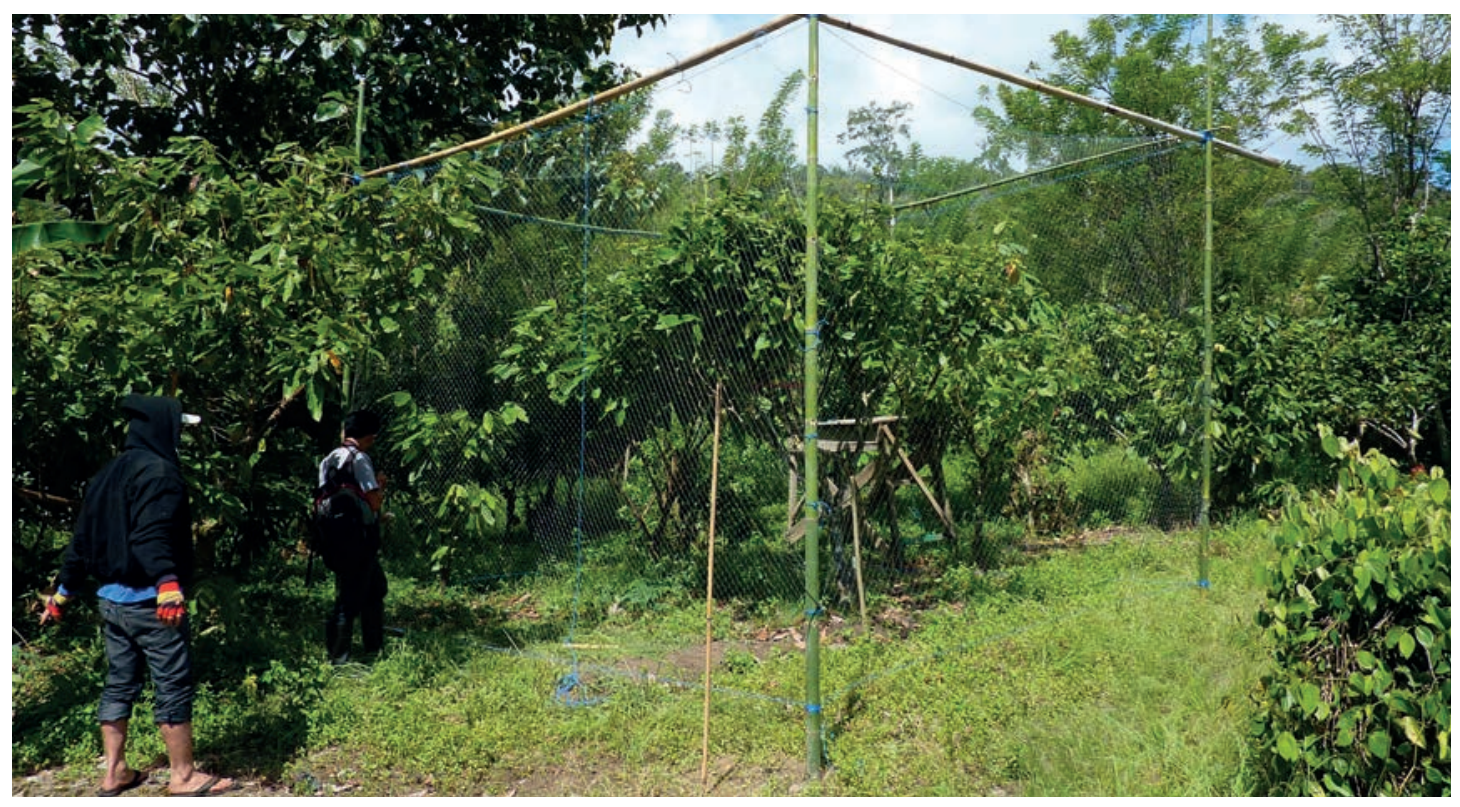

Fig. 4: Two examples of exclosure treatments in cacao plantations (in each plantation there was one treatment for a) bird exclosure; $b$ ) bat exclosure; c) full exclosure and d) control. In each treatment cage, there were two cacao trees (Theobroma cacao) within the exclosure construction of bamboo and fisher net made by nylon monofilament (mesh size: $2 \times 2 \mathrm{~cm}$ ). Photo credits: B. Maas.

Gbr. 4: Dua contoh perlakuan eksklusi di perkebunan kakao (di setiap perkebunan terdapat satu perlakuan untuk: a) meniadakan burung; b) meniadakan kelelawar; c) meniadakan burung dan kelelawar, dan d) kontrol. Di setiap sungkup yang diberi perlakuan terdapat dua pohon kakao (Theobroma cacao) dalam area yang disungkup dengan menggunakak rangka bambu dan jaring nilon monofilamen (ukuran lubang jaring: $2 \times 2 \mathrm{~cm}$ ). Foto: $B$.

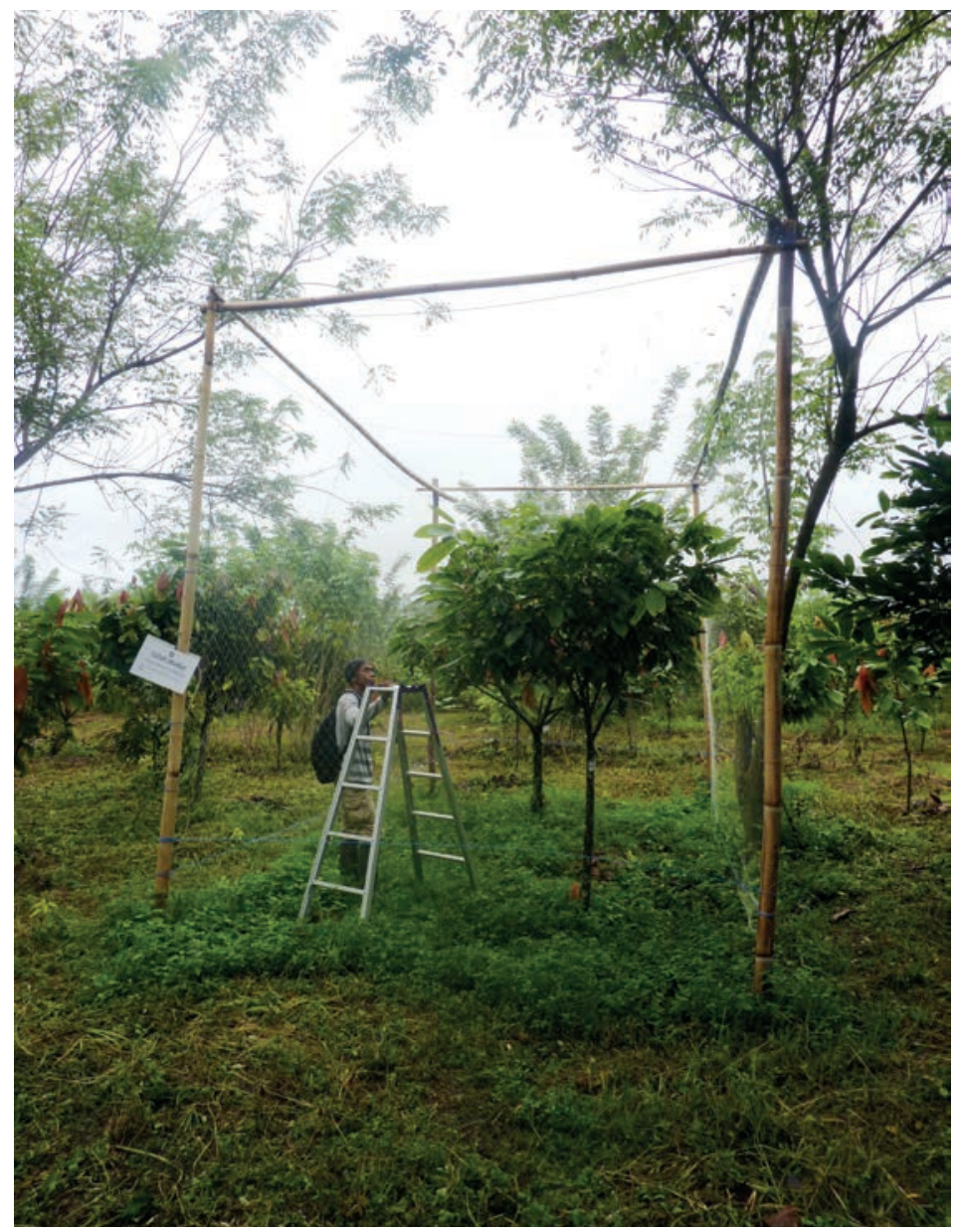
Maas. 
Each cage could be opened and closed daily. The four cages were used to:

1. exclude birds (cage closed during the day; open during the night)

2. exclude bats (cage closed during the night; open during the day)

3. exclude both birds and bats (cage always closed)

4. the natural conditions of the single cacao plantation with bird and bat access being not manipulated (open cage as a non-manipulated control).

Each cage was covered by a fisher net (mesh size $2 \times 2 \mathrm{~cm}$ ) that allowed all insects to enter and leave the cage, but that was preventing bird or bat access when it was closed (according to the activity times of birds and bats).

In total, our experimental field research covered 15 smallholder cacao plantations (study sites), 60 treatments for the exclosure experiments (exclosure cages) and 120 cacao study trees inside these treatments (two cacao trees per treatment).
Setiap sungkup bisa dibuka dan ditutup setiap hari. Keempat sungkup tersebut digunakan untuk:

1. meniadakan burung (sungkup ditutup pada siang hari dan dibuka pada malam hari),

2. meniadakan kelelawar (sungkup ditutup pada malam hari; terbuka selama siang hari),

3. meniadakan burung dan kelelawar (sungkup selalu tertutup)

4. menunjukkan kondisi alami pada satu perkebunan kakao di mana keberadaan burung dan kelelawar tidak dimanipulasi (sungkup terbuka sebagai kelompok kontrol yang tidak dimanipulasi).

Setiap sungkup ditutup dengan jaring (ukuran lubang $2 \times 2 \mathrm{~cm}$ ) yang memungkinkan semua serangga untuk masuk dan keluar, namun mencegah akses Burung atau kelelawar saat jaring dalam kondisi tertutup (sesuai dengan waktu aktivitas burung dan kelelawar).

Secara keseluruhan, penelitian lapangan kami mencakup 15 perkebunan kakao rakyat(lokasi penelitian), 60 perlakuan untuk eksperimen exclosure (area kebun yang disungkup dengan jaring) dan 120 pohon kakao (dua pohon kakao untuk setiap perlakuan). 



\section{5}

\section{Research Questions}

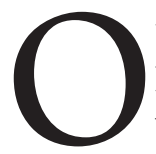

ur study represents one of the first large-scale exclosure experiments of birds and bats in tropical agroforestry systems. Furthermore, we provide first findings from Southeast Asia. Previous studies did not include a combination of local and landscape effects on crop yield productivity or did not take into account the multitrophic interactions that occur between top predators (birds and bats), mesopredators (ants and spiders) and herbivores (often regarded as pest insects).

The main research questions were:

(1) How do insectivorous birds and bats affect insects (including pests) and spiders in cacao agroforestry systems?

(2) Does the suppression of pest insects lead to an increase of cacao yield and can this effect be translated into economic values (USD/ ha/year)?

(3) How do local shade tree availability and landscape structure (distance to primary forest) affect predation services and crop yield productivity?

(4) Which species are important for the provision of effective predation services in cacao?
$\mathrm{P}$ enelitian kami mewakili salah satu eksperimen eksklusi berskala besar pertama terhadap burung dan kelelawar dalam sistem agroforestri tropis. Lebih jauh, kami menampilkan hasil penemuan pertama di Asia Tenggara. Penelitian-penelitian sebelumnya tidak memasukkan kombinasi pengaruh keadaan lokal dan lanskap pada produktivitas hasil panen atau tidak memperhitungkan interaksi multitropik antara pemangsa puncak (burung dan kelelawar), mesopredator (semut dan laba-laba) dan herbivora (sering disebut sebagai serangga hama).

Pertanyaan utama penelitian kami adalah:

(1) Bagaimana burung dan kelelawar pemakan serangga mempengaruhi populasi serangga (termasuk hama) dan laba-laba dalam sistem pertanian agroforestri kakao?

(2) Apakah penekanan jumlah serangga hama menyebabkan peningkatan hasil panen kakao dan berdampak pada peningkatan ekonomi (USD per hektar dan tahun)?

(3) Bagaimana ketersediaan pohon naungan local dan struktur lanskap (jarak dari hutan primer) mempengaruhi jasa predasi dan produktivitas hasil panen?

(4) Spesies mana yang penting bagi penyediaan jasa predasi yang efektif dalam sistem pertanian agroforestri kakao? 



\section{6}

\section{What Was}

Investigated During

Our Research?

\section{Apa Saja yang \\ Diselidiki Selama Penelitian Kami?}

$\mathrm{F}$ rom March 2010 until August 2011 we conducted our exclosure experiment of birds and bats on 15 different cacao plantations, which presented our study sites. Within that period, we collected data on all our 120 cacao study trees for 15 months continuously. Our field work and data collection included the following topics:

\section{Insects and spiders}

Method: These observations were conducted during daytime (07 AM - $01 \mathrm{PM}$ ) and the nighttime (08 PM - $02 \mathrm{AM})$. A time standard of 25 minutes per tree was used for every survey. We observed and identified all insects and spiders on the cacao study trees (starting from the bottom and controlling all parts of the cacao trees, including branches, flowers, fruits until and the cacao canopy). In addition to the surveys, a digital camera was used to document insects and spiders for identification after the survey. We recorded position, size and characteristics (e.g. color, anatomy) of each recorded individual.

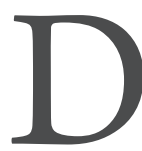
ari bulan Maret 2010 sampai Agustus 2011 kami melakukan eksperimen eksklusi di 15 perkebunan kakao yang berbeda. Dalam periode tersebut, kami mengumpulkan data dari 120 pohon kakao yang diteliti selama 15 bulan berturut-turut. Kerja lapangan dan pengumpulan data kami mencakup topik-topik berikut:

\section{Serangga dan laba-laba}

Metode: Pengamatan ini dilakukan pada siang hari (07:00 - 13:00) dan malam hari (20:00 - 02:00). Waktu standar selama 25 menit per pohon digunakan untuk setiap pengamatan. Kami mengamati dan mengidentifikasi semua serangga dan laba-laba di pohon-pohon kakao yang diteliti (mulai dari bawah dan mengamati semua bagian pohon kakao tersebut, termasuk cabang, bunga, buah sampai kanopi kakao). Selain survei, kamera digital juga digunakan untuk mendokumentasikan serangga dan laba-laba untuk keperluan identifikasi setelah survei. Kami mencatat posisi, ukuran dan karakteristik (misalnya warna, anatomi) dari setiap individu yang teramati. 
Survey period and data output: Every month, we conducted one day and one night survey on each of our 120 study trees ( 15 study sites). In total, we observed 47,406 night-active and dayactive insects and spiders belonging to 16 orders and 65 families, from which 32,537 individuals from eight target orders of insects and spiders (from at least 46 families) were included in our analyses (See Table 1 on page 36 ).

\section{Cacao fruit development and cacao diseases}

Method: During the period of our study, our team was taking care of the cacao harvest and investigated the fruit production to quantify the effects of bird and bat predation on cacao fruit development. We investigated the fruit development including counting of flowers, counting of fruits in all development stages, harvesting the fruits and finally drying the yield (separately for every exclosure treatment; see Fig. 5). During these investigations, we also recorded cacao diseases (e.g. Black Pod Disease; Cacao Pod Borer) and we separated cacao seeds of good quality and lower quality. This way, we could investigate the final yield outcome (marketable yield) for every treatment (60 treatments on 15 plantations), which included two cacao trees each. As soon as the investigation of cacao crop yield was finished, we gave the yield back to the plantation owners.
Periode survei dan data yang dihasilkan:

Setiap bulan, kami melakukan survei selama satu hari (siang hari) dan satu malam (survei malam hari) pada setiap pohon yang diteliti dengan jumlah 120 pohon kakao di 15 lokasi penelitian. Secara keseluruhan, kami mengamati 47.406 serangga dan laba-laba yang aktif di siang hari dan malam hari yang berasal dari 16 ordo dan 65 famili. Dari jumlah tersebut, 32.537 individu dari delapan ordo serangga dan laba-laba yang disasar (dari setidaknya 46 famili) dimasukkan dalam analisis kami (lihat Tabel 1 di halaman 36).

\section{Perkembangan buah kakao dan penyakit kakao}

Metode: Selama periode penelitian, kami menangani panen kakao dan menyelidiki produksi buah untuk mengukur pengaruh predasi burung dan kelelawar pada perkembangan buah kakao. Kami meneliti perkembangan buah termasuk menghitung bunga di semua tahap pertumbuhan, memanem buah, dan akhirnya mengeringkan hasil panen (dilakukan secara terpisah untuk setiap sungkup eksperimen; lihat Gbr. 5. )Selama penelitian ini, kami juga mencatat semua penyakit kakao (misalnya penyakit busuk buah, penggerek buah) dan memisahkan biji kakao berkualitas baik dan yang berkualitas lebih rendah. Dengan cara ini, kami dapat meneliti hasil akhir (hasil panen yang dapat dijual) untuk setiap perlakuan (60 perlakuan pada 15 kebun), yang terdiri dari dua pohon kakao di dalam setiap perlakuan. Segera setelah penelitian hasil panen kakao selesai, kami memberikan kembali hasil panen ke pemilikpemilik kebun kakao. 

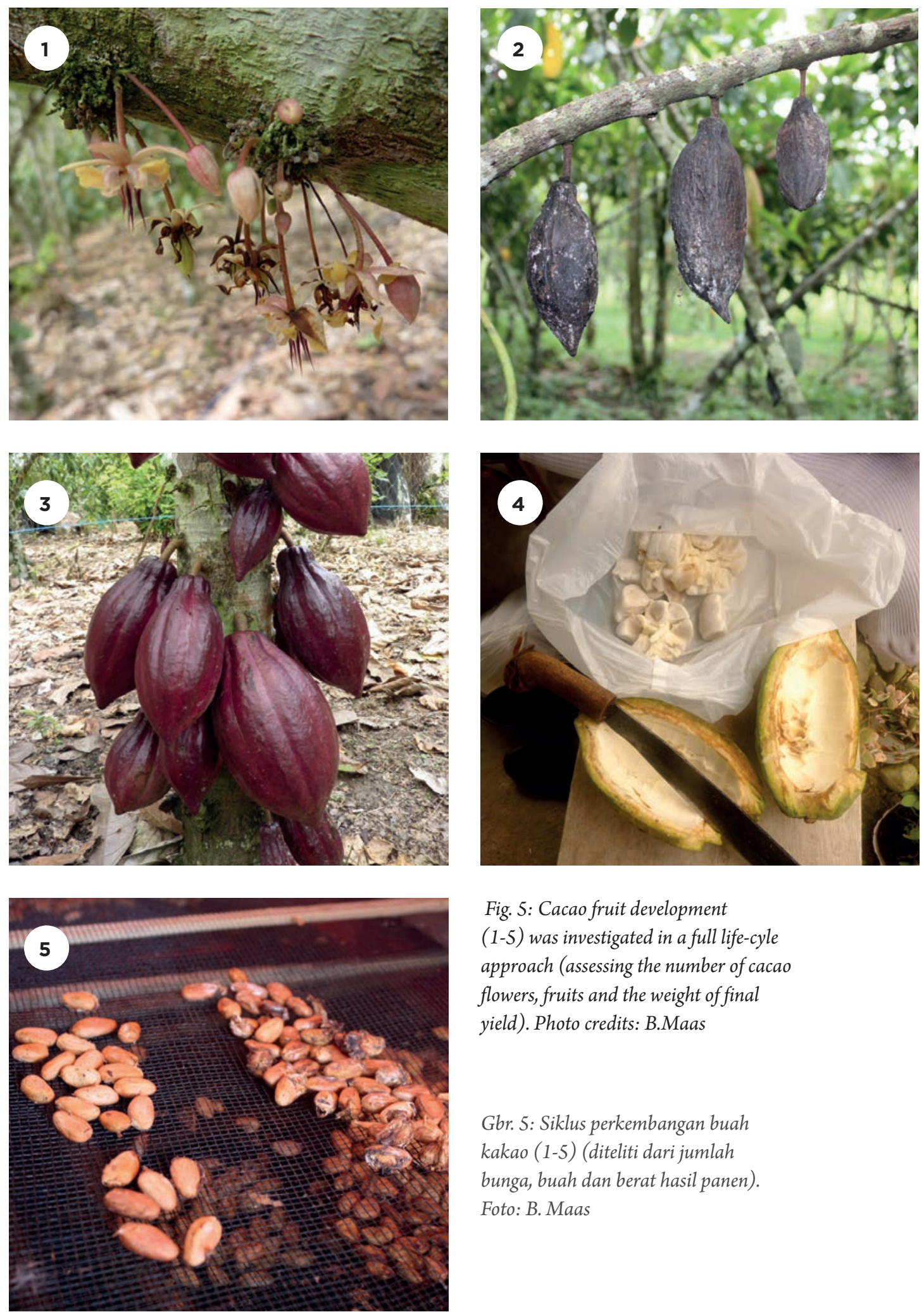

Fig. 5: Cacao fruit development

(1-5) was investigated in a full life-cyle approach (assessing the number of cacao flowers, fruits and the weight of final yield). Photo credits: B.Maas

Gbr. 5: Siklus perkembangan buah kakao (1-5) (diteliti dari jumlah bunga, buah dan berat hasil panen). Foto: B. Maas 
Survey period and data output: The dry cacao seeds $(\mathrm{kg} /$ subplot) represent cacao yield in our analyses. In total, we surveyed 75,576 fruits from which 4,071 were harvested in 28 survey rounds.

\section{Bird community and bird predation success}

Method: In September 2010 and from February until June 2011 (total of 7 months and visits per site), we conducted monthly "point count" and "mist netting sampling" of birds on each of the 15 study sites. Points counts were based on 20 minutes surveys conducted in ten center of each cacao plantation (survey size of 50x50 m), in which birds were identified visually or acoustically (bird voice). Mist netting sampling is based on a standardized scientific method with which birds are captured with songbird-nets ( $48 \mathrm{~m}$ length in total using 8 songbird mist nets of $6 \times 3 \mathrm{~m}$ size and $16 \mathrm{~mm}$ mesh size). Both sampling methods were always conducted on the same date in each plantation (Fig. 6).
Periode survei dan data yang dihasilkan: Biji kakao kering ( $\mathrm{kg} /$ perlakuan) mewakili hasil panen kakao dalam analisis kami. Secara keseluruhan, kami meneliti 75.576 buah kakao di mana 4.071 buah dipanen dalam 28 putaran survei.

\section{Komunitas burung dan keberhasilan predasi burung}

Metode: Pada bulan September 2010 dan dari bulan Februari sampai dengan Juni 2011 (total 7 bulan dan kunjungan per lokasi), kami melakukan metode titik hitung (point count) dan jala kabut (mist netting sampling) bulanan untuk meneliti burung-burung di setiap lokasi penelitian (total: 15 kebun kakao). Metode titik hitung adalah metode yang didasarkan pada survei yang dilakukan dalam 20 menit di sepuluh titik di setiap kebun kakao (ukuran tempat survei 50x50 m), di mana burung diidentifikasi secara visual atau akustik (identifikasi suara burung). Pengambilan sampel dengan metode jala kabut didasarkan pada metode ilmiah terstandarisasi di mana burung ditangkap dengan jaring khusus burung yang kecil (total panjang jaring $48 \mathrm{~m}$ menggunakan 8 jaring burung berukuran $6 \times 3 \mathrm{~m}$ dengan ukuran lubang jaring $16 \mathrm{~mm}$ ). Kedua metode pengambilan sampel selalu dilakukan pada tanggal yang sama di setiap lokasi penelitian (Gbr. 6). 


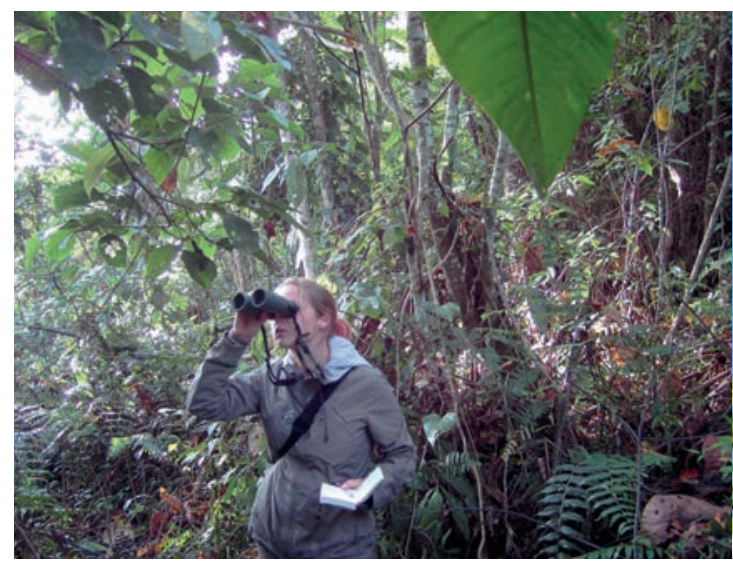

Fig. 6: The bird community was investigated using repeated point counts (left) and mist netting of birds (right). Photo credits: B. Maas

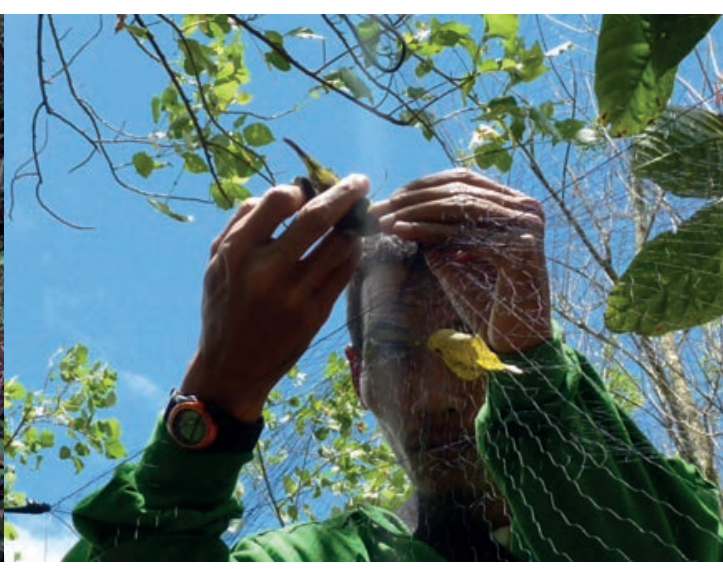

Gbr. 6: Komunitas burung diteliti dengan metode titik hitung (kiri) dan jala kabut (kanan) secara berulang. Foto: B. Maas

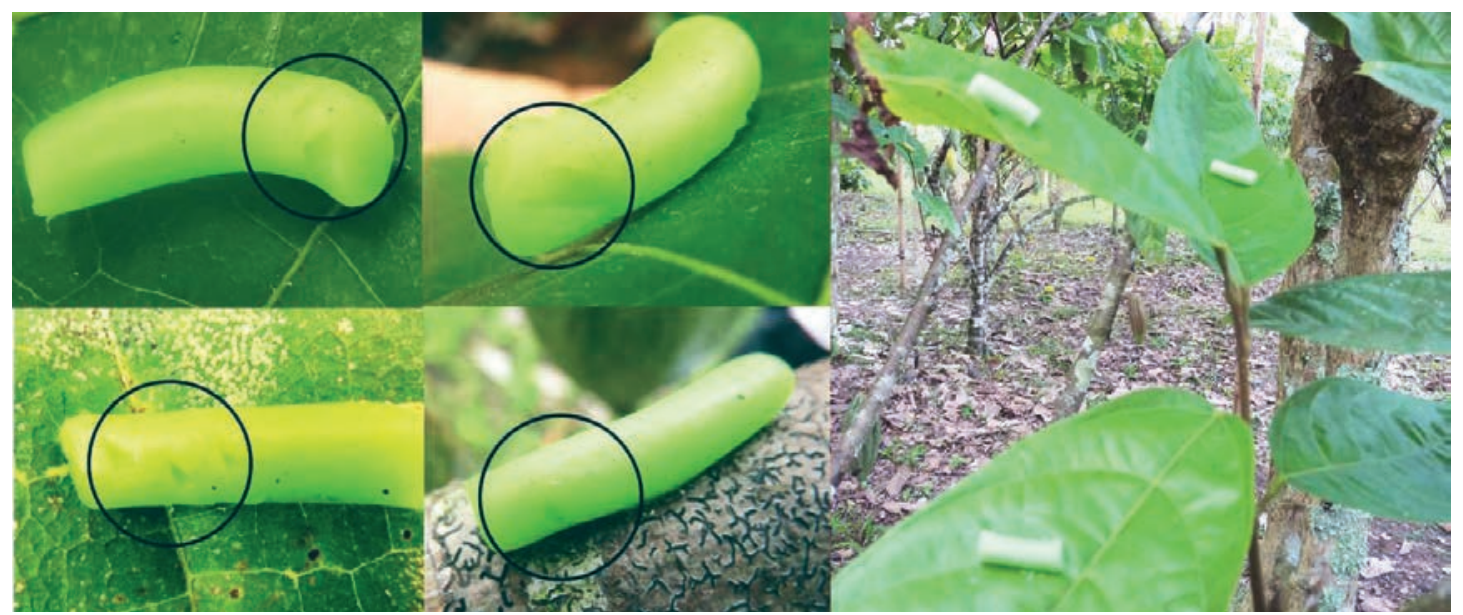

Fig. 7: Predation success of birds was quantified using plasticine caterpillars (imitating natural caterpillars; lengths: $2.5 \mathrm{~cm}$ ). These caterpillars could be applied to various positions on the cacao trees and bird predation marks (marked with black circles) could be identified. Photo credits: B.Maas
Gbr. 7: Keberhasilan predasi burung dikuantifikasi menggunakan ulat plastisin (meniru ulat sungguhan; panjang ulat: $2,5 \mathrm{~cm}$ ). Ulat-ulat ini diletakkan pada berbagai posisi di pohon kakao dan tanda predasi burung (digambar ditandai dengan lingkaran hitam) dapat diidentifikasi. Foto: B.Maas 
In addition, an "artificial prey experiment" was performed to investigate the predation activity within the plots between June and July 2011. For this experiment, we used "plasticine caterpillars" (Total of 10 study sites, 7 caterpillars on 5 study trees per site) to imitate the natural prey of birds (butterfly larvae). Bird predation marks can be identified and counted after some period of application at the study site. This way, we could quantify bird predation success on the different study sites.

To quantify the bird predation activity in our cacao agroforestry sites, we dispersed a total of 2,800 dummy caterpillars on the ten selected experimental sites and controlled them for predation marks after daytime predation activity (of birds) and night-time predation (of bats and rodents).

\section{Survey period and data output:}

The investigation of the bird community (point counts and mist netting) was conducted over 7 months, including 7 visits of each of our 15 cacao plantations. The "dummy caterpillar experiment" was conducted 4 times on each of the 10 selected study sites.

In total, we observed 69 bird species belonging to 36 families within the 15 smallholder cacao agroforestry systems. From this overall number of observed bird species, 38 species were caught with mist nets and 57 species were recorded with repeated point counts. The analysis of bird predation success focused on insect eating birds only (50 species).
Selain itu, "Eksperimen burung pemangsa buatan" dilakukan untuk mengetahui aktivitas predasi di dalam semua lokasi penelitian pada Juni dan Juli 2011. Untuk eksperimen ini, kami menggunakan "ulat plastisin" (dilakukan di 10 lokasi penelitian dengan 7 larva pada 5 pohon yang diteliti di tiap lokasi). Peletakan ulat dilakukan untuk meniru mangsa alami burung (larva kupu-kupu). Tanda-tanda predasi burung dapat diidentifikasi dan dihitung setelah beberapa periode peletakan ulat buatan di lokasi penelitian. Dengan cara ini, kami bisa mengukur keberhasilan predasi burung di lokasi penelitian yang berbeda.

Untuk mengukur aktivitas predasi burung di lokasi penelitian, kami menyebarkan 2.800 ulat palsu di sepuluh lokasi terpilih dan mengontrol mereka untuk aktivitas predasi siang hari (oleh burung) dan aktivitas predasi malam hari (oleh kelelawar dan tikus).

\section{Periode survei dan data yang dihasilkan:}

Penelitian terhadap komunitas burung (kombinasi metode titik hitung dan jala kabut) dilakukan selama 7 bulan, mencakup 7 kunjungan ke masingmasing 15 perkebunan kakao tempat penelitian. "Eksperimen ulat palsu” dilakukan 4 kali pada masing-masing 10 lokasi penelitian yang terseleksi.

Secara keseluruhan, kami mengamati 69 spesies burung yang termasuk dalam 36 famili dalam 15 sistem agroforestri kakao rakyat yang menjadi lokasi penelitian. Dari jumlah tersebut, 38 spesies tertangkap dengan jaring burung dan 57 spesies tercatat dengan metode titik hitung. Analisis keberhasilan predasi burung difokuskan pada burung pemakan serangga saja (50 spesies). 


\section{Herbivory (leaf damage) by leaf eating (pest) insects}

Method: On each study tree, leaf damage (in \%) caused by plant eating insects (e.g. beetles, caterpillars) was quantified. Every month, we marked a new group of 10 young cacao leaves on each study tree and surveyed them three times (every 10 days) to investigate leaf growth and leaf damage.

Survey period and data output: In total, we investigated 34,400 leaves in 30 visits per site (survey rounds) between from June 2010 until June 2011.

\section{Cacao study trees}

All 120 cacao study trees were completely measured (e.g. tree height; canopy area; local shade cover) in 2010 and 2011 to investigate tree growth and canopy extension.

\section{Rain data (precipitation)}

From June 2010 until April 2011, we were collecting rain data on 7 different study locations in Napu (cooperation with Dr. Iris Motzke from Göttingen University). These data were connected with all other data sets in the statistical analysis of our results.

\section{Cacao age and fruit development (side study)}

Method: To be able to connect cacao size classes to approximate age values, we conducted a small side study on cacao fruit development and cacao age. For this study, we marked 400 young cacao

\section{Kerusakan daun oleh serangga pemakan daun (hama)}

Metode: Di setiap pohon penelitian (jumlah: 120 pohon), kami menghitung persentase kerusakan daun oleh serangga pemakan daun (misalnya kumbang dan larva kupu-kupu). Setiap bulan, kami menandai 10 daun muda di setiap pohon yang diteliti dan mengamatinya tiga kali (setiap 10 hari) untuk menyelidiki pertumbuhan daun dan kerusakan daun.

Periode survei dan data yang dihasilkan: Secara keseluruhan, kami menyelidiki 34,400 daun dalam 30 kunjungan per lokasi (putaran survei) selama Juni 2010 sampai Juni 2011.

\section{Pohon kakao yang diteliti}

Sebanyak 120 pohon kakao yang diteliti diukur (misalnya tinggi pohon, area kanopi, pohon naungan) pada tahun 2010 dan 2011 untuk menyelidiki pertumbuhan pohon dan perpanjangan kanopi.

\section{Curah hujan (presipitasi)}

Dari bulan Juni 2010 sampai April 2011, kami mengumpulkan data curah hujan di 7 lokasi penelitian yang berbeda di Napu (bekerjasama dengan Dr. Iris Motzke dari Universitas Göttingen). Data ini terkait dengan semua data lain dalam analisis statistik hasil penelitian ini.

\section{Usia kakao dan perkembangan buah (penelitian sampingan)}

Metode: Untuk dapat mengaitkan kelas-kelas ukuran kakao dengan perkiraan usia buah, kami melakukan penelitian kecil pada perkembangan buah kakao dan usia kakao. Untuk penelitian ini, kami menandai 400 buah kakao muda (panjang 


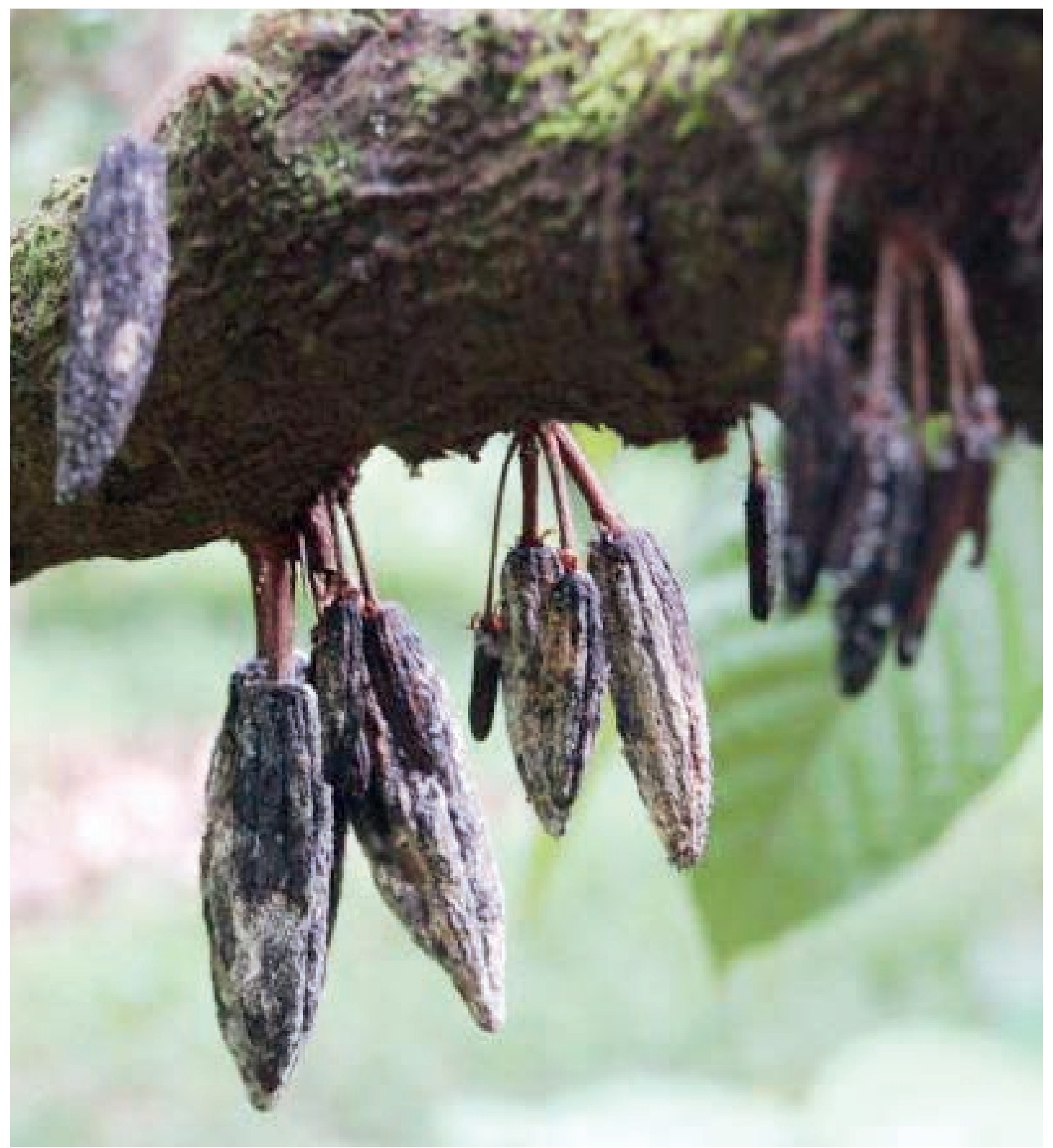

Fig. 8: The cacao tree only develops a small proportion of all fruits that start development. Some fruit get naturally aborted by the tree ("Cherelle Wilt") to the benefit of the other fruits.Photo credit: B.Maas
Gbr. 8: Pohon kakao hanya mengembangkan sebagian kecil dari semua buah yang mulai tumbuh. Beberapa buah mengalami aborsi alami ("Cherelle Wilt") untuk kepentingan buah lainnya. Foto: B. Maas 
fruits (lengths below $8 \mathrm{~cm}$ ) with individual numbers and followed their development until harvest.

This way, we could connect fruit size classes with approximate fruit age. This side study also provides information on the productivity. Usually, cacao trees do not fully develop all fruits which are built on the tree. Only few fruits are fully developed. Most other fruits are aborted by the tree (scientific name for this syndrome: "Cherelle Wilt"). Cherelle Wilt is a natural reaction of the tree and no disease (see Fig. 8).

Survey period and data output: The study started in May 2010 and ended with the last harvested fruit in October 2010. In total 69 of all marked fruit became ripe and could be harvested. The other $31 \%$ were lost because of "Cherelle Wilt" (natural abortion) or cacao diseases. kurang dari $8 \mathrm{~cm}$ ) dengan nomor individual dan mengikuti perkembangan buah-buah tersebut sampai masa panen.

Dengan cara ini, kami bisa mengaitkan kelas ukuran buah kakao dengan perkiraan usia buah. Penelitian sampingan ini juga memberikan informasi mengenai produktivitas buah. Biasanya, tidak semua buah yang tumbuh di atas pohon dapat berkembang. Hanya beberapa buah yang dapat berkembang. Sebagian besar buah lainnya diaborsi oleh pohon itu sendiri (nama ilmiah untuk sindrom ini: "Cherelle Wilt"). Cherelle Wilt merupakan reaksi alami pohon dan bukan penyakit (lihat Gbr. 8).

\section{Periode survei dan data yang dihasilkan:}

Penelitian ini dimulai pada Mei 2010 dan berakhir pada panen terakhir di bulan Oktober 2010. Secara keseluruhan, ada 69 buah yang ditandai yang matang dan bisa dipanen. Sebanyak 31\% buah tidak bisa dipanen karena "Cherelle Wilt" (aborsi alami) atau penyakit kakao. 



\section{Research Results}

\section{Insects and spiders}

In total, we observed 47,406 day-active and night-active insects and spiders belonging to 16 orders and 65 families, from which 32,537 individuals from eight target arthropod orders (from at least 46 families) were included in our analyses (see Table 1).

All orders of insects and spiders increased in the absence of birds, bats or the predator was in our treatment. From 8 arthropod orders that were within the focus of our analysis, there are species that could have a negative effect on crop yields of cocoa (insect pests, for example larvae of butterflies and beetles, aphids, grasshoppers are eating the leaves and flowers; see Fig. 9) and there are also species that contribute to the reduction of insect pests (e.g. "mesopredator species" such as ants and spiders that eat insects).

\section{Hasil Penelitian}

\section{Serangga dan laba-laba}

Secara keseluruhan, kami mengamati 47.406 individu serangga dan laba-laba yang aktif pada siang dan malam hari yang termasuk dalam 16 ordo dan 65 famili. Dari jumlah ini, 32.537 individu termasuk 8 ordo arthropoda (sedikitnya dari 46 famili) yang dimasukkan dalam analisis kami (lihat Tabel 1).

Semua ordo serangga dan laba-laba meningkat dalam ketidakhadiran burung, kelelawar atau kedua pemangsa itu di perlakuan kami. Dari 8 ordo yang menjadi fokus analisis dalam penelitian ini, ada spesies yang memberi efek negatif pada hasil panen kakao (serangga hama; misalnya larva kupu-kupu dan kumbang, kutu daun, belalang yang makan daun dan bunga; lihat Gbr. 9) dan ada juga spesies yang berkonstribusi pada penurunan jumlah serangga hama (misalnya “mesopredator spesies" seperti semut dan labalaba yang memakan serangga). 
Tabel 1:

Arthropod numbers on the different part of cacao trees and during dayand night-surveys.
Tabel 1:

Jumlah arthropoda di berbagai

bagian pohon kakao pada saat

survei siang dan malam.

\begin{tabular}{l|l|l|l|l|l|l|l|l}
\hline & \multicolumn{7}{|c}{$\begin{array}{c}\text { Sum of insects and spiders } \\
\text { Jumlah serangga dan laba-laba }\end{array}$} \\
\hline $\begin{array}{l}\text { Sum of } \\
\text { individuals }\end{array}$ & $\begin{array}{l}\text { Butterfly } \\
\text { larvae }\end{array}$ & Beetles & Ants & Spiders & $\begin{array}{l}\text { Larvae } \\
\text { (total) }\end{array}$ & Aphids & $\begin{array}{l}\text { Grass- } \\
\text { hoppers }\end{array}$ & $\begin{array}{l}\text { Cock- } \\
\text { roaches }\end{array}$ \\
\hline $\begin{array}{l}\text { Jumlah } \\
\text { individu }\end{array}$ & $\begin{array}{l}\text { Larva } \\
\text { Kupu- } \\
\text { kupu }\end{array}$ & Kumbang & Semut & $\begin{array}{l}\text { Laba- } \\
\text { laba }\end{array}$ & $\begin{array}{l}\text { Larva } \\
\text { (total) }\end{array}$ & $\begin{array}{l}\text { Kutu } \\
\text { daun }\end{array}$ & Belalang & Kecoak \\
\hline $\begin{array}{l}\text { (a) } \\
\text { woody parts } \\
\text { bagian berkayu }\end{array}$ & 486 & 1101 & 9711 & 3580 & 540 & 1343 & 97 & 374 \\
\hline $\begin{array}{l}\text { (b) } \\
\text { cacao leaves } \\
\text { daun kakao }\end{array}$ & 1973 & 2469 & 1047 & 1330 & 2514 & 5704 & 250 & 18 \\
\hline $\begin{array}{l}\text { (II) } \\
\text { day active } \\
\text { aktif siang hari }\end{array}$ & 1665 & 2062 & 9367 & 3228 & 2090 & 5352 & 108 & 162 \\
\hline $\begin{array}{l}\text { (II) } \\
\text { night active } \\
\text { aktif malam hari }\end{array}$ & 794 & 1508 & 1391 & 1682 & 964 & 1695 & 239 & 230 \\
\hline $\begin{array}{l}\text { Total } \\
\text { Tala }\end{array}$ & $\mathbf{2 4 5 9}$ & $\mathbf{3 5 7 0}$ & $\mathbf{1 0 7 5 8}$ & $\mathbf{4 9 1 0}$ & $\mathbf{3 0 5 4}$ & $\mathbf{7 0 4 7}$ & $\mathbf{3 4 7}$ & $\mathbf{3 9 2}$ \\
\hline
\end{tabular}

Fig. 9: Overview of arthropod groups (beetles, butterfly larvae ants and spiders) that became more abundant due to the absence of birds and bats. Scientific names are given below the pictures (showing most common species or family within each arthropod group) Photo credits: indicated inside the picture - other credits belong to B.Maas

Gbr. 9: Gambaran umum kelompok artropoda (kumbang, semut, larva kupu-kupu dan laba-laba) yang menjadi lebih melimpah karena tidak adanya burung dan kelelawar. Nama ilmiah ada di bawah gambar (menunjukkan spesies dan famili yang paling umum dalam setiap kelompok artropoda). 
Beetles Kumbang

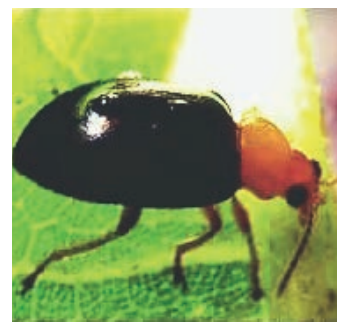

Chrysomelidae

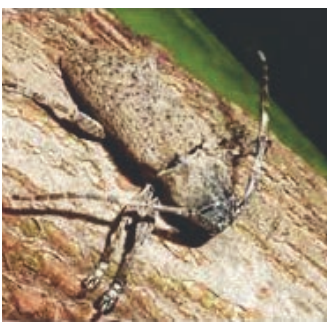

Cerambycidae

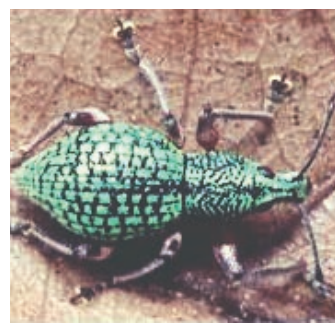

Curculionidae

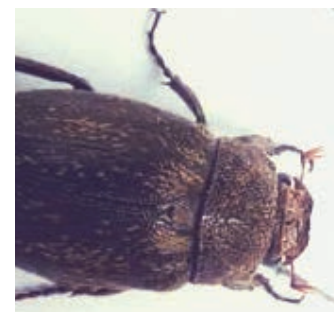

Scarabeidae

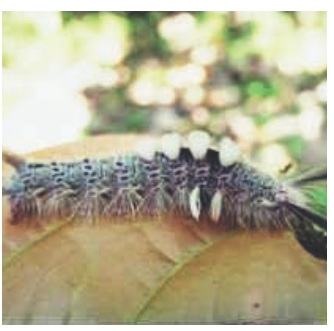

Lymantriidae

Geometridae

Limacodidae

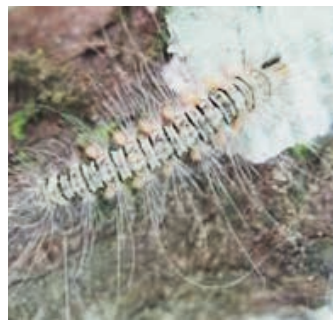

Arctiidae

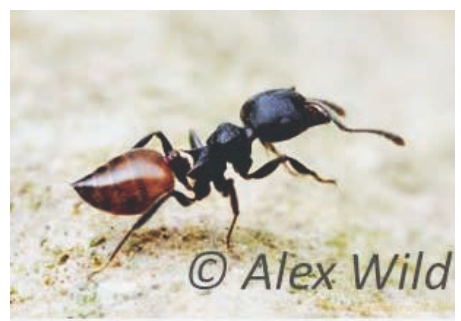

Crematogaster sp.

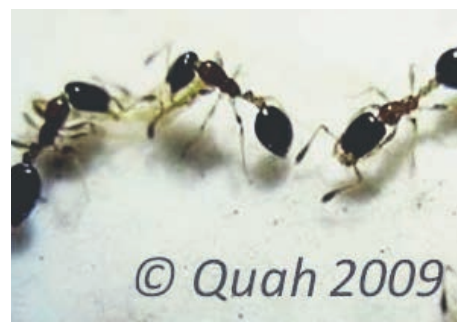

Monomorium floricola

Anoplolepis gracilipes

\section{Spiders Laba-laba}

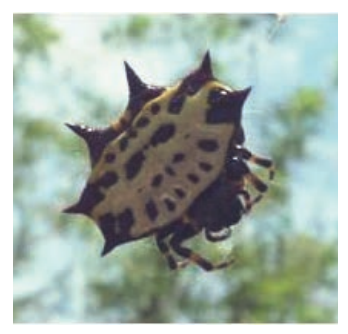

Araneidae

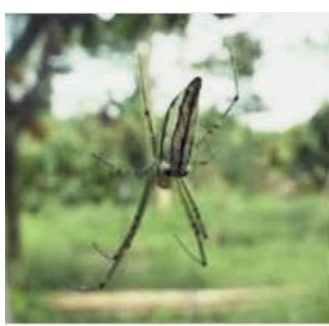

Tetragnathidae

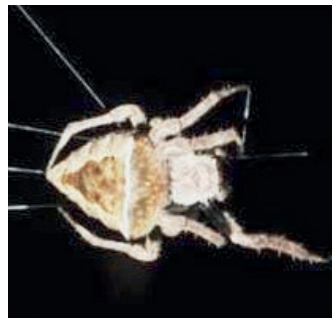

Uloboridae

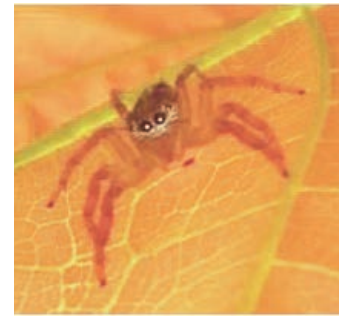

Salticidae 


\section{Cacao fruit development and cacao diseases}

As a result of our long-term exclosure experiment, there was no significant increase of cacao diseases. We recorded the incidence of the cacao bug (scientific name: Helopeltis sulawesi) Cacao Pod Borer infections (scientific name: Conopomorpha cramerella) and incidence of Black Pod Disease (caused by different fungi; scientific name: Phytophthora spp.; Indonesian: penyakit busuk buah) as well as the occurrence of natural fruit abortion (scientific name: Cherelle Wilt).

There was no significant effect on cacao disease incidence by the exclosure experiment. Accordingly, the number of fruit pests did not change because of the absence of birds and bats. A possible explanation could be that fruit pest incidence was still controlled by ants, which were not excluded from our study trees. Previous studies have shown, that ants can have strong positive effects on cacao fruit development and that they minimize the risk of cacao fruit pests (Wielgoss et al., 2012). The results from Dr. Arno Wielgoss (S3 ant study on cacao systems in Palolo) also showed, that the reduction of one pest can enhance the incidence of another pest (the reduction of Helopeltis sulawesi lead to an increased infection rate by Conopomorpha cramerella). He also showed (Wielgoss et al., 2014) that ants can be beneficial for cacao production on the one hand (by reducing the incidence of some cacao diseases), but that they can also provide disservices (negative effects) because some species enhance the numbers of plant sucking insects (mealybugs), which are causing damage to cacao fruit development and cacao yield (Maas et al., 2013).

\section{Perkembangan buah kakao dan penyakit buah}

Sebagai hasil dari eksperimen exclosure jangka panjang kami, tidak ada peningkatan penyakit kakao yang signifikan. Kami mencatat kejadian serangan hama kepik kakao (nama ilmiah: Helopeltis sulawesi. Infeksi penggerek polong kakao (nama ilmiah: Conopomorpha cramerella) dan kejadian penyakit busuk buah (disebabkan oleh jamur berbeda, nama ilmiah: Phytophthora spp.), dan juga terjadinya aborsi buah secara alami (nama ilmiah: Cherelle Wilt).

Tidak ada pengaruh signifikan terhadap kejadian penyakit kakao yang disebabkan oleh eksperimen exclosure. Dengan demikian, jumlah hama buah tidak berubah karena ketiadaan burung dan kelelawar. Penjelasan yang mungkin adalah bahwa kejadian hama buah masih dikendalikan oleh semut, yang tidak ditiadakan dari pohon yang diteliti. Penelitian-penelitian sebelumnya menunjukkan bahwa semut memiliki efek positif yang kuat pada perkembangan buah kakao dan meminimalkan risiko hama buah kakao (Wielgoss dkk., 2012). Hasil penelitian Dr. Arno Wielgoss (penelitian S3 pada semut di tanaman kakao di Palolo) juga menunjukkan bahwa pengurangan satu hama dapat meningkatkan kejadian hama lain (pengurangan Helopeltis sulawesi menyebabkan tingkat infeksi Conopomorpha cramerella meningkat). Ia (Wielgoss $d k k$., 2014) juga menunjukkan bahwa semut dapat bermanfaat untuk produksi kakao (dengan mengurangi kejadian beberapa penyakit kakao), tetapi mereka juga dapat memberikan akibat negatif karena beberapa spesies meningkatkan spesies serangga hama (misal: kutu daun, nama ilmiah: Aphididae), yang menyebabkan kerusakan pada perkembangan buah kakao dan hasil panen kakao (Maas dkk., 2013). 


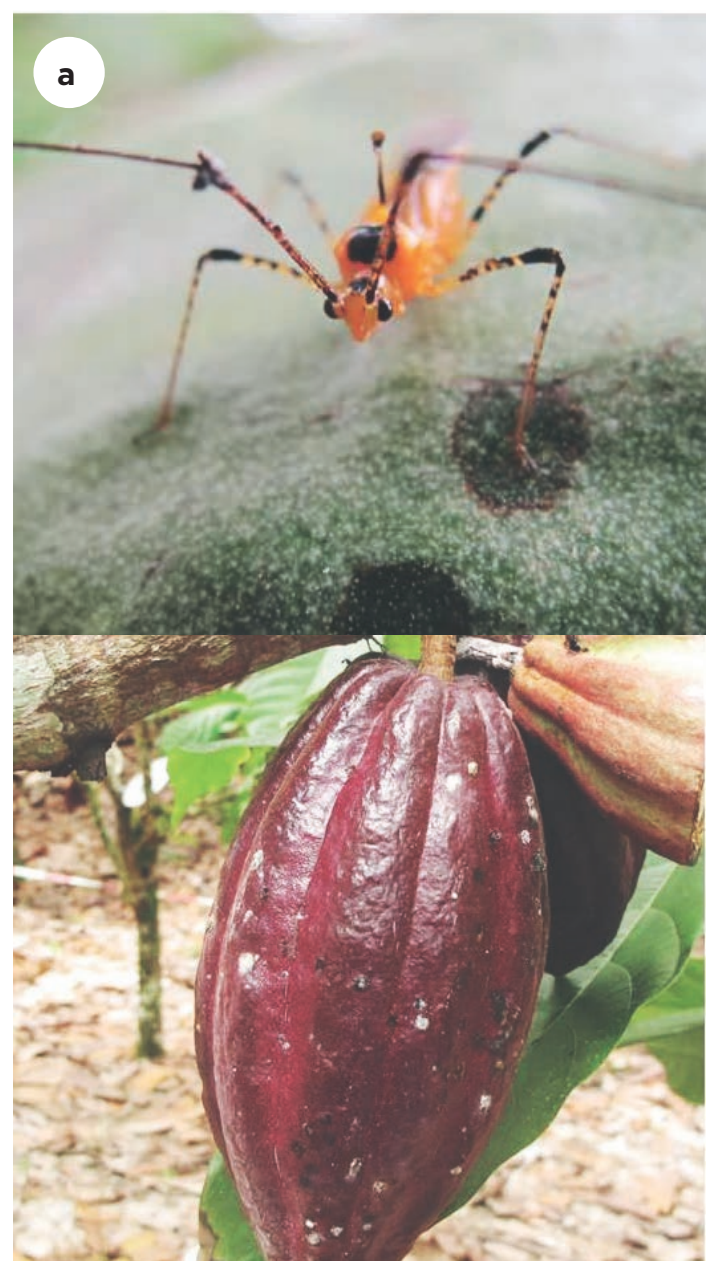

Fig. 10: Different species within cacao plantations often show strong interactions. This is also true for cacao crop diseases like:

(a) Helopeltis sulawesii and

(b) Conopomorpha cramerella.

Studies show, that the reduction of H. sulawesii can enhance the incidence of an even more serious cacao pest: Conopomorpha cramerella (Wielgoss et al. 2012). Accordingly, intermediate densities of $H$. sulawesii might be less harmful for cacao productivity than very low densities.

Photo credits: Arno Wielgoss.

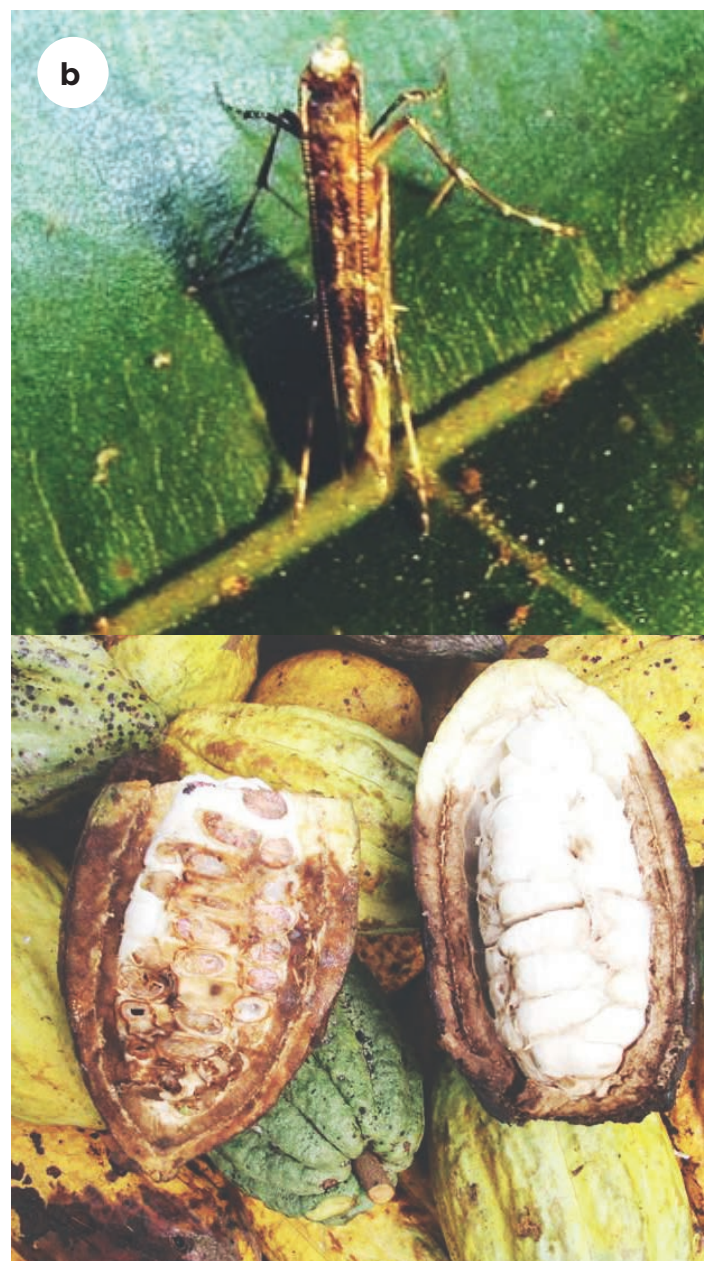

Gbr.10: Jenis hama yang berbeda di perkebunan kakao sering menunjukkan interaksi yang kuat. Hal ini juga berlaku untuk hama tanaman kakao seperti:

(a) Helopeltis sulawesii dan

(b) Conopomorpha cramerella.

Penelitian menunjukkan bahwa pengurangan hama H. sulawesii dapat meningkatkan insiden hama kakao yang lebih serius yaitu Conopomorpha cramerella (Wielgoss, dkk., 2012). Karena itu, kepadatan sedang Helopeltis sulawesii mungkin tidak terlalu berbahaya untuk produktivitas kakao daripada jika kepadatannya sangat rendah.

Foto: Arno Wielgoss. 


\section{Bird community and bird predation success}

In total, we observed 69 bird species belonging to 36 families within the 15 smallholder cacao agroforestry systems. The majority of all birds were represented by insect eating bird species (71\%). Bird species with no specific habitat preference account for the half (50\%), while open land species make up 30\% and forest species $17 \%$ of the bird community. Almost a third of the species (27\%) were endemic (they only occur in Sulawesi and nowhere else in the world) whereas the remaining 50 species $(71.43 \%)$ were widespread.

The results from our statistical analysis (connecting results from bird community surveys and the predation experiment) showed, that predation success (on our plasticine caterpillars applied during the experiment) was dominated by the most abundant species in our study area, the Yellow-Bellied White-Eye (scientific name: Zosterops chloris; Indonesian: Kacamata Laut).

This bird species contributed most to the predation on the plasticine caterpillars on our sites. Butterfly larvae are one the most serious pest insects groups in tropical agroforestry systems like cacao and coffee (Mols and Visser 2002) and their regulation by pest control is therefore a highly valuable service from which smallholder plantation owners can profit.

Accordingly, our recommendation to farmers is to support the presence of this bird species (and other insect eating bird species) in their plantations and to disturb them as less as possible.

\section{Komunitas burung dan keberhasilan predasi burung}

Secara keseluruhan, kami mengamati 69 jenis burung dari 36 famili di 15 kebun kakao di lokasi penelitian kami. Jenis burung yang paling dominan adalah burung pemakan serangga (71\%). Spesies burung yang tidak memiliki preferensi habitat yang spesifik ditemukan sebanyak setengah (50\%), sedangkan 30\% memiliki preferensi lahan terbuka dan $17 \%$ adalah spesies yang hidup di hutan. Hampir sepertiga dari semua jenis burung (27\%) adalah spesies endemik (mereka hanya ada di Sulawesi dan tidak ada di tempat lain di dunia) sedangkan 50 spesies sisanya $(71,43 \%)$ tersebar lebih luas.

Hasil analisis statistik kami (mengaitkan hasil dari survei komunitas burung dan eksperimen predasi) menunjukkan bahwa keberhasilan predasi (pada ulat plastisin yang diletakkan selama eksperimen) didominasi oleh spesies yang paling melimpah di lokasi penelitian kami: burung kacamata laut (nama ilmiah: Zosterops chloris).

Jenis burung ini memberikan kontribusi paling besar terhadap predasi ulat plastisin di lokasi penelitian kami. Larva kupu-kupu adalah satu kelompok serangga hama yang paling serius dalam sistem pertanian agroforestri tropis seperti kakao dan kopi (Mols dan Visser, 2002) dan pengendalian jumlah kelompok ini adalah jasa yang sangat berharga dan dapat menguntunkan pemilik perkebunan.

Oleh karena itu, kami merekomendasikan petani kakao untuk mendukung keberadaan spesies burung ini (dan jenis burung pemakan serangga lain) di perkebunan mereka dan sebisa mungkin tidak mengganggu jenis burung tersebut. 
In the following, some pictures of insect eating bird species are provided:

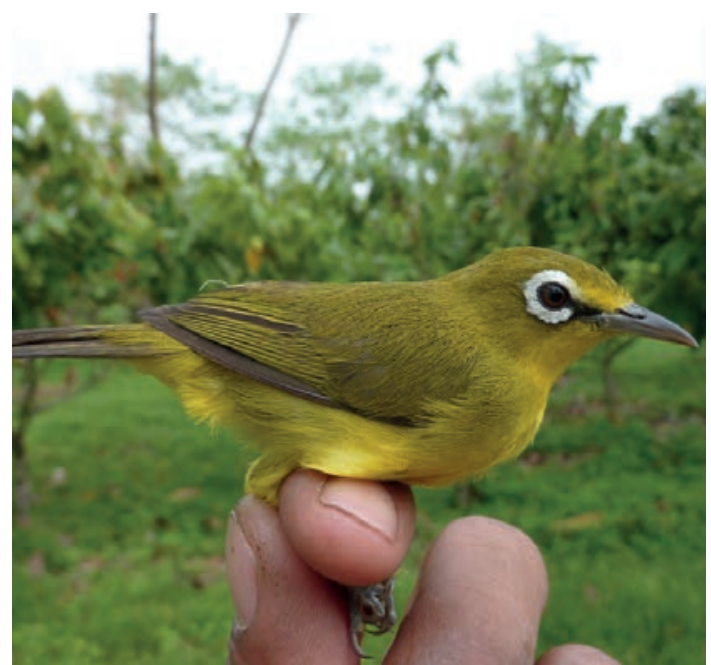

\section{Zosterops chloris}

Lemon-bellied white-eye

Kacamata Laut

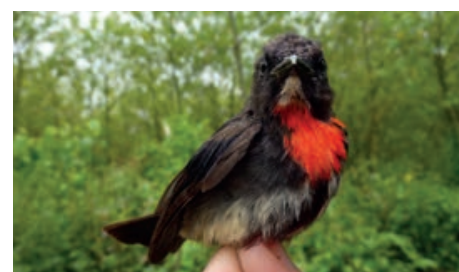

Dicaeum celebicum

Grey-sided flowerpecker

Cabai panggul kelabu

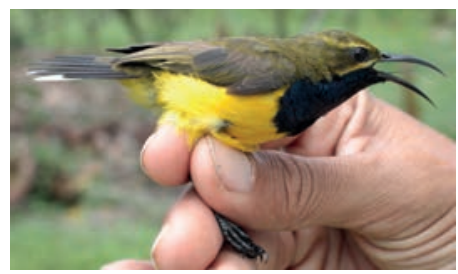

Nectarinia jugularis

Olive-backed sunbird

Burung madu sriganti
Berikut ini, kami sajikan beberapa gambar jenis burung pemangsa serangga:

Fig. 11: The six most common insect eating bird species (out of 50 species; scientific and common names provided) that were observed on the cacao plantation sites during our study. These species provide very important services because they reduce the number of insects (also pest insects) and therefore contribute to an enhance cacao production. Photo credits: B. Maas

Gbr. 11: Enam spesies burung pemakan serangga (dari 50 spesies; beserta ama ilmiah dan nama umumnya) yang teramati di lokasi perkebunan kakao selama penelitian kami. Spesies ini menyediakan jasa yang sangat penting karena mereka mengurangi jumlah serangga (juga serangga hama) dan dengan demikian berkontribusi terhadap peningkatkan produksi kakao. Foto: B. Maas

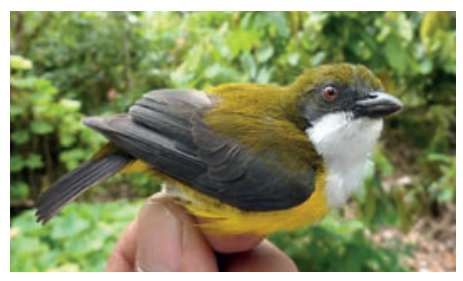

\section{Dicaeum aureolimbatum} Yellow-sided flowerpecker Cabai panggul kuning

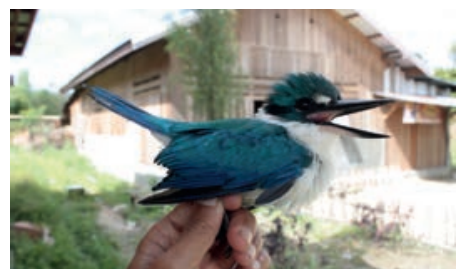

Halcyon chloris

Collared kingfisher Cekakak sungai

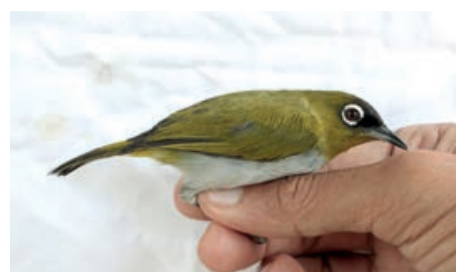

Zosterops atrifrons

Black-crowned white-eye Kacamata dahi hitam 
ब这

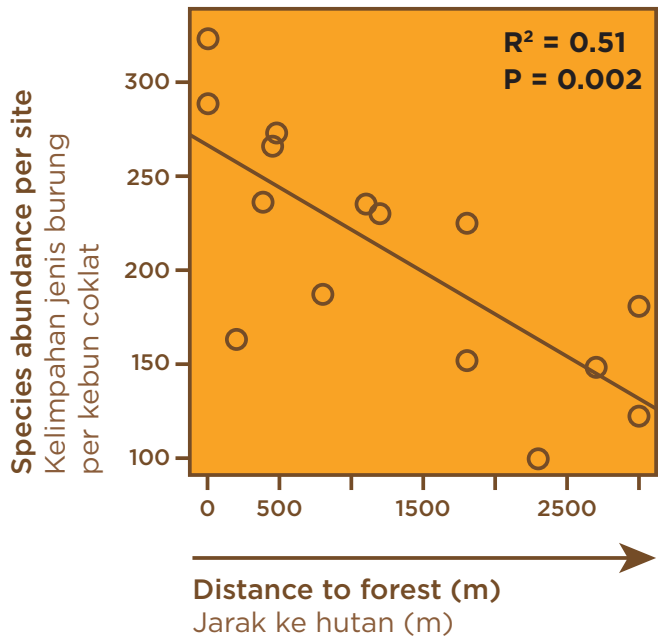

Fig. 12: The proximity of natural forest enhances the abundance of insect eating bird species (left side) as well as the predation services they are providing (reduction of pest insects species like caterpillars, which were imitated in this experiment; see right side). - for reference see Maas et al., (2015b), Journal of Applied Ecology

\section{Herbivory (leaf damage) by leaf eating (pest) insects}

Similar to the incidence of cacao fruit pests, also the leaf damage on our cacao study trees did not change significantly during our experiment. Accordingly, the absence of birds and bats had no negative effects on the foliage of cacao.

\section{Cacao age and fruit development}

Although the incidence of cacao fruit pests (e.g. Cacao Pod Borer, Black Pod Disease; Helopeltis sulawesi) and the amount of leaf damage did not change during our experiment, we found profound effects of the absence of
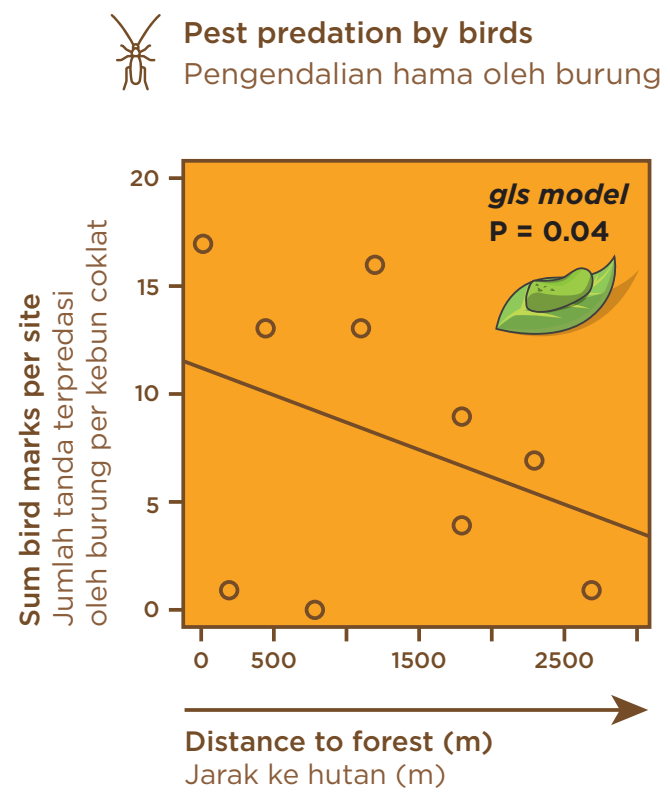

Gbr. 12: Jarak dengan hutan primer mendukung kelimpahan jumlah burung pemakan serangga (gambar kiri) dan jasa yang diberikan (pengurangan serangga hama seperti ulat, seperti ditiru dalam eksperimen ini; lihat gambar kanan). Untuk referensi lihat publikasi dari Maas dkk., (2015), Journal of Applied Ecology

\section{Kerusakan daun oleh serangga (hama) pemakan daun}

Serupa dengan kejadian hama buah kakao, kerusakan daun pada pohon kakao yang diteliti juga tidak berubah secara signifikan selama eksperimen. Oleh karena itu, tidak adanya burung dan kelelawar tidak memiliki efek negatif pada daun kakao.

\section{Usia kakao dan perkembangan buah}

Meskipun kejadian hama buah kakao (misalnya kerusakan karena penggerek polong kakao, penyakit busuk buah, dan Helopeltis sulawesi) dan jumlah kerusakan daun tidak berubah selama eksperimen, kami menemukan efek 
birds and bats (respectively the absence of the predation services they provide) on cacao fruit development and cacao yield.

Our results show, that in consequence of bird and bat absence, the cacao crop yield will decrease. This development can be observed already in the early stage of cacao development (reduced number of cacao flowers), as well as in all later stages of the fruit development (number of fruits) and finally affects the crop yield.

The results of our 2-year study show, that birds and bats save more than $31 \%$ of the cacao crop yield because of the predation services they provide (reduction of pest insects). Our study shows that crop yield will decrease by $31 \%$ if birds and bats are absent (e.g. possible because of decreasing natural habitat; loss of forest area and land use intensification into monoculture systems). This effect corresponds to USD 730/ ha/a or IDR 8,6 million/ha/a (per one ha cacao and one year cacao production) which are saved because of the presence of birds and bats that act as natural enemies of pest insects in the plantation.

The effect of cacao yield increase because of the bird and bat predation ecosystem service occurs across the local and landscape gradients we applied in our study (local shade tree availability and distance to forest).

However, local shade tree density can enhance the density of insect eating bird species (e.g. Rice and Greenberg 2000; Perfecto et al., 2007; Tscharntke et al,. 2011) as well as close proximity yang sangat jelas dari tidak adanya burung dan kelelawar (dan tidak adanya jasa predasi yang mereka berikan) pada perkembangan buah dan hasil panen kakao.

Hasil penelitian kami menunjukkan bahwa sebagai konsekuensi dari akibat tidak adanya burung dan kelelawar, hasil panen kakao akan menurun. Perkembangan ini dapat diamati sejak tahap awal perkembangan kakao (pengurangan jumlah bunga kakao), serta dalam semua tahap perkembangan buah selanjutnya (jumlah buah) dan akhirnya mempengaruhi hasil panen kakao.

Hasil dari penelitian kami selama dua tahun menunjukkan bahwa burung dan kelelawar menyelamatkan lebih dari $31 \%$ hasil panen kakao karena jasa predasi yang mereka berikan (pengurangan serangga hama). Penelitian kami menunjukkan bahwa hasil panen akan menurun 31\% jika tidak ada burung dan kelelawar (kemungkinan penyebab: pengurangan habitat alami; hilangnya kawasan hutan dan intensifikasi lahan secara monokultur). Pengaruh ini setara dengan sekitar USD 730 atau Rp8,6 juta per ha per tahun yang diselamatkan karena kehadiran burung dan kelelawar yang bertindak sebagai musuh alami serangga hama di perkebunan.

Pengaruh peningkatan hasil panen kakao karena jasa ekosistem berupa predasi burung dan kelelawar terjadi di seluruh gradien lokal dan lanskap yang diterapkan dalam penelitian ini (ketersediaan pohon naungan di dalam kebun dan jarak ke hutan primer).

Meskipun demikian, kepadatan pohon naungan di dalam perkebunan kakao dapat meningkatkan kepadatan burung pemakan serangga (Rice dan Greenberg, 2000; Perfecto dkk., 2007; 


\section{$31 \%$}

= 730 USD/ha/year

= Rp8,6 juta/ha/tahun

\section{Harvested cacao yield decreased by $31 \%$ because of the absence of birds and bats}

Penurunan hasil panen kakao sebesar 31\% sebagai akibat dari tidak adanya burung dan kelelawar.

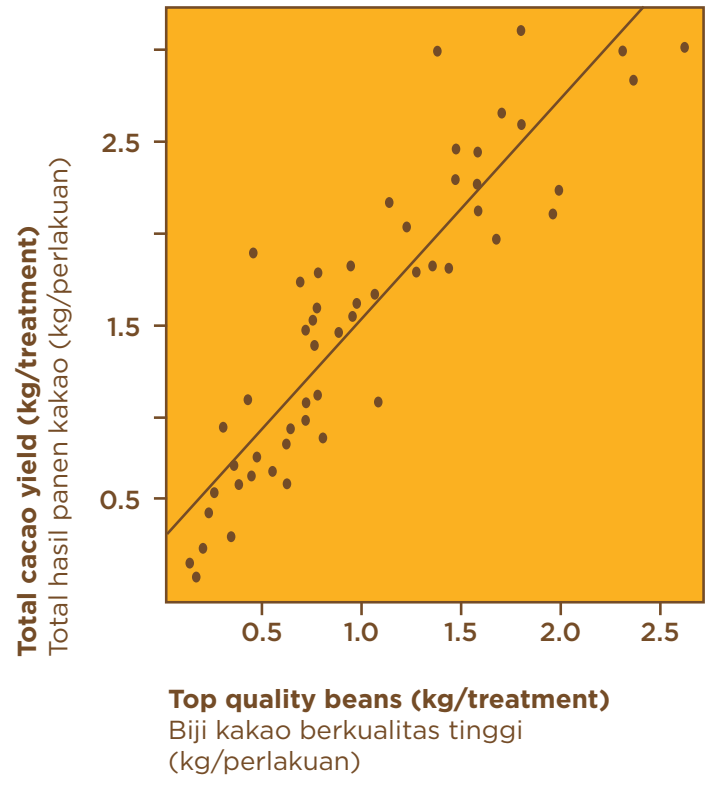

Fig. 13: Our study shows that the absence of birds and bats leads to a decrease of cacao production by $31 \%$. The quality of the cacao yield is also highly correlated to this result (see above, left side). To investigate not only cacao yield quantity but also yield quality, we separated high and low quality seeds in our experiment (see above, right side).

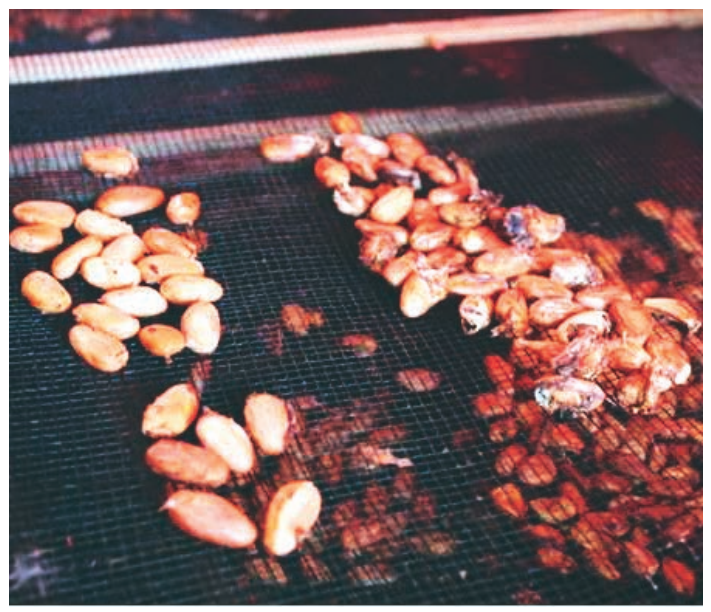

»Quality is decreasing Kualitas kakao menurun

» Number of Cacao flowers is decreasing Jumlah bunga dan buah menurun

Gbr. 13: Penelitian kami menunjukkan bahwa ketidakhadiran burung dan kelelawar menyebabkan penurunan produksi kakao sebesar 31\%. Kualitas hasil panen kakao juga berkorelasi tinggi dengan hasil ini (lihat gambar di atas, sisi sebelah kiri). Untuk meneliti hasil tidak hanya kuantitas tapi juga kualitas hasil panen kakao, kami memisahkan biji kakao berkualitas tinggi dan lebih rendah dalam eksperimen kami (lihat gambar di atas, sisi sebelah kanan). 
to forest supports higher densities of bird species (this study; Clough et al., 2009 and 2011).

Extensive agroforestry management can be very attractive to smallholder farmers if high crop production can be combined with high biodiversity (Clough et al., 2011). Furthermore, intensive agriculture management (including pesticides, fertilizer and shade tree pruning) can reduce the ability of ecosystems to provide goods and services, for example through degraded soil and water quality (Tilman et al., 2002).
Tscharntke dkk., 2011). Sama dengan hal tersebut, jarak yang dekat dengan hutan primer mendukung tingginya kepadatan jenis burung (penelitian ini; Clough dkk., 2009 dan 2011).

Manajemen pertanian agroforestri secara ektensif bisa sangat menarik bagi petani kecil jika produksi tanaman yang tinggi dapat dikombinasikan dengan keragaman hayati yang tinggi (Clough $d k k$., 2011). Selain itu, manajemen pertanian intensif (termasuk penggunaan pestisida, pupuk dan pemangkasan pohon naungan) dapat mengurangi kemampuan ekosistem untuk menyediakan barang dan jasa, misalnya menyebabkan degradasi tanah dan kualitas air (Tilman $d k k$., 2002).

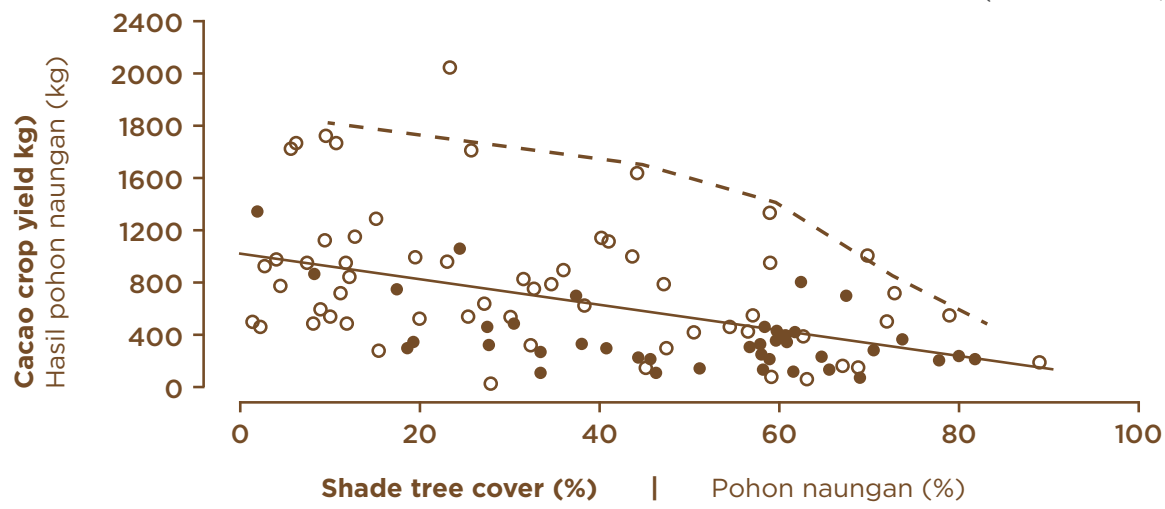

Fig. 14: Previous research has shown that high species diversity and high cacao harvest, can be combined. Left side: In agroforestry plants in Central Sulawesi (cacao), it may be possible to combine a high number of species with high yields (other agroforestry crops in Europa). In Sulawesi, many species of predators (including birds, bats and ants) provide a very important service because they can reduce the number of insect pests and therefore contribute to increase the production of cacao. Right side: Dashed lines represent the recorded data from the field. The solid line is the result of optimum cacao yield based models SUCROS-cacao (statistical models). According to the study, shade under 30\% or $40 \%$ is associated with high biodiversity gains, while only marginal yield losses occur. The graph is adapted from Clough et al. (2011).

Gbr.14: Penelitian sebelumnya telah menunjukkan bahwa keragaman spesies yang tinggi dan hasil panen kakao yang tinggi dapat dikombinasikan. Kiri: Di perkebunan agroforestri di Sulawesi Tengah (kakao), keragaman spesies yang tinggi dapat kombinasikan dengan hasil panen yang tinggi (tanaman agroforestri lainnya di Eropa). Di Sulawesi, banyak spesies pemangsa (termasuk burung, kelelawar dan semut) menyediakan jasa yang sangat penting karena mereka bisa mengurangi jumlah serangga hama dan dengan demikian berkontribusi terhadap peningkatkan produksi kakao. Kanan: Garis putus-putus mewakili data lapangan. Garis utuh merupakan hasil optimum panen kakao berdasarkan model SUCROS-kakao (model statistika). Menurut hasil penelitian ini, tingkat naungan di bawah 30\% atau 40\% berhubungan dengan keuntungan keragaman hayati yang tinggi, di mana yang terjadi hanya kehilangan hasil panen marjinal (marginal yield losses). Grafik diadaptasi dari Clough dkk., (2011). 



\section{Conclusions and \\ Management Recommendations}

\section{Birds and bats enhance cacao crop yield}

Our study highlights the economic importance of birds and bats providing effective ecosystem services such as natural pest control of insect pests in cacao agroforestry systems. The presence of birds and bats leads to an enhancement of cacao crop yield of at least $31 \%$ in our study area.

This strong economic impact suggests that natural predation of pest insects by birds and bats should be included in cacao agroforestry management to provide sustainable management methods that have positive effects on the smallholder economics. Bird and bats populations should be supported in cacao agroforestry to support their ecological functions.

This could be realized by increasing numbers of shade tree species (Clough et al., 2011; Tscharntke et al., 2011), exposing roosting/ nesting boxes for birds and bats (Morrison \& Lindell 2012), by planting fruit trees (Tscharntke et al., 2011) and further methods

\section{Kesimpulan dan Rekomendasi Manajemen}

\section{Burung dan kelelawar meningkatkan produksi kakao}

Penelitian kami menekankan pentingnya pengaruh ekonomi burung dan kelelawar yang menyediakan jasa ekosistem yang efektif seperti pengendalian serangga hama alami dalam sistem agroforestri kakao. Kehadiran burung dan kelelawar menyebabkan peningkatan hasil panen kakao minimal 31\% di daerah penelitian kami.

Dampak ekonomi yang kuat ini menunjukkan bahwa fungsi burung dan kelelawar sebagai pemangsa alami serangga hama harus dimasukkan dalam manajemen pertanian agroforestri kakao untuk menyediakan metode manajemen berkelanjutan yang memiliki efek positif pada ekonomi rakyat. Populasi burung dan kelelawar harus didukung dalam pertanian agroforestri kakao untuk mendukung fungsi ekologis mereka.

Hal tersebut dapat diwujudkan dengan cara meningkatkan jumlah spesies pohon naungan (Clough dkk., 2011; Tscharntke dkk., 2011), mengeskpos kotak-kotak sarang untuk burung dan kelelawar (Morrison \& Lindell, 2012), menanam pohon buah-buahan (Tscharntke $d k k$., 2011) dan 
that improve the availability of nesting sites and food resources for insectivorous birds and bats.

An increased appreciation of ecosystem services and natural resources will allow for an increased establishment of biodiversity-friendly methods in agroforestry systems which could in turn (due to a more sustainable use of resources) relieve the pressure from natural forest habitats and forest margin areas, which are very important for the functional diversity and also climatic conditions in our study area. metode-metode yang lebih lanjut meningkatkan ketersediaan sarang dan sumber makanan untuk burung dan kelelawar pemakan serangga.

Peningkatan apresiasi pada jasa ekosistem dan sumber daya alam akan memungkinkan adanya peningkatan penggunaan metode-metode yang ramah keragaman hayati dalam sistem pertanian agroforestri. Penggunaan metode tersebut kemudian (karena penggunaan sumber daya yang berkelanjutan) dapat meringankan tekanan untuk hutan primer dan kawasan batas hutan yang sangat penting untuk keragaman fungsional dan juga kondisi iklim di daerah penelitian kami.

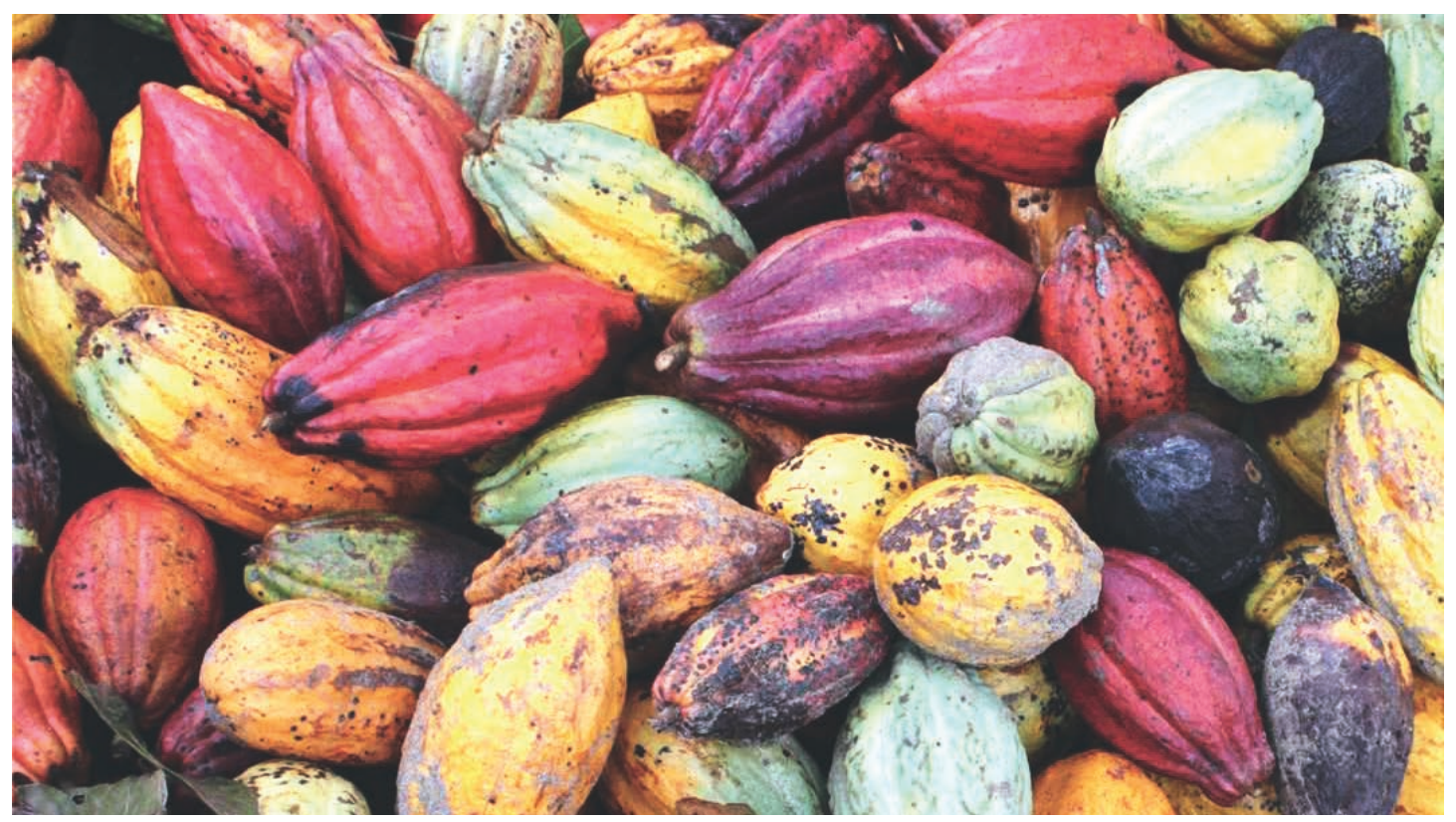

Fig. 15: Birds and bats save up to $31 \%$ of the cacao crop yields because they provide natural pest insect predation. This effect corresponds to 730 US-Dollar or 8.6 million Indonesian Rupiah (per one hectare and one year) that are saved due to the presence of birds and bats in cacao plantations. Photo credits: B. Maas.
Gbr. 15: Burung dan kelelawar menyelamatkan hingga $31 \%$ dari hasil panen kakao karena fungsinya sebagai pemangsa alami serangga hama. Efek ini sebanding dengan 8,6 juta Rupiah (per hektar per tahun) yang diselamatkan karena kehadiran burung dan kelelawar di perkebunan kakao. Foto: B. Maas. 


\section{Pest control in cacao - common species and forest proximity}

Our results from bird community investigations and predations experiments show that enhancing bird predation services can be of advantage both for human well-being (i.e. smallholder farmers) and biodiversity, thus representing a win-win situation for both sides. Our study shows the important function of the most common bird species within our study sites (Zosterops chloris; Indonesian: Kacamata Laut), which was dominating the predation on artificial caterpillars. Because this species is much more abundant in cacao agroforestry systems close to the forest margin, its predation service increases with increasing forest proximity. Secondly, higher densities of bird species also increase the effect of positive predation services.

Accordingly, it can be recommended to enhance the density of those insect eating bird species in the cacao plantations in Central Sulawesi, for example by providing attractive resources for these bird species (e.g. nesting resources and food resources). This can be done by planting trees which are both suitable to provide shade in the plantation as well as attractive nesting sites and perching spots for birds. In this context, all trees are suitable which grow higher than the cacao plantations and have a wide canopy. Fruiting trees are especially suitable because they can provide an additional income (e.g. Avocado; Orange; Durian; Candlenut; etc.).

\section{Pengendalian hama kakao - spesies yang sering ditemui dan jarak dengan hutan}

Hasil investigasi kami terhadap komunitas burung dan eksperimen predasi menunjukkan bahwa peningkatkan jasa predasi burung dapat memberikan manfaat baik untuk kesejahteraan manusia (yaitu petani kakao) dan keragaman hayati, sehingga menguntungkan untuk kedua belah pihak. Penelitian kami menunjukkan fungsi penting jenis burung yang paling umum di lokasi penelitian kami (Burung Kacamata Laut; nama ilmiah: Zosterops chloris) yang mendominasi predasi ulat palsu dalam eksperimen kami. Karena spesies ini jauh lebih banyak dalam sistem pertanian agroforestri kakao yang dekat dengan batas hutan, maka jasa predasi meningkat jika kebun semakin dekat dengan hutan. Kedua, kepadatan populasi spesies burung pemakan serangga juga dapat meningkatkan efek positif jasa predasi.

Dengan demikian, rekomendasi yang dapat diberikan adalah meningkatkan kepadatan spesies burung pemakan serangga di perkebunan kakao di Sulawesi Tengah, misalnya dengan menyediakan sumber daya yang menarik untuk jenis burung ini (misalnya sumber daya sarang dan sumber makanan). Hal ini dapat dilakukan dengan menanam pohon yang cocok untuk memberikan naungan di perkebunan, serta tempat yang menarik burung untuk bersarang dan bertengger. Dalam konteks ini, semua pohon cocok ditanam dalam kebun kakao jika tumbuh lebih tinggi dari pohon-pohon kakao dan memiliki kanopi lebar. Pohon buah adalah pilihan yang sangat cocok karena dapat memberikan penghasilan tambahan (misalnya pohon Alpukat, Jeruk, Durian, Kemiri, dll). 


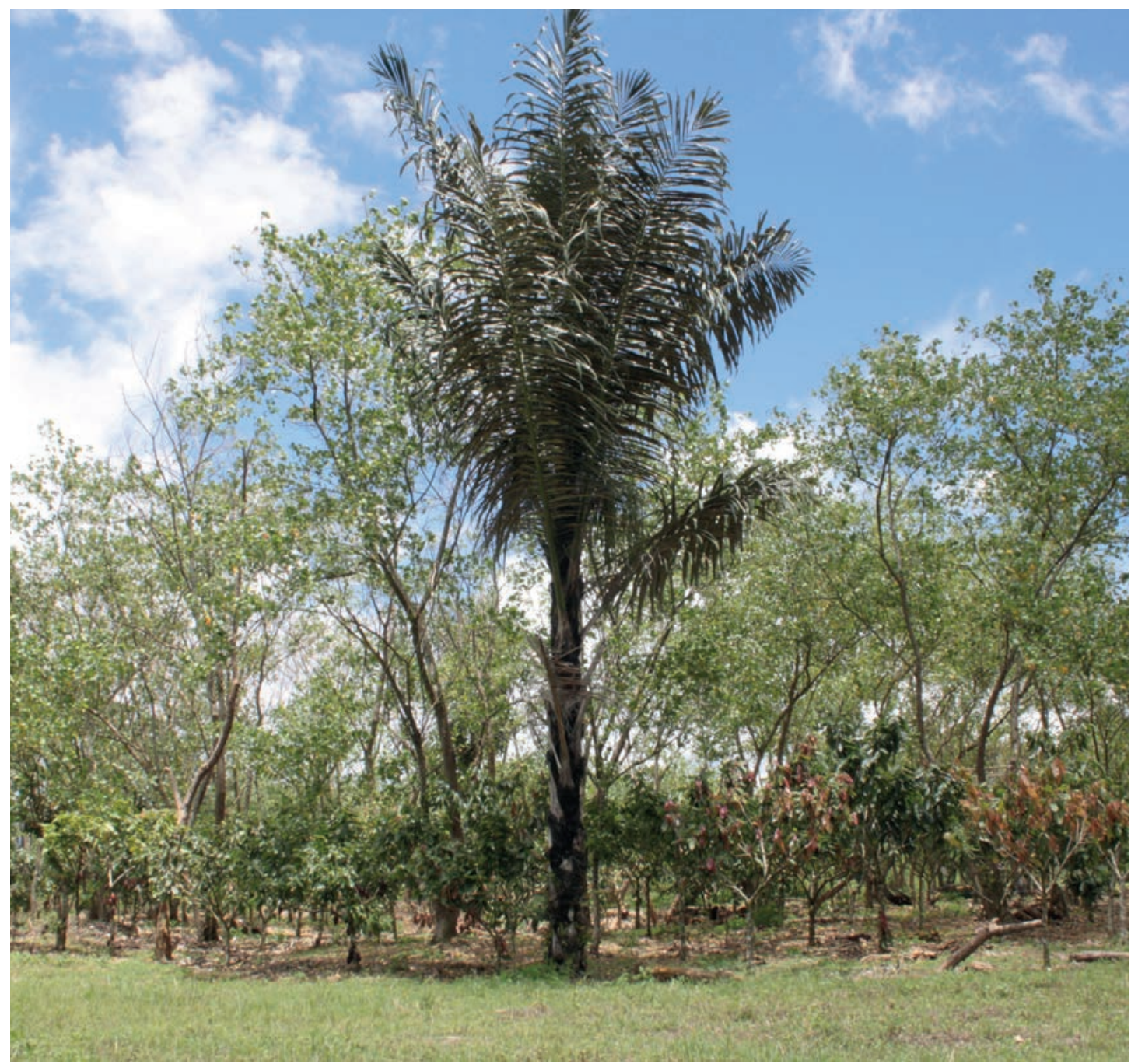

Fig. 16: Cacao plantations can be managed very differently. The potential of integrating natural ecosystem services (predation of pest insects by birds and bats) into this agroforestry system depends strongly on the management and the landscape structure (proximity to forest enhances services). Photo credits: B. Maas.
Gbr. 16: Perkebunan kakao dapat dikelola dengan cara yang sangat berbeda. Potensi integrasi jasa ekosistem alami (predasi burung dan kelelawar) ke dalam sistem pertanian agroforestri ini sangat bergantung pada manajemen dan struktur lanskap (kedekatan jarak ke hutan mendukung terciptanya jasa ekosistem).

Foto: B. Maas 
Policy-makers and land owners, especially agroforestry smallholders, should pay attention to the economic impact of the natural pest control that is provided by birds and bats and that affects crop productivity in a positive way (Karp et al., 2013; Maas et al., 2013; Maas et al., $2015 b$ ) and start to integrate ecosystem services in the management of agricultural landscapes in the tropics.

A global study of the ecosystem services provided by birds and bats showed that these two groups have a great potential to significantly contribute to biodiversity-friendly management of tropical farming landscapes (Maas et al., 2015b), with positive effects for conservation and human well-being through supporting food security and ecosystem resilience (Fischer et al., 2006; Tscharntke et al., 2012a).
Pembuat kebijakan dan pemilik lahan, terutama petani kecil agroforestri, harus memperhatikan dampak ekonomi pengendalian hama alami yang diberikan oleh burung dan kelelawar dan yang memiliki pengaruh positif pada produktivitas tanaman (Karp dkk., 2013;. Maas $d k k$., 2013) dan mulai mengintegrasikan jasa ekosistem dalam manajemen daerah pertanian di daerah tropis.

Studi global jasa ekosistem yang disediakan oleh burung dan kelelawar menunjukkan bahwa dua kelompok tersebut memiliki potensi besar untuk berkontribusi secara signifikan pada manajemen lanskap pertanian tropis yang ramah keragaman hayati (Maas $d k k$., 2015b), dengan efek positif untuk konservasi dan kesejahteraan manusia melalui dukungan terhadap ketahanan pangan dan resiliensi ekosistem (Fischer $d k k$., 2006;. Tscharntke $d k k, 2012 \mathrm{a}$ ). 



\section{9}

\section{Relevance of \\ the Research}

Relevansi

Penelitian Kami
$\mathrm{I}$

ndonesia is the largest producer of cacao in South-East Asia and the third largest producer worldwide (Moser et al., 2010). The country has 1.5 million hectares of cacao plantations, mostly in the eastern Sulawesi island, with an extra 10,000 to 20,000 hectares of additional production due the last years (Wall Street Journal, 2011). Contrasting to its economic importance, the island of Sulawesi is the largest within the Indonesian biodiversity hotspot Wallacea with an outstanding amount of endemic birds (Stattersfield et al., 1998) and a very high proportion of endemic species from various other taxa (e.g. Lee et al., 2007). Around $30 \%$ of the birds in Sulawesi are endemic which means that they only occur on Sulawesi and its satellite island, but nowhere else on the planet.

The need of the explosively growing human population (Keinan and Clark 2012) for food, fuel and fibre, biological products and many other ecosystem processes and services ( $M A$ 2005) leads to an ongoing transformation of natural tropical landscapes, mainly into agricultural land (Archard 2002).
๘ ndonesia adalah produsen terbesar kakao di Asia Tenggara dan terbesar ketiga di dunia (Moser dkk., 2010). Indonesia memiliki 1,5 juta hektar perkebunan kakao, sebagian besar terletak di pulau Sulawesi bagian timur, dengan tambahan produksi 10.000 hingga 20.000 hektar selama beberapa tahun terakhir (Wall Street Journal, 2011).

Bertolak belakang dengan nilai penting ekonominya, Pulau Sulawesi merupakan hotspot keragaman hayati Wallacea terbesar di Indonesia dengan jumlah burung endemik yang luar biasa banyak (Stattersfield $d k k$., 1998) dan proporsi spesies endemik dari berbagai taksa lainnya yang sangat tinggi (Lee $d k k$., 2007). Sekitar 30\% burung di Sulawesi adalah endemik, yang berarti bahwa mereka hanya ada di Sulawesi dan pulau sekitarnya, tapi tidak ada di tempat lain di dunia ini.

Meledaknya jumlah populasi manusia (Keinan dan Clark, 2012) meningkatkan kebutuhan akan makanan, bahan bakar dan serat, produk-produk biologis dan banyak proses dan jasa ekosistem lainnya (MA, 2005). Hal ini menyebabkan perubahan lanskap alami tropis, terutama menjadi lahan pertanian (Archard, 2002). 


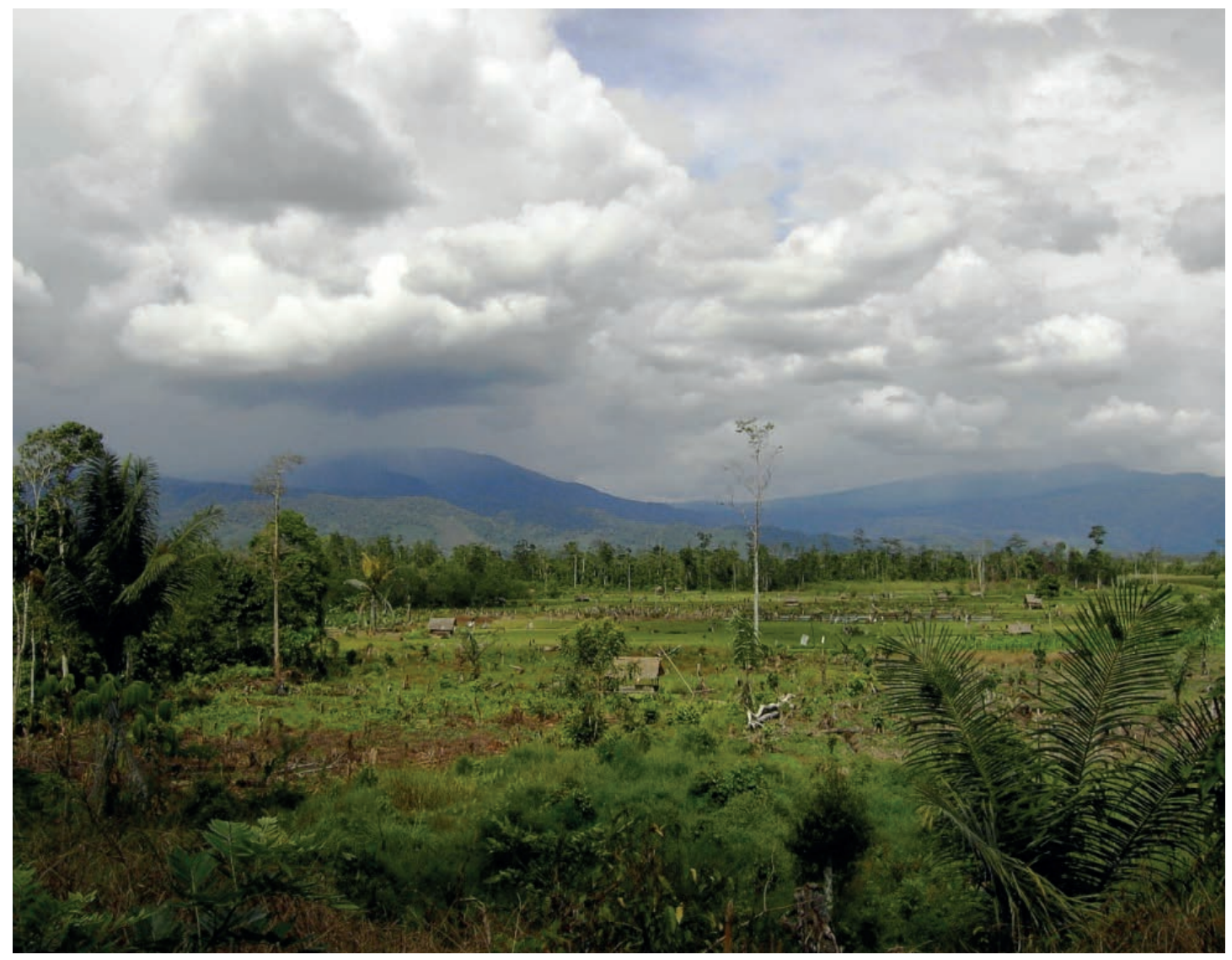

Fig. 17: Napu is a highly dynamic land use area but the potential to integrate ecosystem services into agroforestry management of cacao is high, as well as to use other benefits of the high biodiversity in a sustainable way (e.g. supporting ecotourism). The value of biodiversity and functional diversity is very high, also in land use systems.

Photo credits: B. Maas.

Gbr. 17: Napu adalah area yang penggunaan lahannya sangat dinamis namun memiliki potensi tinggi untuk mengintegrasikan jasa ekosistem dalam manajemen pertanian agroforestri kakao, serta untuk menggunakan manfaat lain dari keragaman hayati yang tinggi secara berkelanjutan (misalnya wisata lingkungan). Keragaman hayati dan keragaman fungsinya memiliki nilai sangat tinggi, termasuk untuk sistem penggunaan lahan. Foto: B. Maas. 
Deforestation and conversion of tropical forests as well as land use intensification drive the loss of biodiversity and many associated ecosystem services in the tropics (e.g. Lawton et al., 1998; Daily 2001). In this context, the combination of effective agricultural land use with biodiversity conservation represents a challenge that is of upmost priority.

In conclusion, agroforestry practices which facilitate win-win situations for both human well-being and biodiversity in the tropics, represent a great chance for more sustainable development of human actions in the future.
Deforestasi dan konversi hutan tropis serta intensifikasi penggunaan lahan mendorong berkurangnya keragaman hayati dan jasa ekosistem terkait di daerah tropis (Lawton $d k k ., 1998$;. Daily, 2001). Dalam konteks ini, kombinasi penggunaan lahan pertanian yang efektif dengan konservasi keragaman hayati merupakan tantangan yang perlu diprioritaskan.

Kesimpulannya, praktik pertanian sistem agroforestri yang memfasilitasi keuntungan bagi kesejahteraan manusia dan keragaman hayati, menggambarkan kesempatan yang baik untuk terus meningkatkan peran manusia dalam pembangunan yang berkelanjutan. 



\section{Cacao Farmer}

Workshops and

Discussion of Results uring her research activities in Central Sulawesi, Dr. Bea Maas arranged monthly presentations for the local cacao farmer community in her study area. Together with scientists and students from the University of Göttingen and the University of Tadulako, research results were discussed and the feedback of farmers was taken into account in further research activities.

The farmer workshops were continued after the analyses and publication of research results. In June and July 2014, Bea Maas and the Tadulako University organized a presentation series to communicate her final results and the current state of knowledge concerning ecosystem service management of birds and bats in cacao agroforestry, including two public workshops for farmers and land use managers in Central Sulawesi and several presentations at Indonesian Universities and research institutes.

As part of the farmer workshops in her former study sites, first versions of this guide were distributed to farmers and the research results were discussed in detail. This meeting was

\section{Lokakarya Petani Kakao dan Diskusi Hasil Penelitian}

0 elama kegiatan penelitiannya di Sulawesi Tengah, Dr. Bea Maas mengadakan presentasi bulanan untuk masyarakat petani kakao lokal di daerah penelitiannya. Bersama para ilmuwan dan juga mahasiswa dari Universitas Göttingen dan Universitas Tadulako, hasil penelitian dibahas untuk memperoleh umpan balik dari petani yang menjadi pertimbangan dalam kegiatan penelitian selanjutnya.

Lokakarya petani dilanjutkan setelah analisis dan publikasi hasil penelitian. Pada bulan Juni dan Juli 2014, Bea Maas dengan Universitas Tadulako menyelenggarakan serangkaian presentasi untuk menyampaikan hasil akhir dan temuan terbaru tentang manajemen jasa ekosistem burung dan kelelawar di agroforestri kakao, termasuk dua lokakarya terbuka untuk petani dan pengelola lahan di Sulawesi Tengah dan beberapa presentasi di berbagai universitas dan lembaga penelitian di Indonesia.

Sebagai bagian dari lokakarya petani di lokasi penelitiannya, versi pertama dari panduan ini dibagikan kepada petani dan hasil penelitian dibahas secara rinci. Pertemuan tersebut 


\section{The feedback of the local farmer community also showed, that there is a common concern regarding the negative impact of agricultural chemicals (such as pesticides, herbicides, fungicides) and the design of future cacao management.}

supported by Mr. Djoni Pogoa (Village Head of Wuasa) and Ilfianti Kasmudin (Tadulako University-interpreter). Dr. Bea Maas answered questions about the importance of birds, bats and ecosystem services provided in cacao agroforestry systems. Another important part of the open discussion focused on shade tree management and how local management can enhance the positive effects of ecosystem services. Finally, she answered questions about the management of the different cacao diseases.

With emphasizes on the positive effects of birds, bats and natural predators of pest insects (e.g. ants and spiders) in cacao plantations, important strategies and approaches of cacao cultivation were discussed. In addition, the effects of intensive management (e.g., no shade trees and with pesticides) were described and how alternative management strategies can contribute to a more sustainable use and management of resources and cacao farms (e.g., shade tree management, regional management and conservation of forests). The feedback of the didukung oleh Bapak Djoni Pogoa (Kepala Desa Wuasa) dan Ilfianti Kasmudin (Universitas Tadulako - penterjemah). Dr. Bea Maas menjawab pertanyaan-pertanyaan tentang pentingnya burung, kelelawar dan jasa ekosistem yang disediakan dalam sistem agroforestri kakao. Bagian penting lainnya dari diskusi terbuka tersebut berfokus pada manajemen pohon naungan dan bagaimana manajemen lokal dapat meningkatkan efek positif dari jasa ekosistem. Di akhir pertemuan, ia menjawab pertanyaanpertanyaan tentang manajemen berbagai penyakit kakao.

Dengan penekanan pada efek positif burung, kelelawar dan predator alami hama serangga (misalnya semut dan laba-laba) di perkebunan kakao, strategi dan pendekatan budidaya kakao yang penting juga didiskusikan. Selain itu, efek manajemen perkebunan secara intensif (misalnya, tidak ada pohon naungan dan menggunakan pestisida) juga dijelaskan dan kemudian disampaikanlah bagaimana strategi manajemen alternatif dapat berkontribusi untuk penggunaan yang lebih berkelanjutan dan manajemen sumber daya dan perkebunan kakao (misalnya, manajemen 


\section{Umpan balik dari masyarakat petani lokal menunjukkan bahwa ada kekhawatiran bersama tentang dampak negatif bahan kimia pertanian (pestisida, herbisida, fungisida) dan desain manajemen kakao masa depan.}

local farmer community also showed, that there is a common concern regarding the negative impact of agricultural chemicals (such as pesticides, herbicides, fungicides) and the design of future cacao management. To provide knowledge and better research results concerning the questions cacao farmers in Napu, there is a need for further research on the effects of pesticides on cacao plantations in Central Sulawesi, also to provide knowledge that contributes to the reduction of the need for pesticides.

In general, the response of all cacao farmers was very positive. They followed the presentations with great interest and contributed to the open discussion. Both the presentation material and a report of discussions are provided in the following chapter. The protocol of our discussions reflects the main interest and concerns of smallholder cacao farmers and therefore provides important information for scientists who plan studies in smallholder farming landscapes. pohon naungan, manajemen regional dan juga konservasi hutan). Umpan balik dari masyarakat petani lokal menunjukkan bahwa ada kekhawatiran bersama tentang dampak negatif bahan kimia pertanian (pestisida, herbisida, fungisida) dan desain manajemen kakao masa depan. Untuk memberikan pengetahuan dan hasil penelitian yang lebih baik tentang pertanyaan petani kakao di Napu, terdapat kebutuhan untuk penelitian lebih lanjut tentang efek pestisida pada perkebunan kakao di Sulawesi Tengah, juga untuk memberi pengetahuan yang dapat berkontribusi untuk pengurangan kebutuhan pestisida.

Secara umum, tanggapan semua petani kakao sangat positif. Mereka mengikuti presentasi dengan antusias dan berkontribusi saat diskusi terbuka. Materi presentasi dan laporan diskusi disajikan pada bab selanjutnya. Protokol diskusi tersebut mencerminkan kepentingan dan kekhawatiran utama petani kecil kakao dan dengan demikian dapat menyediakan informasi penting untuk para ilmuwan yang berencana meneliti lanskap kebun rakyat. 



\section{Open Discussions and Response From Cacao Farmers}

$\mathrm{H}$ ere, we provide a report of the open discussion with cacao farmers in Central Sulawesi, resulting from two final workshops held in June and July 2014. The workshop was facilitated and coordinated by Tadulako University with the village head. Ilfianti Kasmudin from CTFM (Centre for Forest Margin Research) of Tadulako University asked by Dr. Aiyen Tjoa from Agriculture Faculty of Tadulako University to help in field as interpreter. She also wrote the protocol during these events, including all questions from cacao farmers and stakeholders (indicated by "Q1", “Q2", "Q3", ...) and the responses of Dr. Bea Maas (indicated by "R1", "R2”, “R3”, .).

\section{Q1: Questions regarding the impact of} pesticides on birds and bats: What is the effect of pesticides on birds and bats and ecosystem services they provide (e.g., eating pest insects)?

R1: We do not have data on the impact of pesticides directly on the number of species of birds and bats in cacao or positive about the services they provide. During our research, cacao farmers did not use pesticides on the trees

\section{Diskusi Terbuka dan Tanggapan dari Petani Kakao}

$\mathrm{D}$ i sini kami melaporkan hasil diskusi terbuka dengan para petani kakao di Sulawesi Tengah yang dihasilkan dari dua lokakarya yang diadakan pada bulan Juni dan Juli 2014. Pertemuan ini difasilitasi Universitas Tadulako dan dikoordinasikan dengan kepala desa. Ilfianti Kasmudin dari pusat studi Forest Margin diminta Dr. Aiyen Tjoa dosen Fakultas Pertanian Universitas Tadulako membantu sebagai penterjemah dan pencatat protokol pada saat berlangsungnya lokakarya . Termasuk mencatat semua pertanyaan dari petani kakao dan pemangku kepentingan (diberi tanda “T1”, “T2”, “T3”, ...) dan tanggapan dari Dr. Bea Maas (Ditunjukkan dengan “J1", “J2”, “J3”, ...).

T1: Pertanyaan mengenai dampak pestisida pada burung dan kelelawar: Apa efek pestisida pada burung dan kelelawar dan jasa ekosistem yang mereka sediakan (misalnya memakan serangga hama)?

J1: Kami tidak memiliki data tentang dampak pestisida secara langsung pada jumlah spesies burung dan kelelawar di perkebunan kakao atau jasa positif yang mereka berikan. Selama penelitian kami, petani kakao tidak menggunakan pestisida 
of our study because this would change the population of insects and spiders, which we studied for several months (because we wanted to study the effect on birds and bats prey on insect populations. The use of pesticides would have influenced and therefore changed our results). Therefore, it is difficult to give an answer from the direct impact of pesticides on birds and bats. But we know that pesticides can increase the stress of cacao trees and negatively affect the soil quality in land use systems. We expect an indirect negative effect of pesticides on birds and bats, because the use of pesticides reduces natural resources that are used by them (if birds and bats cannot find food or nesting sites in cacao plantations, it is likely that they will avoid these plantations).

\section{Q2: Questions about our experiment and the} results on the insect population in cacao: Do you find an insect is more active during the day or night? Which groups are more active? Are birds or bats more important for the provision of ecosystem services of cacao? Did the fishing nets used for experiments affect these insects?

R2: Our answer was supported by results from our research, which are presented above (Table 1 ), showing the differences of insect abundances during day and night and in different parts of the cacao trees (branches, fruits, flowers, leaves). Secondly, we presented the detailed results showing cacao reduction due to the absence of birds and bats (see our presentation), showed differences in support for cacao by birds ( 9\%) and bats $(\sim 22 \%)$. di pohon-pohon yang kami teliti karena ini akan mengubah populasi serangga dan laba-laba, yang kami teliti selama beberapa bulan (karena kami ingin mengetahui efek dari predasi burung dan kelelawar pada populasi serangga. Penggunaan pestisida akan mempengaruhi dan kemudian mengubah hasil penelitian kami). Karena itu, sulit untuk memberikan jawaban mengenai dampak langsung pestisida pada burung dan kelelawar. Meskipun demikian kita tahu bahwa pestisida dapat meningkatkan stres pada pohon kakao dan berpengaruh negatif pada tanah di kebun kakao. Kami memperkirakan ada efek negatif tidak langsung dari pestisida pada burung dan kelelawar, karena penggunaan pestisida mengurangi sumber daya alam yang digunakan oleh burung dan kelelawar (jika burung dan kelelawar tidak dapat menemukan makanan atau tempat bersarang di kebun kakao, mereka tidak akan tertarik untuk aktif di kebun kakao tersebut).

\section{T2: Pertanyaan mengenai eksperimen kami} dan hasilnya pada populasi serangga di kakao: Apakah Anda menemukan serangga lebih aktif di siang hari atau malam hari? Kelompok mana yang lebih aktif? Apakah burung atau kelelawar yang lebih penting untuk penyediaan jasa ekosistem di kebun kakao? Apakah jaring nelayan yang digunakan untuk eksperimen mempengaruhi serangga ini?

J2: Jawaban kami didukung oleh hasil penelitian yang dapat dilihat di Tabel 1 . Hasil penelitian kami menunjukkan perbedaan kelimpahan serangga selama siang dan malam pada bagian-bagian pohon yang berbeda (cabang, buah-buahan, bunga, daun). Kedua, kami sudah menampilkan hasil rinci yang menunjukkan pengurangan hasil produksi kakao karena tidak adanya burung dan kelelawar (lihat presentasi kami), dan menunjukkan perbedaan 
Finally we explained, that the size of the used fished nets used for our experiments allowed access of large insects (e.g., large beetles, dragonflies) but did not allow access by birds or bats when the experimental cage was closed.

The activities of different insect groups depends on the activity and traits of the different species. In general we can say that the ecosystem services provided during the night (bats) are very important in the system cacao. Bats reduce the number of many types of insects are nocturnal and are capable of affecting the productivity of cacao. The most common species of pest insects, ants and spiders are presented in Table 1 as well as in Fig. 8 and Fig. 9. Especially aphids showed a strong interaction with birds and bats and the cacao yield in all investigated farms, serving as one good example for the positive impact of birds and bats on pest reduction and crop yield.

Q3: Questions about the management of shade tree in cacao: does shade tree management result in better yield quality or quantity? What is the optimal amount of shade trees for cacao management?

R3: We presented the results of previous studies made on cacao plantations in Central Sulawesi (e.g., Clough et al., 2011) which showed that a combination of high yield and high biodiversity (the number of species in cacao, including tree species and species of animals) in agricultural dukungan untuk hasil panen kakao oleh burung ( 9\%) dan kelelawar ( 22\% ).

Terakhir, kami menjelaskan bahwa ukuran lubang jaring yang digunakan dalam eksperimen kami memungkinkan akses serangga besar (misalnya kumbang besar, capung) tetapi tidak memberikan akses untuk burung atau kelelawar saat sungkup eksperimen ditutup.

Kegiatan kelompok serangga yang berbeda bergantung pada kegiatan dan sifat spesies yang berbeda. Secara umum kami dapat mengatakan bahwa jasa ekosistem yang diberikan selama malam hari (oleh kelelawar) sangat penting dalam sistem perkebunan kakao. Kelelawar dapat mengurangi jumlah banyak jenis serangga yang aktif di malam hari dan yang mampu mempengaruhi produktivitas kakao. Spesies serangga hama, semut, dan laba-laba yang paling banyak ditemukan dapat dilihat di Tabel 1, Gbr. 8, dan Gbr. 9. Kutu adalah jenis yang paling menunjukkan interaksi kuat dengan burung dan kelelawar dan hasil panen kakao di semua kebun yang diteliti. Hal tersebut menjadi contoh yang baik mengenai dampak positif burung dan kelelawar terhadap pengurangan hama dan hasil produksi tanaman.

T3: Pertanyaan tentang manajemen pohon naungan di kebun kakao: manajemen pohon naungan meningkatkan kuantitas atau kualitas hasil produksi? Berapa jumlah pohon naungan yang optimal untuk manajemen kakao?

J3: Kami mempresentasikan hasil dari studi sebelumnya yang dilakukan di kebun-kebun kakao di Sulawesi Tengah (misalnya Clough $d k k$., 2011) yang menunjukkan bahwa kombinasi hasil yang tinggi dan keragaman hayati yang tinggi (jumlah spesies lain di dalam kebun kakao, termasuk 


\section{We stressed the importance of}

birds and bats reducing the

numbers of cacao damaging crop

pests. Furthermore, we explained

that the birds' ecosystem services

are positively correlated with

the proximity of the forest and

that they are driven by the most

common species in the cacao

gardens of our study area:

The Lemon-bellied White-eye

(Zosterops chloris).

systems in tropical countries is possible. We explained that the shade cover $30 \%$ to $40 \%$ is optimal to achieve high cacao yield but also benefit from the services of natural ecosystems to birds and bats (because they are attracted by the resources provided by shade trees, such as nesting site). This result is also shown in Fig. 13, which refers to a number of relevant studies on the importance of shade tree management in cacao farms. We discussed the risk of intensive application of agrochemical (such as pesticides and other chemicals) and we explained the advantages of more extensive or sustainable land-use management (e.g., higher ecosystem resilience, ecosystem services are more available; lower risk of contamination of soil and water land;
Kami menekankan pentingnya burung dan kelelawar dalam menekan jumlah hama yang merusak tanaman kakao. Selanjutnya, kami menjelaskan bahwa jasa ekosistem burung berkorelasi positif dengan kedekatan jarak kebun ke hutan dan jasa tersebut dikendalikan oleh spesies yang paling umum dikebun-kebun kakao di Napu: Kacamata Laut (Zosterops chloris).

spesies pohon dan spesies binatang) dalam sistem pertanian di negara tropis adalah hal yang sangat mungkin. Kami menjelaskan bahwa naungan $30 \%$ sampai $40 \%$ optimal untuk mencapai hasil kakao tinggi tetapi juga mendapat keuntungan dari jasa ekosistem alami dengan burung dan kelelawar (karena mereka tertarik dengan sumber daya yang disediakan oleh pohon naungan, misalnya tempat bersarang). Hasil ini juga kami tampilkan di Gbr. 13, yang merujuk pada penelitianpenelitian yang relevan mengenai pentingnya manajemen pohon naungan di kebun kakao. Kami mendiskusikan risiko penggunaan bahan kimia yang intensif (misalnya pestisida dan kimia lain) dan kami menjelaskan keuntungan dari manajemen penggunaan lahan yang lebih ekstensif atau 
sustainability is higher). Finally, we explained how the cutting of shade trees can increase the stress on the cacao tree, which may affect the sustainability of cacao production, for example in times of severe droughts.

\section{Q4: Question on the effects of agricultural} chemicals: What's worse: herbicides or pesticides?

R4: Our research did not investigate the negative effects of agricultural chemicals. We reported results from an earlier study (Clough et al., 2011, PNAS), showing that cacao is positively correlated with the number of hours worked in the garden and use of pesticides, but there is no positive correlation with fertilization. The multifunctional role of shade trees is still poorly understood (Tscharntke et al., 2011). Shade trees can be used in various ways: they can increase diversity in cacao plantations and hence it can increase the number of positive ecosystem services in cacao. In addition, shade trees that provide fruits (e.g., Avocado trees, Tamarind, Durian) can provide additional crop for farmers and therefore an extra income.

Number of herbaceous plants in cacao negatively correlated with the cacao harvest. Nevertheless, these results should be interpreted with caution. Although the use of pesticides and crop cacao showed a positive correlation, the use of pesticides does not reduce the major cacao pests (e.g., black fruit diseases and insect pests Conopomorpha cramerella) in our study. Long-term negative effects of pesticides and herbicides (such as the berkelanjutan (misalnya resiliensi ekosistem yang lebih tinggi, jasa ekosistem yang lebih banyak tersedia; risiko kontaminasi tanah dan air tanah yang lebih rendah; keberlanjutan yang lebih tinggi). Akhirnya, kami menjelaskan bagaimana pemotongan pohon naungan dapat meningkatkan stres pada pohon kakao, yang mungkin dapat mempengaruhi keberlanjutan produksi kakao misalnya di musim kemarau yang parah.

\section{T4: Pertanyaan tentang efek dari bahan kimia} pertanian: Apa yang lebih buruk: Herbisida atau pestisida?

J4: Kami tidak melakukan penelitian tentang efek negatif bahan kimia pertanian. Kami melaporkan hasil penelitian sebelumnya (Clough $d k k$., 2011, PNAS) bahwa hasil produksi kakao berkorelasi positif dengan jumlah jam kerja di kebun dan pengunaan pestisida, tetapi tidak ada korelasi yang positif dengan pemupukan. Peran multifungsi pohon naungan masih kurang dipahami (Tscharntke $d k k$., 2011). Pohon naungan dapat digunakan untuk berbagai kegunaan: mereka dapat meningkatkan keragaman dalam kebun kakao dan karena itu dapat meningkatkan jumlah jasa ekosistem positif di kebun kakao. Selain itu, pohon naungan yang berbuah (misalnya pohon Alpukat, Kemiri, Durian) dapat memberikan tambahan hasil panen bagi petani dan dengan demikian meningkatkan penghasilan tambahan.

Jumlah tumbuhan herbal di kebun kakao berkorelasi negatif dengan hasil panen kakao. Namun demikian, hasil ini harus ditafsirkan dengan hati-hati. Meskipun penggunaan pestisida dan hasil tanaman kakao menunjukkan korelasi positif, penggunaan pestisida tidak mengurangi hama kakao yang utama (misalnya penyakit busuk buah dan serangga hama Conopomorpha cramerella) dalam penelitian kami. Efek jangka panjang 
effects on ground water and soil quality) should also be considered (but we did not study agricultural chemicals in our study area).

\section{Q5: The question of cacao pests: Which cacao} pest is the worst? How can we manage the functions provided by birds and bats? How to manage black pod disease?

R5: To answer this question, we provided information about the major cacao pests and natural fruit abortion (a natural reaction of cacao trees that is often confused with cacao diseases; see our presentation material). We mention the results of Dr. Clough et al. (2011), who identified the Black Pod Disease (Phytophtora palmivora; a fungi species) as the most serious pests of cacao in their research areas around the Lore Lindu National Park. We mentioned that we did not find a significant effect of birds and bats on cacao diseases or damage of cacao leaves. In this context, we explain the ambivalent role of ants in cacao (based on the results according to Dr. Wielgoss et al.) which can provide positive effects along the negative effects on cacao (positive effect is the reduction of insect pests such as larvae. The negative effect is the pest insect protection such as mealybugs and crickets), but the positive effect of ants on cacao yield is prevailing.

Black cacao pods can be affected by different diseases (in our area, especially Phytophtora palmivora) or the natural reaction of the cacao tree itself (known as the "Cherelle Wilt"). However, we often observe that affected cacao fruits are pestisida dan herbisida (misalnya efek pada air tanah dan pada kualitas tanah) juga harus dipertimbangkan, meskipun kami tidak meneliti bahan kimia pertanian di daerah penelitian kami.

\section{T5: Pertanyaan tentang hama kakao: Hama} kakao mana yang terburuk? Bagaimana kita bisa mengelola fungsi yang disediakan oleh burung dan kelelawar? Bagaimana mengelola penyakit busuk buah?

J5: Untuk menjawab pertanyaan ini, kami menyediakan beberapa informasi tentang hama kakao utama dan aborsi buah alami (reaksi alami pohon kakao yang sering tertukar dengan penyakit kakao, lihat presentasi kami). Kami menyebutkan hasil penelitian dari Dr Clough dkk., (2011), yang mengidentifikasi Penyakit Busuk Buah (Phytophtora palmivora — jenis jamur) sebagai hama kakao yang paling serius di daerah penelitian mereka di sekitar Taman Nasional Lore Lindu. Kami menyebutkan bahwa kami tidak menemukan efek yang signifikan dari burung dan kelelawar pada penyakit kakao atau kerusakan daun. Dalam konteks ini, kami menjelaskan peran yang ambivalen dari semut dalam kebun-kebun kakao (berdasarkan hasil menurut Dr. Wielgoss $d k k$.) ) yang dapat memberikan efek positif bersama efek negatif di kebun kakao (efek positifnya adalah pengurangan serangga hama seperti larva dan efek negatifnya adalah perlindungan serangga hama lain seperti kutu daun dan jangkrik) namun efek positif semut pada pohon kakao tetap ada.

Buah yang hitam dapat dipengaruhi oleh penyakit yang berbeda (di daerah kami terutama Phytophtora palmivora) atau reaksi alami dari pohon kakao sendiri (dikenal dengan nama "Cherelle Wilt"). Bagaimanapun, kami sering 
dumped beside or close to the cacao trees in many farms. A simple management recommendation is to take affected fruits away from the plantation trees and burn them (since many diseases can be transferred through wind).

\section{Q6: Question on cacao pests: What happens} to cacao trees affected by "Branch Cancer" and "Fruit Cancer"? How is it managed?

R6: This disease occurs quite often in different plantations in Napu. We explained that the disease is caused by a fungi species known as Phytophtora palmivora. We saw that this disease mainly occurs in cacao plantations where the soils are too wet, although this is just an observation and not a result of our research. We assume that the wet soils may not be optimal for cacao agroforestry systems. Stem cancer disease is one of the important diseases for cacao plants caused by fungus infection Phytophtora palmivora on the trunk and branches of cacao plants. The cacao pest Phytophtora palmivora also causes rotten fruit and is often a result of previous infections by pest insects such as Helopeltis sulawesi (a mirid bug and major pest in cacao farms).

\section{Q7: Questions about the kinds of cacao seedlings: Can you recommend a variety of cacao seedlings for farmers in Napu?}

R7: We do not have information about the advantages and disadvantages of different cacao seedlings because the productivity of various different types of seeds that are also highly dependent on the local management in mengamati di banyak kebun bahwa buah-buah kakao yang sakit hanya dibuang di sebelah atau dekat dengan pohon-pohon kakao yang lain. Sebuah rekomendasi manajemen sederhana adalah membuang buah-buah kakao yang sakit jauh dari pohon-pohon di perkebunan dan membakarnya (karena banyak penyakit dapat tersebar melalui angin).

T6: Pertanyaan tentang hama kakao: Apa penyebab "Kanker Cabang” dan "Kanker Buah"? Bagaimana penyakit ini dikelola?

J6: Penyakit ini bisa cukup sering dijumpai di perkebunan-perkebunan di Napu. Kami menjelaskan bahwa penyakit ini disebabkan oleh jamur yang dikenal dengan nama Phytophtora palmivora. Kami melihat bahwa penyakit ini terutama terjadi di perkebunan kakao dengan tanah yang sangat basah, meskipun ini hanya sebuah pengamatan dan bukan hasil penelitian. Kami berasumsi bahwa tanah basah mungkin tidak optimal untuk sistem agroforestri kakao. Penyakit kanker batang adalah salah satu penyakit penting untuk tanaman kakao yang disebabkan oleh infeksi jamur Phythotora palmivora pada batang dan cabang tanaman kakao. Hama Phytoptora palmivora juga menyebabkan kebusukan buah dan seringkali terjadi setelah infeksi serangga seperti Helopeltis sulawesi.

T7: Pertanyaan mengenai jenis-jenis bibit kakao: Dapatkah Anda merekomendasikan suatu varietas bibit kakao untuk petani kakao di Napu?

J7: Kami tidak memiliki informasi tentang keuntungan dan kerugian dari bibit kakao yang berbeda karena produktivitas dari jenis bibit yang berbeda juga sangat tergantung pada manajemen lokal di perkebunan kakao 
the cacao plantations and farmers' knowledge. For example, the types of different cacao can be combined ("grafting"), which makes recommendations even more difficult. Finally, cacao seed selection also depends on the needs of consumers, because of the different types of cacao can create a different taste. Therefore, recommendations for a variety of specific cacao is very difficult.

\section{Q8: What are the effects on the mice and} squirrels cacao? In our farm it is a big problem.

R8: In our study, we noted the negative effects by rodents (e.g. rats and squirrels), but did not find a significant effect in the absence of birds and bats.

\section{Q9: Question regarding the species of birds} and bats that contribute positively to the cacao: Type of birds and bats that must be maintained to enhance the ecosystem services on cacao plantations?

R9: This questions was answered using presentation material (see Fig. 11 and Fig. 12) and we stressed the importance of birds and bats that reduce the number of cacao damaging crop pests. Furthermore, we explained that the birds' ecosystem services are positively correlated with the proximity of the forest and that they are driven by the most common species in the gardens of cacao in Napu: The Lemon-bellied White-eye (Zosterops chloris). We recommended to increase the resources for birds and bats that eat insects (e.g., installation of nesting boxes or providing natural nesting sites by planting different tree species) to enhance the positive effects of their ecosystem services. dan pengetahuan petani. Misalnya, jenis-jenis kakao yang berbeda dapat dikombinasikan ("tempel buah" dan "sambung samping"), yang membuat rekomendasi bahkan lebih sulit. Terakhir, pemilihan bibit kakao juga bergantung pada kebutuhan konsumen, karena jenis kakao yang berbeda bisa menciptakan cita rasa yang berbeda. Oleh karena itu, memberi rekomendasi varietas kakao tertentu sangat sulit.

T8: Apa efek tikus dan tupai pada buah kakao? Dalam perkebunan kami itu adalah masalah besar.

J8: Dalam penelitian kami, kami mencatat efek negatif hewan pengerat (misalnya tikus dan tupai) tetapi tidak menemukan efek yang signifikan saat tidak adanya burung dan kelelawar.

\section{T9: Pertanyaan tentang jenis burung dan} kelelawar yang berkontribusi positif terhadap kakao: Apa jenis burung dan kelelawar yang harus kita pelihara untuk meningkatkan jasa ekosistem di perkebunan kakao?

J9: Kami menjawab pertanyaan ini didukung oleh presentasi kami (lihat Gbr. 11 dan Gbr. 12) dan menekankan pentingnya burung dan kelelawar yang mengurangi jumlah hama yang merusak tanaman kakao. Selanjutnya, kami menjelaskan bahwa jasa ekosistem burung berkorelasi positif dengan kedekatan dengan hutan dan bahwa jasa tersebut didorong oleh spesies yang paling umum di kebun-kebun kakao di Napu: Kacamata Laut (Zosterops chloris). Selain itu, kami merekomendasikan untuk meningkatkan sumber daya untuk burung dan kelelawar pemakan serangga (misalnya menyediakan tempat bersarang) untuk meningkatkan efek positif dari jasa ekosistem mereka. 


\section{In times of rapid human}

population growth worldwide,

it is important to find

possibilities of a sustainable

cacao management that allows

the combination of human

welfare and the conservation

of biodiversity and natural

\section{resources.}

Q10: Question on the role of different shade tree species : Which shade tree species can be recommended?

R10: This is a very interesting question for future research. We could not find a correlation in our study that shows the effects of different types of shade trees on the number of different insect pests. Nevertheless, it would be interesting to investigate the influence of different types of shade trees on adjacent insect populations in further detail. In addition to these questions, we explained the different functions provided by the trees of the forest or fruit tree species (e.g., effects on local climate, carbon sequestration, additional income by selling fruits, nitrogen fertilization by legume trees) and how these trees can be associated with native forest biodiversity
Pada masa pertumbuhan

populasi manusia yang

sangat pesat di dunia ini,

penting untuk menemukan

kemungkinan manajemen

kakao berkelanjutan yang

memungkinkan mengkombinasi

kesejahteraan manusia dan

konservasi keragaman hayati

dan sumber daya alam.

T10: Pertanyaan mengenai peran berbagai jenis pohon naungan: Spesies pohon naungan yang mana yang direkomedasikan?

J10: Ini adalah pertanyaan yang sangat menarik untuk penelitian selanjutnya. Kami tidak dapat menemukan korelasi dalam penelitian kami yang menunjukkan efek dari jenis pohon naungan yang berbeda pada jumlah serangga hama yang berbeda. Namun demikian, akan menarik untuk mengetahui secara detail pengaruh jenis pohon naungan yang berbeda pada populasi serangga yang berdampingan dengan jenis pohon tersebut. Selain pertanyaan ini, kami menjelaskan berbagai fungsi yang diberikan oleh jenis pohon hutan atau jenis pohon berbuah (misalnya: pengaruh terhadap iklim lokal, sekuestrasi karbon, penghasilan tambahan dari penjualan buah, pemupukan nitrogen oleh pohon 
(e.g., some wild animals depend on the availability of large, remnant forest trees).

\section{Discussion Summary}

Although our research focused on the importance of birds and bats in cacao plantations in Central Sulawesi, we are very aware of the concerns of local farmers on the management of insect pests in cacao. A good cacao farm management also depends on local conditions of cacao and the structure that surrounds the plantation area.

\section{Given our research in Napu, tree cutting} management can better facilitate productivity in many cacao plantations. In addition, many cacao pests can be controlled better (e.g., against fungal infections of Phytophtora palmivora), if the farmers collect affected fruits and burn them in some distance from the plantations. Very often, the diseased fruits were just cut and dropped close to the cacao trees, which makes it easy for some major diseases to return to the tree or to affect healthy trees in the close surrounding. In addition, the soil conditions must be taken into account. If the plantation soil is too wet, the productivity of cacao trees may be less optimal or possible infection of diseases may increase.

Agricultural chemicals should be used with caution. Although none of our farmers using agricultural chemicals during our study, we observed very often that agricultural chemicals such as pesticides, herbicides and fungicides are often applied to cacao trees and greatly increase the stress of the cacao tree. These chemicals can polong-polongan) dan bagaimana pohon-pohon ini dapat dikaitkan dengan keragaman hayati hutan asli (misalnya: beberapa hewan liar bergantung pada ketersediaan pohon hutan yang besar.

\section{Ringkasan diskusi}

Meskipun penelitian kami berfokus pada pentingnya burung dan kelelawar di perkebunan kakao di Sulawesi Tengah, kami sangat menyadari keprihatinan petani lokal tentang manajemen serangga hama di perkebunan kakao. Suatu manajemen kebun kakao yang baik juga bergantung pada kondisi lokal perkebunan kakao dan struktur daerah yang mengelilingi perkebunan.

Berdasarkan hasil penelitian kami di Napu, manajemen pemangkasan pohon dapat memfasilitasi produktivitas perkebunan di banyak kebun kakao dengan lebih baik. Selain itu, banyak hama kakao bisa dikendalikan lebih baik (misalnya infeksi jamur dari Phytophtora palmivora), jika pemilik perkebunan mengumpulkan buah-buahan yang terkena penyakit dan membakarnya jauh dari perkebunan. Sangat sering, buah yang berpenyakit hanya dipotong dari pohon dan dijatuhkan dekat pohon kakao, sering memudahkan kembalinya penyakit datang ke pohon-pohon kakao atau menulari pohon lain di sekitarnya. Selain itu, kondisi tanah juga harus diperhitungkan. Jika tanah perkebunan terlalu basah, produktivitas pohon kakao mungkin kurang optimal atau kemungkinan infeksi penyakit akan meningkat.

Bahan kimia pertanian harus digunakan dengan hati-hati. Meskipun tidak ada petani dalam penelitian ini yang menggunakan bahan kimia pertanian selama penelitian, kami mengamati bahwa bahan kimia pertanian seperti pestisida, 

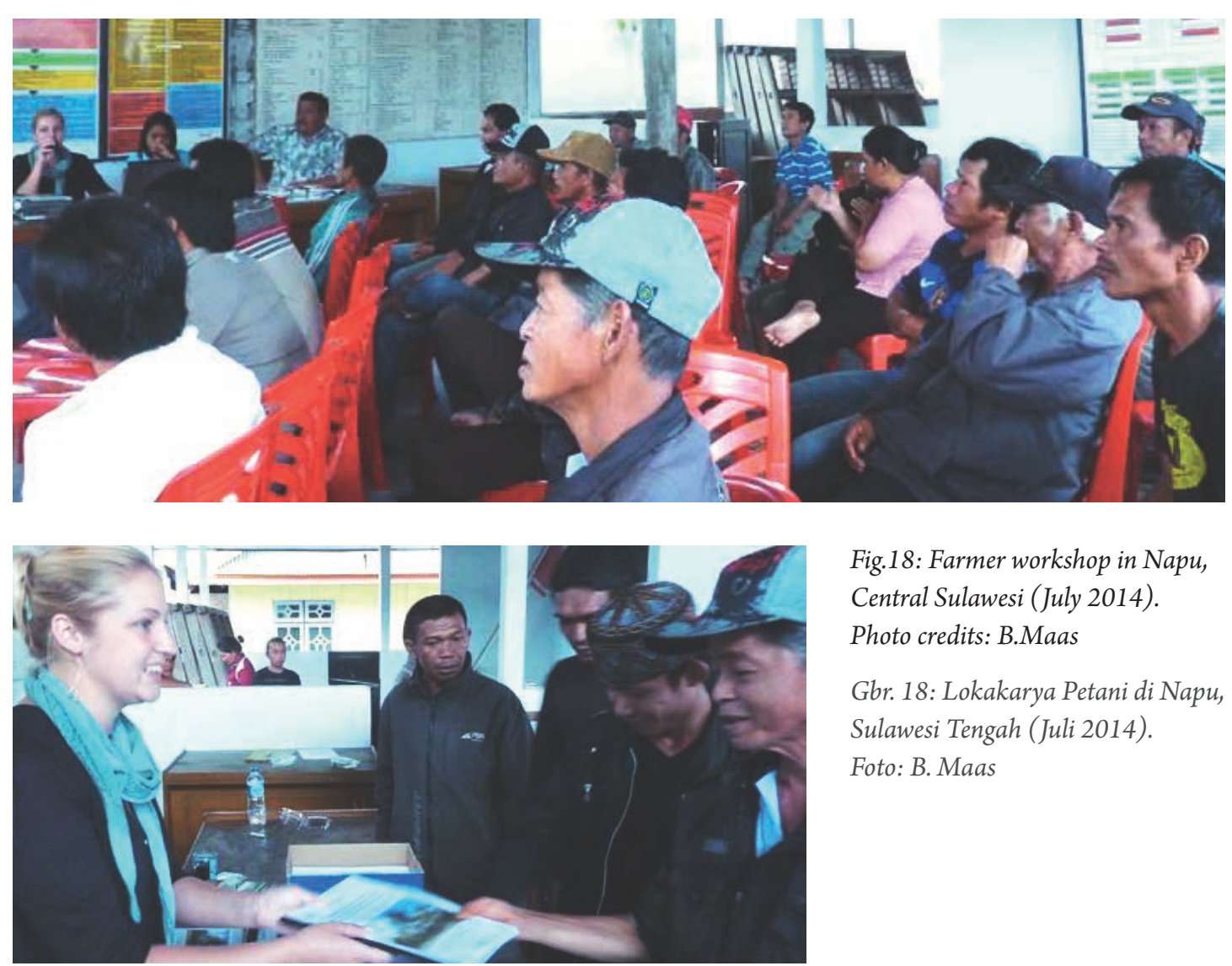

Fig.18: Farmer workshop in Napu, Central Sulawesi (July 2014).

Photo credits: B.Maas

Gbr. 18: Lokakarya Petani di Napu, Sulawesi Tengah (Juli 2014).

Foto: B. Maas

also have serious negative impacts on ground water, soil composition and fitness of the cacao tree. It is also very likely, that pesticides and other agrochemicals negatively affect the health of farmers and people living close to the application area.

In times of rapid human population growth worldwide, it is important to find possibilities of a sustainable cacao management that allows the combination of human welfare and the conservation of biodiversity and natural resources. herbisida dan fungisida sering diberikan pada pohon kakao dan sangat meningkatkan stres pada pohon kakao. Bahan-bahan kimia ini juga dapat menimbulkan dampak negatif serius pada air tanah, komposisi tanah dan kebugaran pohon kakao. Besar pula kemungkinan bahwa pestisida dan bahan kimia pertanian lain memiliki efek negatif pada kesehatan petani dan masyarakat yang tinggal di dekat daerah yang diberi pestisida.

Dalam masa pertumbuhan populasi manusia yang sangat pesat di dunia ini, penting untuk menemukan kemungkinan manajemen kakao berkelanjutan yang memungkinkan kombinasi kesejahteraan manusia dan konservasi keragaman hayati dan sumber daya alam. 

$\mathrm{I}$ $\mathrm{n}$ the following, we provide detailed information on the practical management of common cacao dieseases, provided by an Indonesian organisation that collects common techniques on farming practices and posts them on their webpage http://detiktani.

blogspot.com/. We found these management recommendations how to avoid or minimize common cacao pests very practical for cacao farmers and therefore provide them here, with kind permission from the webpage owners.
B erikut ini, kami sajikan informasi rinci tentang manajemen praktis penyakit kakao umum, yang disediakan oleh sebuah organisasi Indonesia yang mengumpulkan teknik umum pada praktik pertanian dan menuliskannya di halaman web http://detiktani.blogspot.com. Kami menemukan rekomendasi manajemen tentang bagaimana menghindari atau meminimalkan hama kakao secara praktis bagi petani kakao. Informasi ini disajikan atas izin pemilik halaman web.

\section{(1) Penyakit Kanker Batang Tanaman Kakao}

Penyakit kanker batang adalah salah satu penyakit penting bagi tanaman kakao yang disebabkan oleh infeksi cendawan Phythotora palmivora pada batang dan cabang tanaman kakao. Cendawan Phytoptora palmivora yang juga penyebab penyakit busuk buah tanaman kakao ini sering menyerang kebun kakao yang lembab dan gelap.

Penyakit kanker batang tanaman kakao dapat dikenali melalui gejala-gejala yang ditimbulkan pada batang yang terserang. Batang tanaman kakao yang terserang penyakit kanker batang memiliki bercak-cercak hitam. Bercak hitam tersebut nampak seperti basah dan membusuk. Jika tidak dikendalikan, bercak hitam akan terus meluas dan mengakibatkan terhambatnya transportasi hara dan fotosintat di dalam tanaman. Bercak hitam membusuk ditandai dengan adanya cairan merah berkarat dengan kulit kayu disekitar bagian yang membusuk berwarna coklat kemerah-merahan. 
Penyakit kanker batang kakao dapat menyebar melalui beberapa media seperti sentuhan langsung dengan buah yang terserang busuk buah, percikan air, disebarkan oleh hewan (semut atau tupai), bahkan oleh tiupan angin. Penyebaran kanker batang berbanding lurus dengan penyebaran penyakit busuk buah dan akan semakin cepat jika musim hujan dan atau jika kondisi kebun terlalu lembab. Untuk membatasi penyebaran, kondisi kelembaban kebun harus tetap dijaga agar tidak terlalu lembab dan gelap.

Penyakit kanker batang kakao dapat dikendalikan dengan mengupas kulit batang yang terserang dan membusuk hingga batas yang sehat, kemudian membalurkan air perasan kunyit pada bagian yang telah dikupas tersebut.

Jika serangan kanker batang sudah sangat akut, tanaman harus dibongkar dan bagian yang terserang harus dimusnahkan dengan cara ditimbun atau dibakar.

\section{(2) Pemangkasan Tanaman Kakao}

Pada tanaman kakao, pemangkasan penting dilakukan untuk menjaga pertumbuhan tanaman agar tetap sesuai dengan tujuan budidaya. Pemangkasan kakao dilakukan selain untuk mengkondisikan kebun agar tidak terlalu lembab, juga ditujukan agar produktivitas tanaman kakao menjadi tinggi dan menguntungkan usaha budidaya kakao.

Dalam teknisnya, pemangkasan tanaman kakao terbagi ke dalam beberapa jenis yaitu, pemangkasan bentuk, pemangkasan pemeliharaan, dan pemangkasan produksi.

\section{Pemangkasan bentuk}

Pemangkasan bentuk dilakukan dengan tujuan agar bentuk tumbuh tanaman sesuai dengan konsep budidaya pertanian dan memudahkan dalam kegiatan-kegiatan usaha budidaya. Pemangkasan bentuk dilakukan pada dua fase tanaman, yakni ketika tanaman masih muda dan ketika tanaman berada pada fase remaja.

Pemangkasan bentuk pada tanaman muda dilakukan pada saat tanaman kakao berumur antara $8 \mathrm{sd} 12$ bulan. Pemangkasan dilakukan dengan membentuk percabangan (jourquette) pada ketinggian $1 \mathrm{sd}$ 1,5 meter di atas permukaan tanah. Percabangan pada jourquette diusahakan agar hanya memiliki tiga sampai dengan empat cabang yang letaknya simetris. Tunas-tunas air yang tumbuh antara ketinggian 1 sd 1,5 meter tersebut harus dibuang agar tidak menjadi cabang baru dan akan merusak bentuk tanaman kakao yang ditanam. Cabang-cabang primer 
yang tumbuh terlalu panjang harus dipotong agar tidak saling bertumpang tindih dengan cabang-cabang primer dari tanaman di sekitarnya.

Pemangkasan bentuk pada tanaman remaja dilakukan pada saat tanaman kakao berumur antara 18 sd 24 bulan. Pemangkasan ini dilakukan dengan membuang semua cabang sekunder (cabang yang tumbuh pada cabang primer) yang tumbuh pada jarak $30 \mathrm{sd} 60 \mathrm{~cm}$ dari jorquette. Pemangkasan juga dilakukan pada cabangcabang yang tumbuh ke bawah dan mengusahakan penyebaran daun agar supaya mendapat penyinaran yang merata.

\section{Pemangkasan pemeliharaan}

Pemangkasan pemeliharaan dilakukan agar pertumbuhan tanaman kakao tetap optimal. Pemangkasan ini dilakukan dengan membuang tunas air yang tumbuh di sekitar percabangan, membuang cabang-cabang yang kering, cabang yang menggantung, saling melintang, dan bertumpang tindih.

\section{Pemangkasan produksi}

Pemangkasan produksi dilakukan dengan tujuan agar tanaman kakao dapat berproduksi secara optimal sesuai dengan kemampuannya.

Pemangkasan produksi dilakukan dengan meminimalisasi kelebatan daun melalui pembuangan daun-daun tanaman yang terlindung dari sinar matahari. Dengan pembuangan daun-daun tersebut, fotosintat yang dihasilkan dari metabolisme tanaman akan difungsikan seutuhnya untuk pembentukan buah dan bunga.

\section{(3) Penyakit Busuk Buah Kakao}

Penyakit busuk buah kakao adalah salah satu penyakit penting yang sering menyerang tanaman kakao. Penyakit ini disebabkan oleh infeksi cendawan Phythoptora palmivora pada buah. Cendawan Phythoptora palmivora sebenarnya juga dapat menginfeksi pada bagian tanaman kakao lainnya seperti batang, daun, tunas, bahkan bunga. Kendatipun demikian, dampak negatif serangan pada bagian tanaman lainnya tersebut tidak sebesar jika cendawan ini menginfeksi buah.

Penyakit busuk buah kakao sering menyerang tanaman yang memiliki sistem kekebalan yang rentan serta ditunjang oleh keberadaan kebun yang lembab dan gelap. Gejala serangan penyakit busuk buah adalah timbulnya bercak-bercak hitam pada bagian kulit luar buah. Bercak-bercak hitam tersebut akan meluas hingga menutupi semua bagian kulit buah jika tidak segera dikendalikan. Penyakit ini dapat 
menyerang semua fase pertumbuhan buah, mulai dari buah pentil hingga buah dalam fase kemasakan. Buah yang terserang penyakit ini akan tampak hitam arang dan jika disentuh akan terasa basah membusuk. Penyakit ini dapat menyebar dari satu buah yang terinfeksi ke buah lainnya melalui beberapa media seperti sentuhan langsung antar buah, percikan air, dibawa oleh hewan (semut atau tupai), bahkan oleh tiupan angin. Penyebaran busuk buah akan semakin cepat jika kondisi kebun terlalu lembab karena cendawan Phythoptora palmivora dapat tumbuh subur pada daerah yang lembab.

\section{(4) Penghisap Buah Kakao (Helopeltis spp.)}

Penghisap buah kakao (Helopeltis spp.) adalah hama penting bagi usaha budidaya tanaman kakao yang dapat menimbulkan kerusakan pada beberapa bagian tanaman seperti buah, daun muda, hingga kuncup buah. Hama yang termasuk ke dalam familo miridae dan ordo hemiptera ini menyerang dengan cara menghisap bagian-bagian tanaman tadi menggunakan mulutnya. Bekas hisapan pada bagian tanaman tersebut biasanya akan meninggalkan bekas berupa bercak-bercak hitam. Bercak tersebut timbul akibat cairan ludah yang dikeluarkan serangga ini ketika akan menghisap. Serangga penghisap buah ini dapat menyebabkan kerusakan yang lebih besar jika terjadi infeksi atau menjadi vektor beberapa jamur penyebab penyakit tanaman seperti jamur Fusarium solani, Aspergilus spp., Glomella cingulata, Botryodiploida theobromae, dan Penicillium janthinellum.

\section{Siklus hidup}

Penghisap buah kakao (Helopeltis spp.) tersebar di beberapa negara penghasil kakao seperti Malaysia, Indonesia, Afrika Barat, Afrika Timur, Papua Nugini, dan Amerika Selatan. Hingga saat ini Helopeltis spp. diketahui terdiri dari 13 spesies yang 2 spesies diantaranya terdapat di Indonesia. Kedua spesies tersebut adalah H. antonii Sign. dan H. theivora Watt.

Imago Helopeltis spp. dapat diidentifikasi dari beberapa penampilan fisiknya, antara lain terdapatnya jarum penusuk pada mesoskutelumnya, berwarna coklat kehitamhitaman pada serangga jantan, berwarna coklat kemerah-merahan pada serangga betina, tungkai berwarna coklat kelabu, punggung berwarna hijau kelabu, dan panjang tubuhnya $6,5 \mathrm{sd} 7,5 \mathrm{~mm}$. Serangga yang tumbuh optimal pada ketinggian 200 sd 1.400 meter di atas permukaan laut ini, dapat hidup sampai 50 hari.

Imago betina dapat bertelur sebanyak 235 butir selama 34 hari. Telur tersebut biasanya diletakan di permukaan buah muda. Telur berbentuk lonjong berwarna putih dengan panjang sekitar $1 \mathrm{~mm}$. 
Telur menetas dan menjadi nimfa setelah 6 sd 8 hari setelah diletakkan. Nimfa yang keluar berbulu halus dan belum memiliki jarum. Nimfa tersebut akan dewasa setelah mengalami 4 kali ganti kulit dan jarum akan mulai nampak ketika ganti kulit pertama pada nimfa. Periode nimfa biasanya berlangsung selama $12 \mathrm{sd} 14$ hari sebelum kemudian berubah menjadi serangga dewasa (imago).

Populasi dan serangan hama penghisap buah kakao umumnya meningkat saat musim hujan karena pada musim hujan intensitas penyinaran matahari semakin kecil, kelembaban udara semakin tinggi, dan kecepatan angin semakin rendah. Kondisi seperti ini sangat cocok untuk pertumbuhan dan perkembangan hama ini.

\section{Pengendalian}

Helopeltis spp. dapat dikendalikan dengan berbagai cara-cara seperti pengendalian hayati, pengendalian kultur teknis, dan juga pengendalian secara kimiawi.

\section{(a) Pengendalian kultur teknis}

Pengendalian kultur teknis merupakan pengendalian yang paling efektif dalam menurunkan intensitas serangan hama penghisap buah kakao. Pengendalian dengan cara ini dilakukan dengan menerapkan panen sering untuk memutus siklus hidupnya pada stadia telur, pemupukan berimbang untuk meningkatkan sestem kekebalan tanaman, kondomisasi buah kecil menggunakan plastik, dan pemangkasan teratur untuk membuar agar kondisi kebun tidak disukai oleh hama ini.

\section{(b) Pengendalian hayati}

Pengendalian hayati dapat dilakukan dengan melepaskan beberapa musuh alami Helopeltis seperti belalang sembah, kepik predator, laba-laba, dan semut hitam. Pelepasan semut hitam merupakan teknik pengendalian hayati yang paling sering digunakan hingga saat ini. Untuk membuat semut hitam dapat hidup dengan optimal dikebun perlu dilakukan beberapa cara seperti inokulasi kutu putih dan pembuatan sarang dari seresah daun pada pecabangan tanaman (jorquette).

Informasi tentang penyakit kakao dan manajemennya dapat dilihat di:

\section{http://detiktani.blogspot.com/}





\section{3}

\section{Explanation of Important Key Words of This Guide}

In the Indonesian version of this booklet (see right side), we provide a more detailed and comprehensive explanation of the terms agroforestry, ecosystem services, predator and food web based on our experience, that these terms were often poorly or differently understoof by local cacao farmers or stakeholders in Central Sulawesi. Therefore, all terms are explained according to common scientific definitions, together with simple examples (e.g. a predator is an insectivorous bird that eats insects and other arthropods) and processes (e.g. within a food web, there are top predators, mesopredators and primary consumers) to make the basic questions of our research more understandbale for farmers.

\section{Penjelasan Istilah yang Digunakan dalam Buku Ini}

Agroforestri adalah sistem agroforestri di negara tropis termasuk kebun kakao, kebun kopi dan kelapa sawit. "Agroforestri” adalah manajemen pertanian dengan pohon-pohon dan kayu besar, dengan tanaman jenis kayu yang berumur panjang dan yang bisa dicampur dengan tanaman lain. Tergantung dari manajemen lokal (jenis pohon naungan yang dipilih) dan manajemen daerah (jarak dengan hutan primer), sistem agroforestri itu bisa bermanfaat untuk “jasa ekosistem” alami.

Jasa Ekosistem diartikan sebagai fungsi alami dari ekosistem yang dapat bermanfaat untuk manusia. Jasa ini termasuk air bersih (bersih karena banyak proses dan fungsi alami di dalam air), iklim (termasuk fungsi dari hutan primer), tanah (yang bisa regulasi dan tertransformasi sendiri), tempat rekreasi untuk manusia (hutan, daerah alami) dan banyak sekali servis alami yang lain. Jasa ekosistem yang paling penting di negara tropis yaitu "pengendalian hama alami” (mengurangi jumlah serangga hama) yang diberikan oleh pemangsa alami, termasuk burung dan kelelawar. 
Pemangsa atau "predator" adalah binatang yang memakan binatang lain (yang berada di bawah mereka pada jaring makanan) dan mampu mengurangi jumlah serangga yang berbeda (termasuk serangga hama). Ini merupakan "jasa ekosistem” yang penting di negara tropis dan yang dapat bermanfaat untuk manusia. Misalnya: Jenis burung dan kelelawar makan serangga hama di kebun kakao. Dengan cara ini mereka berkontribusi pada jasa ekosistem "pengendalian hama alami".

Rantai makanan dan Jaring makanan. Rantai makanan adalah peristiwa makan-memakan antara makhluk hidup dengan urutan (hirarki) tertentu. Dalam rantai makanan ada makhluk hidup yang berperan sebagai produsen (penghasil), konsumen (pengguna), serta dekomposer (pengurai). Pada rantai makanan tersebut terjadi proses makan dan dimakan dalam urutan tertentu. Tiap tingkat dari rantai makanan dalam suatu ekosistem disebut tingkat trofik.
Tingkat trofik adalah tingkat dalam rantai makanan di mana suatu organisme memperoleh energi. Pada tingkat trofik pertama adalah organisme yang mampu menghasilkan zat makanan sendiri yaitu tumbuhan hijau atau organisme autotrof (produsen). Organisme yang menduduki tingkat tropik kedua disebut konsumen primer (konsumen I). Konsumen I biasanya diduduki oleh hewan herbivora (misalnya semut). Organisme yang menduduki tingkat tropik ketiga disebut konsumen sekunder (Konsumen II), diduduki oleh hewan pemakan daging misalnya burung dan kelelawar. Dan organisme yang menduduki tingkat tropik tertinggi disebut konsumen puncak (top predator). 


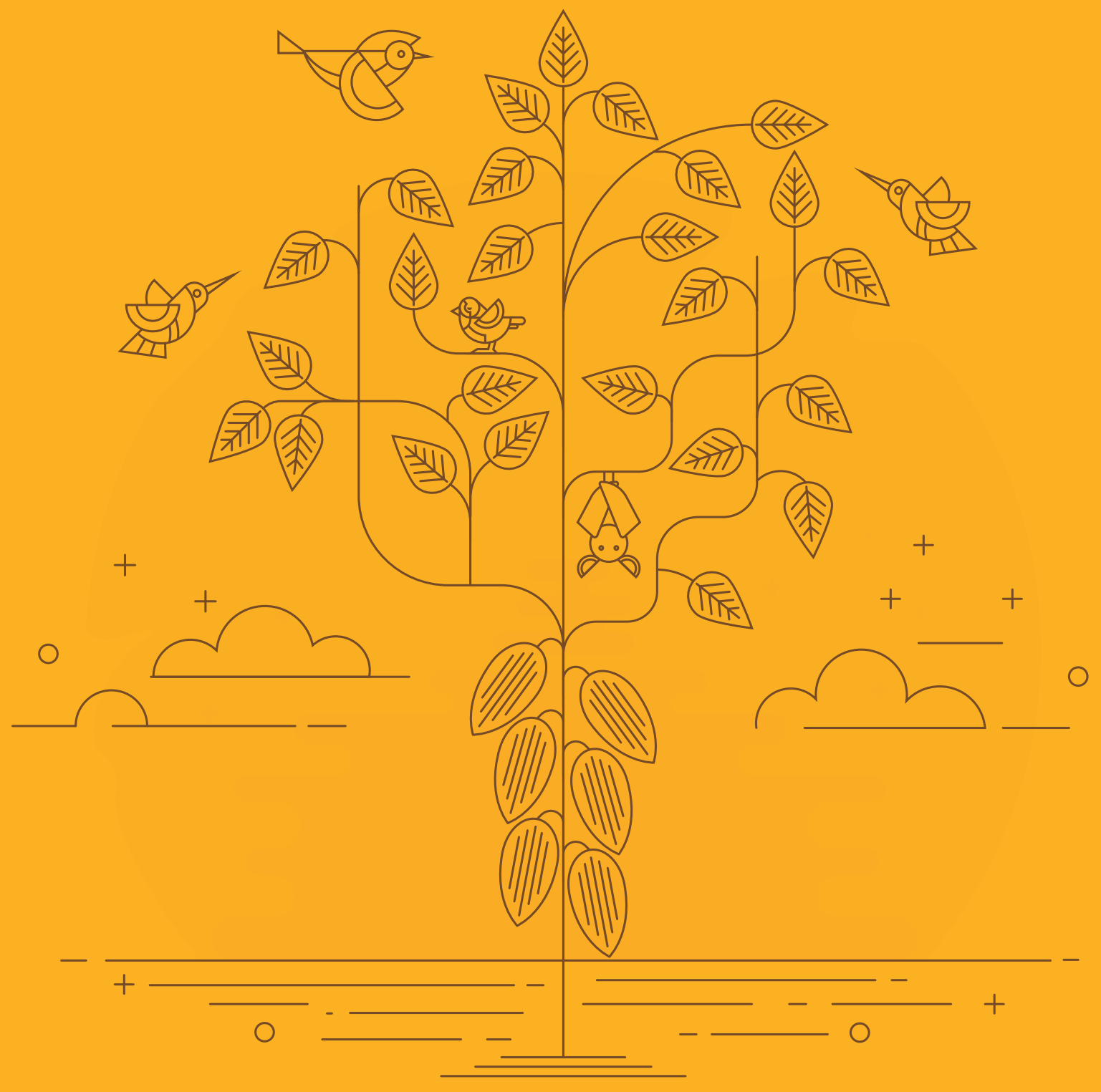





\section{Publication List \\ (2002-2015) -}

\section{Research in Sulawesi}

Result of the cooperation of

Agroecology Group in Germany

and Tadulako University

in Indonesia

\section{Daftar Publikasi \\ (2002-2015) - \\ Penelitian di Sulawesi}

\author{
Hasil kerjasama Kelompok \\ Agroekologi di Jerman dan \\ Universitas Tadulako di Indonesia
}

Klein, A.M, Steffan-Dewenter, I., Buchori, D., Tscharntke, T. (2002): Effects of land-use intensity in tropical agroforestry systems on coffee flower-visiting and trap-nesting bees and wasps. Conservation Biology Vol. 11: 683-693.

Klein, A.M., Steffan-Dewenter, I., Tscharntke, T. (2002): Predator-prey ratios on cacao along a landuse gradient in Indonesia. Biodiversity and Conservation Vol. 11: 683-693.

Klein, A.M., Steffan-Dewenter, I., Tscharntke, T. (2003a): Bee pollination and fruit set of Coffea arabica and C. canephora (Rubiaceae). American Journal of Botany Vol. 90: 153-157.

Klein, A.M., Steffan-Dewenter, I., Tscharntke, T. (2003b): Pollination of Coffea canephora in relation to local and regional agroforestry management. Journal of Applied Ecology Vol. 40: 837-845.

Klein, A.M., Steffan-Dewenter, I., Tscharntke, T. (2003c): Fruit set of highland coffee increases with the diversity of pollinating bees. Proceedings of the Royal Society of London Series B Vol. 270: 955-961.

Klein, A.M., Steffan-Dewenter, I., Tscharntke, T. (2004): Foraging trip duration and density of megachilid bees, eumenid wasps and pompilid wasps in tropical agroforestry systems. Journal of Animal Ecology Vol. 73: 517-525.

Schulze, C.H., Waltert, M., Kessler, P.J.A., Pitopang, R., Shahabuddin, Veddeler, D., Mühlenberg, M., Gradstein, S.R., Leuschner, C., Steffan-Dewenter, I., Tscharntke, T. (2004): Biodiversity indicator groups of tropical land-use systems: comparing plants, birds, and insects. Ecological Applications Vol. 14: 1321-1333.

Schulze, C.H., Steffan-Dewenter, I., Tscharntke, T. (2004): Effects of land use on butterfly communities at the rain forest margin: A case study from Central Sulawesi. In: Gerold, G., Fremerey, M, Guhardja, E. (eds.): Land Use, Nature Conservation, and the Stability of Rainforest Margins in Southeast Asia. Springer-Verlag, Berlin, Heidelberg, New York, 281-297.

Shahabuddin, Schulze, C.H., Tscharntke, T. (2005): Changes of dung beetle communities from rainforests towards agroforestry systems and annual cultures In Sulawesi (Indonesia). Biodiversity and Conservation Vol. 14: 863-877. 
Veddeler, D., Schulze, C.H., Steffan-Dewenter, I., Buchori, D., Tscharntke, T. (2005): The contribution of tropical secondary forest fragments to the conservation of fruit-feeding butterflies: effects of isolation and age. Biodiversity and Conservation Vol. 14: 3577-3592.

Tscharntke, T., Klein, A.M., Kruess, A., Steffan-Dewenter, I., Thies, C. (2005): Landscape perspectives on agricultural intensification and biodiversity - ecosystem service management. Ecology Letters Vol. 8: 857-874.

Bos, M.M., Hoehn, P., Saleh. S., Büche, B., Buchori, D., Steffan-Dewenter, I., Tscharntke, T. (2007): Insect diversity responses to forest conversion and agroforestry management. In: Tscharntke, T., Leuschner, C., Zeller, M., Guhardja, E., Bidin, A. (eds) (2007): The stability of tropical rainforest margins, linking ecological, economic and social constraints of land use and conservation. Springer Verlag, Berlin, pp 279-296.

Olschewski, R., Tscharntke, T., Benítez, P.C., Schwarze, S., Klein, A.-M. (2007): Economic evaluation of ecosystem services as a basis for stabilizing rainforest margins? The example of pollination services and pest management in coffee landscapes. In: Tscharntke, T., Leuschner, C., Zeller, M., Guhardja, E., Bidin, A. (eds) (2007): The stability of tropical rainforest margins, linking ecological, economic and social constraints of land use and conservation. Springer Verlag, Berlin, pp 265-278.

Tscharntke, T., Leuschner, C., Zeller, M., Guhardja, E., Bidin, A. (eds) (2007): The stability of tropical rainforest margins, linking ecological, economic and social constraints of land use and conservation. Springer Verlag, Berlin, pp 513.

Tscharntke, T., Leuschner, C., Zeller, M., Guhardja, E., Bidin, A. (2007): The stability of tropical rainforest margins, linking ecological, economic and social constraints of land use and conservation - an introduction. In: Tscharntke, T., Leuschner, C., Zeller, M., Guhardja, E., Bidin, A. (eds) (2007): The stability of tropical rainforest margins, linking ecological, economic and social constraints of land use and conservation. Springer Verlag, Berlin, pp 1-8.

Steffan-Dewenter, I., Klein, A.-M., Gaebele, V., Alfert, T., Tscharntke, T. (2006) Bee diversity and plant-pollinator interactions in fragmented landscapes. In Plant-Pollinator Interactions: From Specialization to Generalization (Waser, N.M. and Ollerton, J., eds), pp. 387-407, University of Chicago Press

Olschewski, R., Tscharntke, T., Benítez, P. C., Schwarze, S., Klein, A. M. (2006): Economic valuation of pollination services and pest management comparing coffee landscapes in Ecuador and Indonesia. Ecology and Society 11 (1): 1-7.

Klein, A.M., Steffan-Dewenter, I., Tscharntke, T. (2006): Rainforest promote trophic interactions and diversity of trap-nesting Hymenoptera in adjacent agroforestry . Journal of Animal Ecology Vol. 75: 315-323. 
Bos, M.M., Veddeler, D., Bogdanski, A.K., Klein, A.M., Tscharntke, T., Steffan-Dewenter, I., Tylianakis, J.M.(2007): Caveats to quantifying ecosystem services: fruit abortion blurs benefits from crop pollination. Ecological Applications Vol .17: 1841-1849.

Bos, M.M., Steffan-Dewenter, I., Tscharntke, T. (2007) The contribution of cacao agroforests to the conservation of lower canopy ant and beetle diversity in Indonesia. Biodiversity and Conservation Vol. 16: 2429-2444.

Sporn, S.G., Bos, M.M., Gradstein, S.R. (2007): Is productivity of cacao impeded by epiphytes? An experimental approach. Agriculture, Ecosystems and Environment Vol. 122: 190-193.

Priess, J., Mimler, M., Klein, A.M., Schwarze, S., Tscharntke, T., Steffan-Dewenter I. (2007): Linking deforestation scenarios to pollination services and economic returns in coffee agroforestry systems. Ecological Applications Vol. 17, 407-417.

Steffan-Dewenter, I., Kessler, M., Barkmann, J., Bos, M.M., Buchori, D., Erasmi, S., Faust, H., Gerold, G., Glenk, K., Gradstein, S.R., Guhardja, E., Harteveld, M., Herteld, D., Hohn, P., Kappas, M., Kohler, S., Leuschner, C., Maertens, M., Marggraf, R., Migge-Kleian, S., Mogea, J., Pitopang, R., Schaefer, M., Schwarze, S., Sporn, S.G., Steingrebe, A., Tjitrosoedirdjo, S.S., Tjitrosoemito, S., Twele, A., Weber, R., Woltmann, L., Zeller, M., Tscharntke, T. (2007): Tradeoffs between income, biodiversity, and ecosystem functioning during tropical rainforest conversion and agroforestry intensification. Proceedings of the National Academy of Sciences of the United States of America Vol. 104, 4973-4978.

Bos, M.M., Steffan-Dewenter, I., Tscharntke, T. (2007): Shade tree management affects fruit abortion, insect pests and pathogens of cacao. Agriculture, Ecosystems and Environment Vol. 120: 201-205.

Nässig, W.A., Schulze, C.H. (2007): A second species with diurnal males of the genus Eupterote from Indonesia: Eupterote (Eupterote) splendens n. sp. from Sulawesi (Insecta, Lepidoptera, Bombycoidea, Eupterotidae). Senckenbergiana biologica, Frankfurt am Main Vol. 87: 189-194.

Klein, A.M., Vaissière, B.E., Cane, J.H., Steffan-Dewenter, I., Cunningham, S.A., Kremen, C., Tscharntke, T. (2007): Importance of pollinators in changing landscapes for world crops. Proceedings of the Royal Society B Vol. 274: 303-313.

Shahabuddin, Manuwoto S, Hidayat P, Schulze CH \& Noerdjito WA (2007): Respons kumbang koprofagus (Coleoptera: Scarabaeidae) terhadap perubahan struktur vegetasi pada beberapa tipe habitat di Taman Nasional Lore Lindu, Sulawesi Tengah. [Response of coprophagus beetles (Coleoptera: Scarabaeidae) to changes of vegetation structure in various habitat types at Lore Lindu National Park, Central Sulawesi.] Biodiversitas Vol. 7: 360-365. 
Tylianakis, J., Rand, T., Kahmen, A., Klein, A.M., Buchmann, N., Perner, J., Tscharntke, T. (2008):

Resource heterogeneity moderates the diversity-function relationship in the real world. PloS Biology Vol. 6 (5) e122, 947-956.

Hoehn, P., Tscharntke, T., Tylianakis, J.M., Steffan-Dewenter, I. (2008): Functional group diversity of bee pollinators increases crop yield. Proceedings of the Royal Society B Vol. 275: 2283-2291

Tscharntke, T., Sekercioglu, C.H., Dietsch, T.V., Sodhi, N.S., Hoehn, P.H., Tylianakis, J.M. (2008): Landscape constraints on functional biodiversity of birds and insects in tropical agroecosystems. Ecology Vol. 89: 944-951.

Klein, A.M., Cunningham, S.A., Bos, M., Steffan-Dewenter, I. (2008): Advances in pollination ecology from tropical plantation crops. Ecology Vol. 89: 935-943.

Bos, M.M., Tylianakis, J.M., Steffan-Dewenter, I., Tscharntke, T. (2008): The invasive Yellow Crazy Ant and the decline of forest ant diversity in Indonesian cacao agroforests. Biological Invasions: Biological Invasions Vol. 10: 1399-1409.

Abrahamczyk, S., Kessler, M., Dadang, D.P., Waltert, M. \& Tscharntke, T. (2008): The value of differently managed cacao plantations for forest bird conservation in Sulawesi, Indonesia. Bird Conservation International Vol. 18: 349-362.

Clough, Y., Dwi Putra, D., Pitopang, R., Tscharntke, T. (2009): Local and landscape factors determine functional bird diversity in Indonesian cacao agroforestry . Biological Conservation Vol. 142: 1032-1041.

Klein, A.M., Olschewski, R., Kremen, C. 2008. The ecosystem service controversy: is there sufficient evidence for a 'pollination paradox'? GAIA Vol. 17, 12-16.

Wanger, T.C., Saro, A., Iskandar, D.T., Brook, B.W., Sodhi, N.S., Clough, Y., Tscharntke, T. (2009): Conservation value of cacao agroforestry for amphibians and reptiles in South-East Asia: combining correlative models with follow-up field experiments. Journal of Applied Ecology Vol. 46: 823-832.

Klein, A.M., Müller, C.M., Hoehn, P., Kremen, C. 2009. Understanding the role of species richness for crop pollination services. In: Daniel Bunker, Andy Hector, Michel Loreau, Charles Perrings, Shahid Naeem (eds.) The consequences of changing biodiversity -solutions and scenarios, Oxford University Press, pp. 195-208.

Klein A.M (2009): Nearby rainforest promotes coffee pollination by increasing spatio-temporal stability in bee species richness. Forest Ecology and Management doi:10.1016/j. foreco.2009.05.005 (published online).

Hoehn, P., Steffan-Dewenter, I., Buchori, D., Tscharntke, T. (2009): Spatiotemporal density patterns of the pest predator Rhynchium haemorrhoidale (F.) along a land-use gradient in cacao agroforestry systems. Agroforestry Systems DOI 10.1007/s10457-008-9154-1 (published online). 
Kessler, M., Abrahamczyk, S., Bos, M., Buchori, D., Putra, D.D., Gradstein, S.R., Hoehn, P., Kluge, J., Orend, F., Pitopang, R., Saleh, S., Schulze, C.H., Sporn, S.G., Steffan-Dewenter, I., Tscharntke, T. (2009): Alpha and Beta Diversity of Plants and Animals along a Tropical Land-use Gradient. Ecological Applications (in press).

Ariyanti, N.S., Bos, M.M., Kartawinata, K., Tjitrosoedirdjo, S.S., Guhardja, E., Gradstein, S.R. (2009). Bryophytes on tropical tree-trunks: Effects of forest disturbance and cacao agroforestry in Central Sulawesi, Indonesia. Biological Conservation Vol. 141: 2516-2527.

Maas B., Putra D.D., Waltert M., Clough, Y., Tscharntke T. Schulze C. (2009): Six years of habitat modification in a tropical rainforest margin of Indonesia do not affect bird diversity but endemic forest species. Biological Conservation Vol. 142: 2665-2671.

Clough, Y., Faust, H., Tscharntke, T. (2009): Cacao boom, cacao bust: endangered sustainability and opportunities for biodiversity conservation. Conservation Letters DOI: 10.1111/j.1755263X.2009.00072.x (published online).

Schwendenmann, L., Veldkamp, E., Moser, G., Hölscher, D., Anas, I., Clough, Y., Djajakirana, G., Erasmi, S., Hendrayanto, Hertel, D., Köhler, M., Leitner, D., Leuschner, Ch., Michalzik, B., Propastin, P., Tjoa, A., Tscharntke, T., van Straaten, O. (2009): Effects of an experimental drought on a cacao agroforestry system, Sulawesi, Indonesia. Global Change Biology (in press).

Shahabuddin, Hidayat, P., Manuwoto, S., Noerdjito, W.A., Tscharntke, T., Schulze, C.H. (2009) Biodiversity and body size of dung beetles colonizing introduced vs. endemic dung along a tropical land-use gradient. Journal of Tropical Ecology (in press).

Clough, Y., Abrahamczyk, S., Adams, M.O., Anshary, A., Ariyanti, N., Betz, L., Buchori, D., Cicuzza, D., Darras, K., Dwi Putra, D., Fiala, B., Gradstein, S.R., Kessler, M., Klein, A.M., Pitopang, R., Sahari, B., Scherber, C., Schulze, C.H., Shahabuddin, Sporn, S., Stenchly, K., Tjitrosoedirdjo, S.S., Wanger, T.C., Weist, M., Wielgoss, A., Tscharntke, T. (2010). Biodiversity patterns and trophic interactions in human-dominated tropical landscapes in Sulawesi (Indonesia): plants, arthropods and vertebrates. In Tscharntke, T., Leuschner, C., Veldkamp, E., Faust, H., Guhardja, E., Bidin, A. (eds.) Tropical rainforests and agroforests under global change. Environmental Science and Engineering Series, Springer Verlag, Berlin, Germany (in press). ISBN: 978-3-642-00492-6.

Teodoro AV, Sousa-Souto L, Klein A-M, Tscharntke T (2010): Seasonal Contrasts in the Response of Coffee Ants to Agroforestry Shade-Tree Management. Environmental Entomology Vol. 39: 1744-1750.

Weist M, Tscharntke T, Sinaga MH, Maryanto I, Clough Y (2010): Effect of distance to forest and habitat characteristics on endemic versus introduced rat species in agroforest landscapes of Central Sulawesi, Indonesia. Mammalian Biology Vol. 75: 567-571. 
Sodhi NS, Koh LP, Clements R, Wanger TC, Hill JK, Hamer KC, Clough Y, Tscharntke T, Posa MRC, Lee TM (2010): Conserving Southeast Asian forest biodiversity in humanmodified landscapes. Biological Conservation Vol. 143: 2375-2384.

Wanger TC, Iskandar DT, Motzke I, Brook BW, Sodhi NS, Clough Y, Tscharntke T (2010): Effects of land-use change on community composition of tropical amphibians and reptiles in Sulawesi, Indonesia. Conservation Biology Vol. 24: 795-802.

Groeneveld JH, Tscharntke T, Moser G, Clough Y (2010): Experimental evidence for stronger cacao yield limitation by pollination than by plant resources. Perspectives in Plant Ecology, Evolution and Systematics Vol. 12: 183-191.

Clough Y, Abrahamczyk S, Adams M-O, Anshary A, Ariyanti N, Betz L, Buchori D, Cicuzza D, Darras K, Putra DD, Fiala B, Gradstein SR, Kessler M, Klein A-M, Pitopang R, Sahari B, Scherber C, Schulze CH, Shahabuddin, Sporn S, Stenchly K, Tjitrosoedirdjo SS, Wanger TC, Weist M, Wielgoss A, Tscharntke T (2010): Biodiversity patterns and trophic interactions in human-dominated tropical landscapes in Sulawesi (Indonesia): plants, arthropods and vertebrates. In: Tscharntke T, Leuschner C, Veldkamp E, Faust H, Guhardja E, Bidin A (eds) (2010): Tropical Rainforests and Agroforests under Global Change. Ecological and Socio-economic Valuations. Springer Verlag, Berlin, pp 15-71.

Tscharntke T, Leuschner C, Veldkamp E, Faust H, Guhardja E, Bidin A (2010): Tropical rainforests and agroforests under global change: Ecological and socio-economic valuations - an introduction. In: Tscharntke T, Leuschner C, Veldkamp E, Faust H, Guhardja E, Bidin A (eds) (2010): Tropical Rainforests and Agroforests under Global Change. Ecological and Socio-economic Valuations. Springer Verlag, Berlin, pp 1-11.

Tscharntke T (2010): Ecosystem services and agroecosystems in a landscape context. In: Sodhi NS, Ehrlich PR (eds) (2010): Conservation Biology for All. Oxford University Press, pp 55-57. Stenchly K, Clough Y, Buchori D, Tscharntke T (2011): Spider web guilds in cacao agroforestry comparing tree, plot and landscape-scale management. Diversity and Distributions 17: $748-756$.

Clough Y, Barkmann J, Juhrbandt J, Kessler M, Wanger TC, Anshary A, Buchori D, Cicuzza D, Darras D, Dwi Putra D, Erasmi S, Pitopang R, Schmidt C, Schulze CH, Seidel D, Steffan-Dewenter I, Stenchly K, Vidal S, Weist M, Wielgoss AC, Tscharntke T (2011): Combining high biodiversity with high yields in tropical agroforests. PNAS 108: 8311-8316.

Kessler M, Abrahamczyk S, Bos M, Buchori D, Dwi Putra D, Gradstein RS, Höhn P, Kluge J, Orend F, Pitopang R, Shahabuddin S, Schulze CH, Sporn SG, Steffan-Dewenter I, Tjitrosoedirdjo SS, Tscharntke T (2011): Cost-effectiveness of plant and animal biodiversity indicators in tropical forest and agroforest habitats. Journal of Applied Ecology Vol. 48: 330-339. 
Wanger TC, Motzke I, Shahabuddin S, Iskandar DT (2011): The amphibians and reptiles of the Lore Lindu National Park area, Central Sulawesi, Indonesia. Salamandra Vol. 47: 17-29. OPEN ACCESS

Tscharntke T, Clough Y, Bhagwat SA, Buchori D, Faust H, Hertel D, Hölscher D, Juhrbandt J, Kessler M, Perfecto I, Scherber C, Schroth G, Veldkamp E, Wanger TC (2011): Multifunctional shade-tree management in tropical agroforestry landscapes - a review. Journal of Applied Ecology Vol. 48: 619-629. Supporting Information.

Wanger TC, Wielgoss AC, Motzke I, Clough Y, Brook BW, Sodhi NS, Tscharntke T (2011): Endemic predators, invasive prey and native diversity. Proceedings of the Royal Society B Vol. 278: 690-694. OPEN ACCESS

Tscharntke T, Batáry P, Clough Y, Kleijn D, Scherber C, Thies C, Wanger TC, Westphal C (2012): Combining biodiversity conservation with agricultural intensification. Book chapter in: Lindenmayer D, Cunningham S, Young A (2012) Land Use Intensification. Effects on Agriculture, Biodiversity and Ecological Processes. CRC Press / CSIRO Publishing, ISBN 9780643104075.

Kessler M, Hertel D, Jungkunst HF, Kluge J, Abrahamczyk S, Bos M, Buchori D, Gerold G, Gradstein SR, Köhler S, Leuschner C, Moser G, Pitopang R, Saleh S, Schulze CH, Sporn SG, Steffan-Dewenter I, Tjitrosoedirdjo SS, Tscharntke T (2012):Can Joint Carbon and Biodiversity Management in Tropical Agroforestry Landscapes Be Optimized? PLOS ONE 7. OPEN ACCESS

Jackson LE, Pulleman MM, Brussaard L, Bawa KS, Brown GG, Cardoso IM, de Ruiter PC, GarcíaBarrios L, Hollander AD, Lavelle P, Ouédraogo E, Pascual U, Setty S, Smukler SM, Tscharntke T, Van Noordwijk M (2012): Social-ecological and regional adaptation of agrobiodiversity management across a global set of research regions. Global Environmental Change Vol. 22: 623-639.

Schleuning M, Fründ J, Klein AM, Abrahamczyk S, Alarcón R, Albrecht M, Andersson GKS, Bazarian S, Böhning-Gaese K, Bommarco R, Dalsgaard B, Dehling DM, Gotlieb A, Hagen M, Hickler T, Holzschuh A, Kaiser-Bunbury CN, Kreft H, Morris RJ, Sandel B, Sutherland WJ, Svenning J-C, Tscharntke T, Watts S, Weiner CN, Werner M, Williams NM, Winqvist C, Dormann CF, Blüthgen N (2012): Specialization of Mutualistic Interaction Networks Decreases toward Tropical Latitudes. Current Biology Vol. 22: 1-7. Supplementary Information highlighted in Current Biology | Dispatch: 22, pp. R914-R915 (6 Nov 2012)

Laurance WF et al. (2012): Averting biodiversity collapse in tropical forest protected areas. Nature Vol. 489: 290-294. DOI:10.1038/nature11318. Supplementary Information 
Tscharntke T, Clough Y, Wanger TC, Jackson L, Motzke I, Perfecto I, Vandermeer J, Whitbread A (2012): Global food security, biodiversity conservation and the future of agricultural intensification. Biological Conservation Vol. 151: 53-59. Recommended by the F1000 Faculty

Wielgoss A, Clough Y, Fiala B, Rumede A, Tscharntke T (2012): A minor pest reduces yield losses by a major pest:plant-mediated herbivore interactions in Indonesian cacao. Journal of Applied Ecology Vol. 49: 465-473.

Tscharntke T, Tylianakis JM, Rand TA, Didham RK, Fahrig L, Batáry P, Bengtsson J, Clough Y, Crist TO, Dormann CF, Ewers RW, Fründ J, Holt RD, Holzschuh A, Klein AM, Kleijn D, Kremen C, Landis DA, Laurance W, Lindenmayer D, Scherber C, Sodhi N, SteffanDewenter I, Thies C, van der Putten WH, Westphal C (2012): Landscape moderation of biodiversity patterns and processes - eight hypotheses. Biological Reviews Vol. 87: 661685. Recommended by the F1000 Faculty

Stenchly K, Clough Y, Tscharntke T (2012): Spider species richness in cocoa agroforestry systems, comparing vertical strata, local management and distance to forest. Agriculture, Ecosystems \& Environment Vol. 149: 189-194.

Maas B, Clough Y, Tscharntke T (2013): Bats and birds increase crop yield in tropical agroforestry landscapes. Ecology Letters Vol. 16:1480-1487.

Motzke I, Tscharntke T, Sodhi NS, Klein AM, Wanger TC (2013): Ant seed predation, pesticide applications and farmers' income from tropical multi-cropping gardens. Agricultural and Forest Entomology Vol. 15 (3): 245-254.

Rizali A, Clough Y, Buchori D, Tscharntke T (2013): Dissimilarity of Ant Communities Increases with Precipitation, but not Reduced Land-Use Intensity, in Indonesian Cacao Agroforestry . Diversity Vol. 5: 26-38; doi:10.3390/d5010026 OPEN ACCESS

Rizali A, Clough Y, Buchori D, Hosang MLA, Bos MM, Tscharntke T (2013): Long-term change of ant community structure in cacao agroforestry landscapes in Indonesia. Insect Conservation and Diversity Vol. 6(3): 328-338.

Gonthier DJ, Ennis KK, Farinas S, Hsieh H-Y, Iverson AL, Batáry P, Rudolphi J, Tscharntke T, Cardinale BJ, Perfecto I (2014): Biodiversity conservation in agriculture requires a multiscale approach. Proceedings of the Royal Society B Vol. 281: DOI: 10.1098/rspb.2014.1358

Wanger TC, Tscharntke T, Schroth G, Klein AM (2014): Pollination curbs climate risk to cocoa. Nature Vol. 511: 155. 
Wanger TC, Darras K, Bumrungsri S, Tscharntke T, Klein AM (2014): Bat pest control contributes to food security in Thailand. Biological Conservation Vol. 171: 220-223.

Wielgoss A, Tscharntke T, Rumede A, Fiala B, Seidel H, Shahabuddin S, Clough Y (2014): Interaction complexity matters: disentangling services and disservices of ant communities driving yield in tropical agroecosystems. Proceedings of the Royal Society $B$ Vol. 281: 20132144; http://dx.doi.org/10.1098/rspb.2013.2144.

Maas B, Karp DS, Bumrungsri S, Darras K, Gonthier D, Huang JCC, Lindell CA, Maine JJ, Mestre L, Michel LN, Morrison EB, Perfecto I, Philpott SM, Sekercioglu CH, Silva RM, Taylor PJ, Tscharntke T, Van Bael S, Whelan CJ, Williams-Guillén K (2015): Bird and bat predation services in tropical forests and agroforestry landscapes. Biological Reviews: doi: 10.1111/ brv.12211.

Maas B, Tscharntke T, Saleh S, Dwi Putra D, Clough Y (2015): Avian species identity drives predation success in tropical cacao agroforestry. Journal of Applied Ecology 52: 735-743.

Tscharntke T, Milder JC, Schroth G, Clough Y, DeClerck F, Waldron A, Rice R, Ghazoul J (2015): Conserving biodiversity through certification of tropical agroforestry crops at local and landscape scales. Conservation Letters Vol. 8 (1): 14-23. OPEN ACCESS

Nagabhatla N, Padmanabhan M, Kühle P, Vishnudas S, Betz L, Niemeyer B (2015): LCLUC as an entry point for transdisciplinary research e Reflections from an agriculture land use change study in South Asia. Journal of Environmental Management Vol. 148: 42-52.

Motzke I, Tscharntke T, Wanger TC, Klein AM (2015): Pollination mitigates cucumber yield gaps more than pesticide and fertilizer use in tropical smallholder gardens. Journal of Applied Ecology Vol. 52 (1): 261-269. DOI: 10.1111/1365-2664.12357. 



\section{Cacao Research Activity at Agriculture Faculty of Tadulako University}

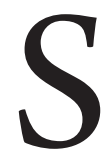

ulawesi Island is the largest cacao producer in Indonesia whereas Central Sulawesi Province is accounted as the largest producer among Provinces in Indonesia, produced 161,467 with cultivated cacao land are 291,445 ha (Directorate General of Estate Crops, 2015). The productivity of farms, in Central Sulawesi and others regions in Indonesia is however, continuously decreasing due to crop dieaseses and pests as well as adverse weather (Witjaksono \& Amin, 2016). On the other hand, the export of Indonesian cacao beans and intermediate products experienced massive growth. Hence, there is a strong need for further research on cacao and an improved understanding of how sustainable cacao production can be achieved to support export and domestic consumption on cacao, but also enhance benefits for cacao growers and the conservation of biodiversity and healthy ecosystems. Declining productivity is often related due an increased age of the cacao trees (which is up to 20 years in Central Sulawesi), to local farm management (shade cover and use of agrochemicals) that effects pathogens and pests on the farms, to effects of climate change and landscape management leading to the loss and

\section{Kegiatan Penelitian Kakao di Fakultas Pertanian Universitas Tadulako}

$\mathrm{P}$ ulau Sulawesi merupakan produsen kakao terbesar di Indonesia sedangkan Provinsi Sulawesi Tengah tercatat sebagai produsen terbesar di antara Provinsi di Indonesia, dengan produksi 161,467 dan luas perkebunan 291,445 ha (Direktorat Jenderal Perkebunan, 2015). Produktivitas di daerah ini dan juga wilayah lain di Indonesia dari tahun ke tahun umumnya menurun diakibatkan hama penyakit dan perubahan cuaca drastis (Witjaksono \& Amin, 2012).Di sisi lain, biji kakao dan produk antaranya yang diekspor dari Indonesia mengalami pertumbuhan yang tinggi. Oleh karena untuk menunjang produksi kakao berkelanjutan diperlukan riset yang kuat agar dapat mendukung ekspor dan konsumsi domestik kakao, yang memberi keuntungan bagi petani kakao dan konservasi keragaman hayati dan ekosistem yang sehat. Rendahnya produktivitas ini sering diakibatkan oleh umur tanaman kakao (mayoritas pohon sudah berusia 20 tahunan), keterampilan pengelolaan lahan (pohon naungan, dan pengunaan bahan kimiapertanian), yang mempengaruhi patogen dan hama di lahan pertanian, dampak perubahan iklim dan pengelolaan lansekap (bentang alam) yang menyebabkan hilangnya ataupun 
transformation of natural habitats, as well as to agronomy practices.

In cacao research, the Agriculture Faculty of Tadulako University is concentrated on few topics that cause yield losses caused by pathogens (mainly by Helopeltis spp., Phytophthora spp., and Vascular Strike Diseases (VSD)). These research activities are directed to develop bio-agent products to prevent and control pathogens. Various diseases caused by pathogens can be found in cacao. One major pathogen in the cultivation of the cocoa in Indonesia is black pod disease caused by Phytophthora palmivora. Black pod disease can infect the entire plant parts. Yield losses in the field ranged from $20-40 \%$ per year depending on few factors e.g. climates and farm management (Bowers et al., 2001). Major strategies to overcome the losses caused by the fungus are use of pesticides but this action can cause ecological problems such as lost of biodiversity and affect yield quality (Goulart et al., 2012). In thisfield, the activies of the faculty are concentrated on developing and promotingbiological agents to prevent or control this pathogen, such as demonstrated in the study of Pangeso et al. (2015) which aimed to provide information about the genetic diversity of cocoa clones in Central Sulawesi which can be used as a potential parent in crossing transformasi habitat alami, serta praktik agronomi itu sendiri.

Penelitian kakao, Fakultas Pertanian Universitas Tadulako berkonsentrasi pada beberapa topik terutama yang mengakibatkan kehilangan hasil oleh patogen (terutama oleh Helopeltis, Phytopthora dan penyakit). Penelitian ini diarahkan untuk mengembangkan produk bioagen untuk mencegah dan mengontrol patogen. Berbagai penyakit yang disebabkan oleh patogen dapat ditemukan di kakao, salah satu patogen utama dalam budidaya kakao di Indonesia adalah penyakit busuk/kanker yang disebabkan oleh Phytopthora palmivora. Penyakit busuk/ kanker ini dapat menginfeksi keseluruhan bahagian tanaman. Patogen ini menimbulkan efek negatif yaitu kehilangan hasil panen berkisar antara $20-40 \%$ per tahun tergantung pada beberapa faktor lainnya misalnya iklim dan manajemen lahan. Strategi utama untuk mengatasi kerugian yang disebabkan oleh jamur biasanya mengunakan pestisida tapi tindakan ini akan menimbulkan masalah ekologi dan mempengaruhi kualitas hasil panen. Pada topik ini, Fakultas lebih berkonsentrasi pada mencari agen biologis untuk mencegah atau mengendalikan patogen ini, seperti studi yang dilakukan oleh Panggeso dkk., (2015) yang bertujuan untuk memberikan informasi tentang keanekaragaman genetik klon kakao di 
process to achieve high yielding and resistant cocoa progeny against fruit rot disease caused by $P$. palmivora. Biological pest control receives more attention because of increasing public awareness of the multiple risks associated to side effect of pesticides and other agrochemicals used in cacao farms (e.g. fertilizer, fungizides, and herbizides). Besides the black pod disease that cause yield losses, the faculty also invests on studying Helopeltis spp. This research was aiming to develop biocontrol agents from entomopahtogenic fungi of Helopeltis spp. such as shown in the study of Pasaru et al. (2014).

\section{6}

\section{Produce good seeds through}

tissue culture, somatic embryo, and produce new clones of cacao, management plant rhizosphere, marketing, and capacity building offarmers are also the research concerns of the Faculty of Agriculture.
Sulawesi Tengah yang dapat digunakan sebagai induk yang yang dapat menghasilkan klon yang berproduksi tinggi dan tahan terhadap penyakit busuk buah yang disebabkan oleh Phytopthora palmivora. Pengendalian hama biologis mendapatkan perhatian lebih serius seiring dengan meningkatnya kesadaran masyarakat tentang bahaya efek samping pestisida kimia. Selain penyakit busuk buah yang menyebabkan kehilangan panen hasil yang tinggi, Fakultas juga berinventasi pada penelitian hama Helopeltis spp. Topik penelitian misalnya bertujuan untuk mengembangkan agen biokontrol dari jamur entomopahtogenic dari Helopeltis spp. seperti publikasi oleh Pasaru $d k k .$, (2014).

\section{6}

Menghasilkan bibit yang bagus melalui kultur jaringan, embrio somatik, dan menghasilkan klon kakao baru, manajemen rizosfir tanaman kakao, dan pemasaran dan peningkatan kapasitas petani juga merupakan bidang penelitian Fakultas Pertanian. 



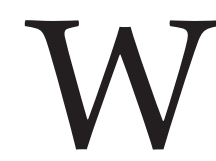

e thank all the local farmers and field assistants to give permission to conduct field research in their area, for their extraordinary commitment, hard work and good cooperation in the field. We also thank all cacao farmers who supported our research in Napu (Pak Ahmad, Pak Banti, Pak Bolai, Papa Ciko and Ciko, Pak Dedi, Pak Deni, Pak Dewa, Papa Jem, Papa Ain, Pak Main, Pak Ponedi, Roby, Pak, S. Limba, Pak Timotius, Pak Toni and Pak Walib) and local helpers who assisted us during the fieldwork for this thesis. Without the help and support, this study would not have been possible.

I, Bea Maas, would like to thank the research team in the field ("team chocolate") for their extraordinary commitment and hard work they provided during our research. I thank Edi who for his work as head assistant and for the great job he did. Opu, Papa Ifer, Sissi, Kiki and Sinto: thank you for all the hard work that you give and help with the study. Pak Dadang, I thank you very much for your help and support ami berterima kasih kepada semua
petani lokal dan asisten lapangan
yang sudah memberikan izin untuk melakukan penelitian lapangan di daerah mereka, atas komitmen mereka yang luar biasa, kerja keras dan kerja sama yang baik di lapangan. Kami juga berterima kasih kepada semua petani kakao yang mendukung penelitian kami di Napu (Pak Ahmad, Pak Banti, Pak Bolai, Papa Ciko dan Ciko, Pak Dedi, Pak Deni, Pak Dewa, Papa Jem, Papa Ain, Pak Main, Pak Ponedi, Roby, Pak S. Limba, Pak Timotius, Pak Toni dan Pak Walib) dan asisten- asisten lokal yang membantu kami selama penelitian di lapangan untuk tesis ini. Tanpa bantuan dan dukungan, penelitian ini tidak akan berjalan lancar.

Saya, Bea Maas, ingin berterima kasih pada tim penelitian di lapangan ("tim coklat") atas komitmen dan kerja keras mereka yang luar biasa di lapangan di Napu. Saya berterima kasih kepada Edi yang bersedia menjadi koordinator tim asisten dan untuk kerja hebat yang dia lakukan. Opu, Papa Ifer, Sissi, Kiki dan Sinto: terima kasih untuk semua kerja keras yang Anda berikan dan bantuan dengan penelitian ini. 
and everything you taught me about bird identification. I also thank everyone in Napu that helped me to develop the infrastructure to conduct this research. In this case, thanks to Idris Tinulele, Farly and Ibu Dorte. I thank Mama Nela who has given great support in Napu and helped me with so many open questions during the study period.

We thank Asmar, Putu and Anto for their help with the research of insects in the field. I would also like to thank Sony and Wandi, who often help me with the experimental exclosure experiments. In this regard, I also want to thank my colleagues Dr. Mark Adams and Dr. Arno Wielgoss to share their knowledge of exclosure experiments and insect identification. I am grateful to all those who provide assistance in the field and during our study period.

Our thanks goes to Ilfianti Kasmudin, who always provided assistance and support in both the CTFM Office in Palu (UNTAD Campus),
Pak Dadang, saya ucapkan terima kasih banyak atas bantuan dan dukungan dan semua yang Anda ajarkan kepada saya tentang identifikasi burung. Saya juga berterima kasih kepada semua orang di Napu yang membantu saya untuk mengembangkan infrastruktur untuk melakukan penelitian ini. Dalam hal ini, terima kasih kepada Idris Tinulele, Farly dan Ibu Dorte. Saya berterima kasih kepada Mama Nela yang telah memberikan dukungan yang sangat besar selama saya di Napu dan membantu saya dengan begitu banyak pertanyaan terbuka selama periode penelitian.

Kami berterima kasih kepada Asmar, Putu dan Anto atas bantuan mereka saat penelitian serangga di lapangan. Saya juga berterima kasih kepada Sony dan Wandi yang sering membantu saya dengan eksperimen "exclosure" di Napu. Dalam kesempatan ini, saya juga ingin berterima kasih kepada rekan-rekan saya Dr. Mark Adams dan Dr. Arno Wielgoss yang sudah berbagi pengetahuan mereka tentang eksperimen "exclosure" dan identifikasi serangga. Saya berterima kasih kepada semua orang yang memberikan bantuan di lapangan dan selama penelitian kami berlangsung.

Kami berterima kasih kepada Ilfianti Kasmudin, yang selalu memberikan bantuan dan dukungan baik di Kantor CTFM di Palu (Kampus UNTAD), 
on in the field in Napu, as well as for data entry and the translation of several documents. Ira Demita also helped us to enter large amounts of data, for which I am very grateful.

This work will also not be possible without the great support that we get from different offices in Palu and Bogor. First of all, we would like to thank our colleague Dr. Shahabuddin Saleh to support this research and provide very helpful information on work with students, as well as helping me to organize a presentation in Palu. Ilfianti Kasmudin help me with all kinds of administrative work, including the organization of research permits, field assistant salary, entry of data and transport equipment of our research in Palu and Napu and we are grateful for the tremendous support this. I would like to thank Dr. Aiyen Tjoa very helpful in many ways especially in the high last period of my research and gave me a great chance to give my work to young scientists and the public.

We thank the many people who have helped from the University Tadulako and the city of Palu (District of North Lore Lindu), the National Park office (Department of Forestry) and RISTEK/ di lapangan di Napu dan juga untuk entri data penelitian ini dan penerjemahan beberapa dokumen. Ira Demita juga membantu memasukkan sejumlah besar data kami, untuk itu saya sangat berterima kasih.

Karya ini juga tidak akan mungkin terjadi tanpa dukungan besar yang kami dapatkan dari berbagai instansi di Palu dan Bogor. Pertamatama, kami ingin berterima kasih kepada rekan kami Dr. Shahabuddin Saleh yang sudah mendukung penelitian ini dan memberikan informasi yang sangat membantu mengenai bekerja dengan mahasiswa, serta membantu saya untuk mengatur presentasi di Palu. Ilfianti Kasmudin membantu saya dengan semua jenis pekerjaan administratif, termasuk organisasi izin penelitian, gaji asisten lapangan, entri data dan transportasi peralatan penelitian kami di Palu dan Napu dan kami berterima kasih atas dukungan yang luar biasa ini. Saya ingin berterima kasih kepada Dr. Aiyen Tjoa yang sangat membantu dalam banyak hal terlebih dalam periode terakhir penelitian saya dan memberi saya peluang luar biasa untuk memberikan hasil kerja saya untuk ilmuwan muda dan masyarakat.

Kami berterima kasih pada banyak pihak yang telah membantu dan mendukung penelitian kami dari Universitas Tadulako dan kota Palu (Kecamatan Lore Lindu Utara), kantor Taman 
FRP (Jakarta) and supported our research. The drivers of our team (Sir Alex, Mr. Gauk and Mr. Baso) receive special thanks from us because it has been helpful in terms of equipment and transport.

We also thank Lya and Dewi for their support with my license renewal in Jakarta. In addition, we would like to thank Dr. Dewi Malia Prawiradilaga of Office LIPI in Cibinong (Bogor) to support our work (especially by providing the metal rings for bird censuses) as well as for an interesting and useful discussion that we had about the study of birds in Indonesia. I thank BirdLife Indonesia (Burung Indonesia) for giving me the opportunity to present the results of our research community to young scientists in Bogor. I am also grateful to the bird research institutions in Germany (Dr. Olaf Geiter; Institut für Vogelforschung Helgoland) and Austria (Mag. Matthias Schmidt, Auring Research Station) and Dr. Matthias Waltert to share their knowledge and their equipment with me for support study bird communities in Napu. The support of all these institutions significantly contributed to this research project.
Nasional (Departemen Kehutanan) dan RISTEK (Jakarta). Sopir-sopir tim kami (Pak Alex, Pak Gauk dan Pak Baso) mendapatkan ucapan terima kasih khusus dari kami karena telah membantu dalam hal peralatan dan transportasi.

Kami juga berterima kasih pada Lya dan Dewi atas dukungannya dalam perpanjangan izin saya di Jakarta. Selain itu, kami ingin berterima kasih kepada Dr. Dewi Malia Prawiradilaga dari Kantor LIPI di Cibinong (Bogor) untuk mendukung pekerjaan kami (terutama dengan memberikan cincin logam untuk sensus burung) serta untuk diskusi yang menarik dan bermanfaat tentang penelitian burung di Indonesia. Saya berterima kasih kepada BirdLife Indonesia (Burung Indonesia) karena telah memberi saya kesempatan untuk mempresentasikan hasil penelitian kami ke komunitas ilmuwan muda di Bogor. Saya juga berterima kasih kepada lembaga-lembaga penelitian burung di Jerman (Dr. Olaf Geiter; Institut für Vogelforschung di Helgoland) dan Austria (Mag. Matthias Schmidt, Stasiun Penelitian Auring) serta Dr. Matthias Waltert yang sudah berbagi pengetahuan dan peralatan mereka dengan saya untuk mendukung penelitian komunitas burung di Napu. Dukungan dari semua lembaga tersebut sangat berarti untuk proyek penelitian ini. 
I am grateful to my supervisors in Göttingen, Prof. Dr. Teja Tscharntke and PD Dr. Yann Clough to help me with the research project as a whole and for all the valuable input they provide to the scientific manuscripts. Moreover, I am grateful to Wolfram Lorenz to help me with the administration and organization of work in the North since 2008.

This research project was partially funded by a scholarship from the German National Academic Foundation (Studienstiftung des deutschen Volkes) and benefits from financial support from the German Science Foundation (DFG aid as a CL- 474 / 1-1 to Dr Yann Clough). The cost of printing the book was partly financed by the prize money of a 'Thomas. H. Kunz' award to Dr. Bea Maas, received at the 3rd Berlin Bat Meeting in Berlin (March 2013).

For this book, I would like to thank the co-authors. Each of members had played their roles nicely and at the end we can present this book to public proudly in two languages. At last but not least I would like to thank Tadulako University to fund the printing of this book.
Saya berterima kasih kepada supervisor saya di Goettingen, Prof. Dr. Teja Tscharntke dan PD Dr. Yann Clough yang membantu saya dengan proyek penelitian secara keseluruhan serta untuk semua masukan berharga yang mereka berikan pada naskah ilmiah saya. Selain itu, saya berterima kasih kepada Wolfram Lorenz untuk membantu saya dengan administrasi dan organisasi kerja di Utara sejak tahun 2008.

Proyek penelitian ini sebagian didanai oleh beasiswa dari Yayasan Akademi Nasional Jerman (Studienstiftung des deutschen Volkes) dan memperoleh dari dukungan keuangan dari Jerman Science Foundation (bantuan DFG sebagai CL-474/1-1 ke Dr Yann Clough). Biaya pencetakan buku ini sebagian didapatkan dari uang hadiah penghargaan 'Thomas. $\mathrm{H}$. Kunz' untuk Dr. Bea Maas yang diterima pada konferensi '3rd Berlin Bat Meeting' (Maret 2013).

Untuk buku ini, saya berterima kasih kepada seluruh penulis pendamping. Setiap anggota mempunyai peran masing-masing sehingga buku dwi-bahasa ini dapat diselesaikan dan dibaca publik. Akhirnya tanpa mengurangi arti saya berterima kasih kepada Universitas Tadulako yang membiayai pencetakan buku ini. 

Achard, F., Eva, H. D., Stibig, H. J., Mayaux, P., Gallego, J., Richards, T. and Malingreau, J. P. (2002) Determination of deforestation rates of the world's humid tropical forests. Science 297: 999-1002.

Akiyama, T. and Nishio, A. (1996). Indonesia's cacao boom: hands-off policy encourages smallholder dynamism. World Bank Policy Research Working Paper, 1580.

Bommarco, R., Kleijn, D., \& Potts, S. G. (2013). Ecological intensification: harnessing ecosystem services for food security. Trends in ecology \& evolution, 28: 230-238.

Clough, Y., Barkmann, J., Juhrbandt, J., Kessler, M., Wanger, T.C., Anshary, A., et al. (2011). Combining high biodiversity with high yields in tropical agroforests. PNAS, 108, 8311-8316.

Clough, Y., Dwi Putra, D., Pitopang, R. \& Tscharntke, T. (2009). Local and landscape factors determine functional bird diversity in Indonesian cacao agroforestry. Biol. Conserv., 142, 1032-1041.

Clough, Y., Faust, H. and Tscharntke, T. (2009) Cacao boom and bust: sustainability of agroforests and opportunities for biodiversity conservation. Conservation Letters, 2: 197-205.

Daily, G. C. (2001) Ecological forecasts. Nature 411: 245-245.

Directorate General of Tree Crops, 2015. Tree crop estate statistic of Indonesia 2014-2016. Ministry of Agriculture of Indonesia

Foley, J. A., Ramankutty, N., Brauman, K. A., Cassidy, E. S., Gerber, J. S., Johnston, M., Mueller, N.D., O’Connell, C., Ray, D.K., West, P.C., Balzer, C., Bennett, E.M., Carpenter, S.R., Hill, J., Monfreda, C., Polasky, S., Rockström, J., Sheehan, J., Siebert, S., Tilman, D.and Zaks, D. P. (2011). Solutions for a cultivated planet. Nature, 478: 337-342.

Jose, S. (2009) Agroforestry for ecosystem services and environmental benefits: an overview. Agroforestry Systems 76: 1-10.

Kalka, M.B., Smith, A.R. and Kalko, E.K.V. (2008). Bats limit arthropods and herbivory in a tropical forest. Science, 320: 71-71.

Karp, D.S., Mendenhall, C.D., Sandí, R.F., Chaumont, N., Ehrlich, P.R., Hadly, E.A., \& Daily, G.C. (2013) Forest bolsters bird abundance, pest control and coffee yield. Ecology Letters, 16, 1339-1347. 
Keinan, A. and Clark, A. G. (2012) Recent explosive human population growth has resulted in an excess of rare genetic variants. Science 336: 740-743.

Lawton, J. H., Bignell, D. E., Bolton, B., Bloemers, G. F., Eggleton, P., Hammond, P. M., Hodda, M., Holt, R. D., Larsenk, T. B., Mawdsley, N. A., Stork, N. E., Srivastava, D. S. and Watt, A. D. (1998) Biodiversity inventories, indicator taxa and effects of habitat modification in tropical forest. Nature 391: 72-76.

Lee, T.M., Sodhi, N.S., Prawiradilaga, D.M., 2007. The importance of protected areas for the forest and endemic avifauna of Sulawesi (Indonesia). Ecol. Appl. 17, 1727-1741.

Maas, B., Putra, D.D., Waltert, M., Clough, Y., Tscharntke, T. \& Schulze, C.H. (2009) Six years of habitat modification in a tropical rainforest margin of Indonesia do not affect bird diversity but endemic forest species. Biological Conservation, 142, 2665-2671.

Maas, B., Clough, Y., \& Tscharntke, T. (2013) Bats and birds increase crop yield in tropical agroforestry landscapes. Ecology Letters, 16, 1480-1487.

Maas B, Karp DS, Bumrungsri S, Darras K, Gonthier D, Huang JCC, Lindell CA, Maine JJ, Mestre L, Michel LN, Morrison EB, Perfecto I, Philpott SM, Sekercioglu CH, Silva RM, Taylor PJ, Tscharntke T, Van Bael S, Whelan CJ, Williams-Guillén K (2015a): Bird And Bat Predation Services In Tropical Forests And Agroforestry Landscapes. Biological Reviews 91: 1081-1101.

Maas B, Tscharntke T, Saleh S, Dwi Putra D, Clough Y (2015b): Avian Species Identity Drives Predation Success In Tropical Cacao Agroforestry. Journal of Applied Ecology 52: 735-743.

Millennium Ecosystem Assessment. (2005). Ecosystems and human well-being: Synthesis. Island Press, Washington, DC.

Mols, C.M., \& Visser, M.E. (2002) Great tits can reduce caterpillar damage in apple orchards. Journal of Applied Ecology, 39, 888-899.

Morrison, E.B. \& Lindell, C.A. (2012). Birds and bats reduce insect biomass and leaf damage in tropical forest restoration sites. Ecol. Appl., 22, 1526-1534.

Moser, G., Leuschner, C., Hertel, D., Hölscher, D., Köhler, M., Leitner, D. Michalzik, B., Prihastanti, E., Tjitrosemito, S. and Schwendenmann, L. (2010) Response of cacao trees (Theobroma cacao) to a 13-month desiccation period in Sulawesi, Indonesia. Agroforestry Systems 79: 171-187. 
Panggeso J., Anshary A., Samuddin S., and Basri Z. 2015. Genetic diversity of different cocoa clones by RAPD (Random Amplified Polymorphic DNA) markers. Int. J. Curr. Res. Aca. Rev. 3 (3); pp 195-201

Pasaru F., Anshary A., Kuswinanti T., Mahudz and Shabuddin. 2014. Prospective of entomopathogenic fungi associated with Helopeltis spp. (Hemipter: Miridae) on cacao plantation. Int. J. Curr. Res. Aca. Rev. 2 (11); pp 227-234

Schroth, G. (Ed.). (2004) Agroforestry and biodiversity conservation in tropical landscapes. Island Press. Stattersfield, A. J., Crosby, M. J., Long, A. J. \& Wege, D. C., 1998. Endemic Bird Areas of the World: Priorities for Biodiversity Conservation BirdLife International, Cambridge, UK.

Tilman, D., Cassman, K. G., Matson, P. A., Naylor, R. and Polasky, S. (2002) Agricultural sustainability and intensive production practices. Nature 418: 671-677.

Tscharntke, T., Clough, Y., Bhagwat, S.A., Buchori, D., Faust, H., Hertel, D., et al. (2011). Multifunctional shade-tree management in tropical agroforestry landscapes - a review. J. Appl. Ecol., 48, 619-629.

Tscharntke, T., Clough, Y., Wanger, T.C., Jackson, L., Motzke, I., Perfecto, I., Vandermeer, J. and Whitbread, A. (2012) Global food security, biodiversity conservation and the future of agricultural intensification. Biological Conservation, 151: 53-59.

Wall Street Journal (2011) Indonesia, Ghana may Fill Cacao Void. Wall Street Journal, 2011, April 06, pp.n/a.

Wielgoss, A., Clough, Y., Fiala, B., Rumede, A. \& Tscharntke, T. (2012). A minor pest reduces yield losses by a major pest: plant-mediated herbivore interactions in Indonesian cacao. J. Appl. Ecol., 49, 465-473.

Wielgoss A, Tscharntke T, Rumede A, Fiala B, Seidel H, Shahabuddin S, Clough Y (2014) Interaction complexity matters: disentangling services and disservices of ant communities driving yield in tropical agroecosystems. Proceedings of the Royal Society B: Biological Sciences 281 (1775):20132144

Williams-Guillén, K., Perfecto, I. and Vandermeer, J. (2008). Bats limit insects in a neotropical agroforestry system. Science, 320: 70-70. 


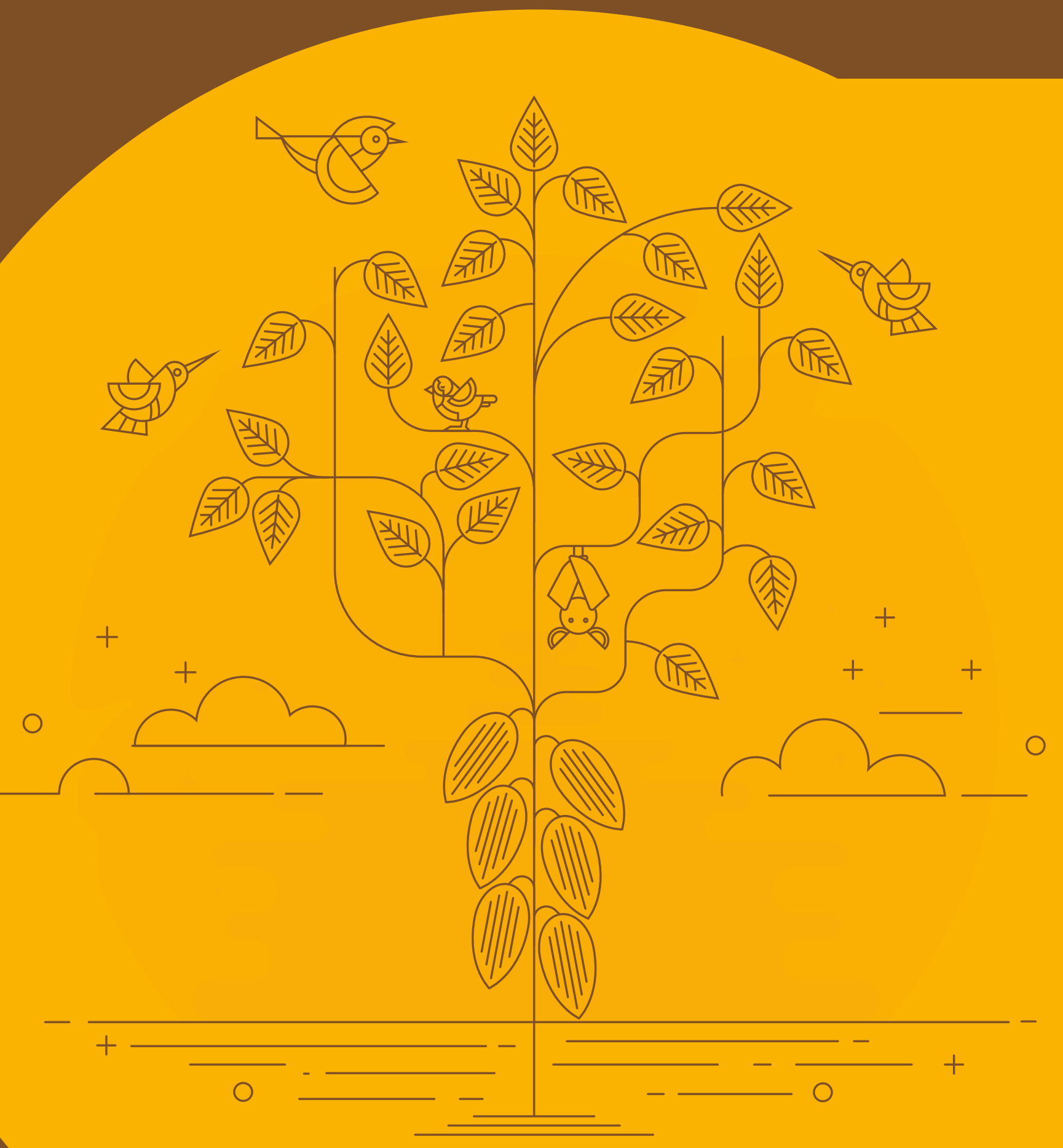




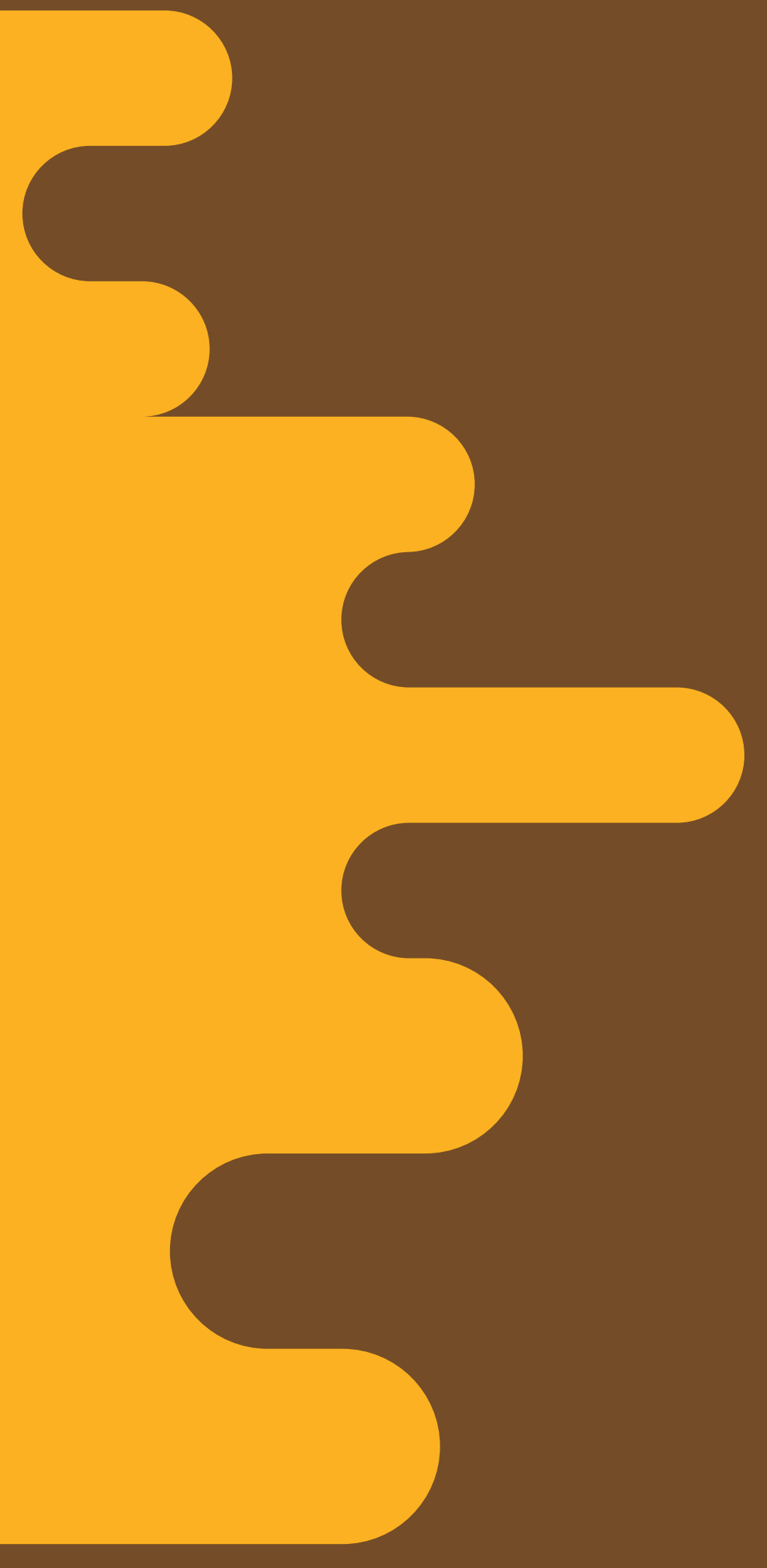


Cacao agroforestry systems are common in Indonesia, but differences in local management affect biodiversity and related ecosystem services. Importantly, birds and bats alike strongly contribute to biological pest control in cacao, thereby promoting yields and sustainable farming. Our findings from many years of ecological field research, in close collaboration with Indonesian cacao farmers, are summarized and discussed in this bilingual book, written in both English and Indonesian. It is designed to communicate scientific information as well as to facilitate transdisciplinary discussions and more biodiversity-friendly management in tropical agroforestry systems.

We consider this book as a tool to improve the collaboration of local communities, farmers and scientists, as well as to improve the application of scientific knowledge in agricultural practice particularly in tropical land use areas.

Bea Maas, the first author of this book, is postdoctoral researcher at the University of Vienna (Austria), working in the fields of biology, ecology and conservation. She conducted the research and workshops presented here in close collaboration and with support from the University of Göttingen (Germany) and the University of Tadulako (Indonesia).

Sistem agroforestri kakao adalah hal umum di Indonesia, tetapi perbedaan pengelolaan setempat akan mempengaruhi keanekaragaman hayati dan layanan ekosistem. Terutama, burung dan kelelawar sama-sama memberikan kontribusi tinggi pada pengendalian hama biologis di kakao, sehingga dapat meningkatkan hasil panen dan pertanian yang berkelanjutan. Temuan kami dari penelitian lapangan ekologi bertahun-tahun, yang bekerjasama erat dengan petani kakao Indonesia, dirangkum dan dibahas dalam buku bilingual ini, tertulis dalam bahasa Inggris dan bahasa Indonesia. Buku ini dirancang untuk mengkomunikasikan informasi ilmiah dan juga untuk memfasilitasi diskusi transdisipliner dan pengelolaan keanekaragaman hayati yang ramah pada sistem agroforestri tropis.

Kami menganggap buku ini sebagai alat untuk meningkatkan kolaborasi masyarakat lokal, petani dan ilmuwan, serta untuk meningkatkan penerapan pengetahuan ilmiah dalam praktik pertanian terutama di wilayah penggunaan lahan tropis.

Bea Maas, penulis pertama buku ini, adalah peneliti postdoctoral di Universitas Wina (Austria), bekerja di bidang biologi, ekologi dan konservasi. Dia melakukan penelitian dan lokakarya yang disampaikan dalam buku ini dengan kerjasama yang erat dan dukungan dari Universitas Göttingen (Jerman) dan Universitas Tadulako (Indonesia). 